UNIVERSIDADE DE SÃO PAULO

INSTITUTO DE GEOCIÊNCIAS

\title{
ÍONS METÁLICOS (Al, Fe, Mn e Pb) ASSOCIADOS A ATERROS (SANITÁRIO E INDUSTRIAL) NO MUNICÍPIO DE TREMEMBÉ/SP
}

Claudia Lucia de Moura

Orientador: Prof. Dr. Raphael Hypolito

TESE DE DOUTORADO

Programa de Pós-Graduação em Hidrogeologia e Meio Ambiente

São Paulo

2008 


\section{SUMÁRIO}

Lista de Figuras. ix

Lista de Tabelas. $\mathrm{xi}$

Lista de Quadros. xiv

Resumo. .$x V$

Abstract xii

\section{CAPÍTULO I}

1. Introdução

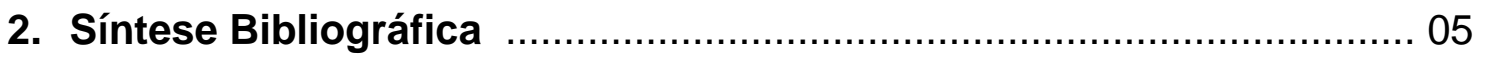

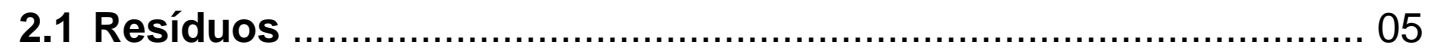

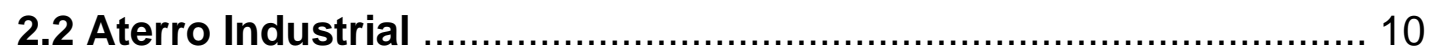

2.3 Tratamento de Resíduos Perigosos ........................................... 13

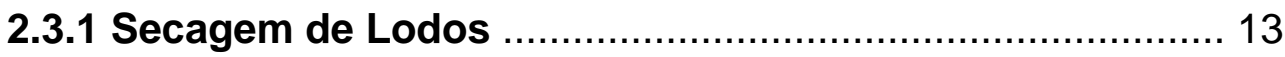

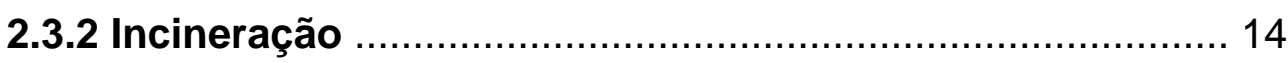

2.3.3 Estabilização e Solidificação ........................................... 16

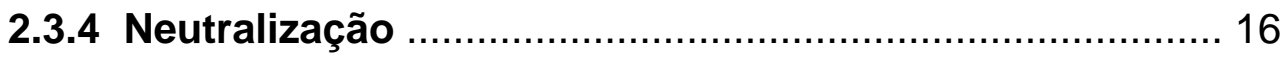

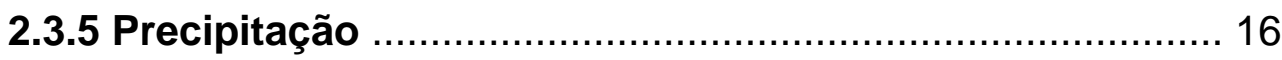

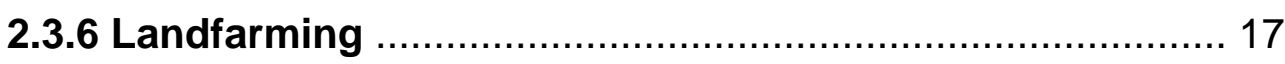

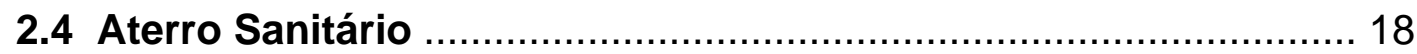

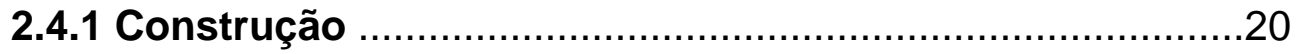




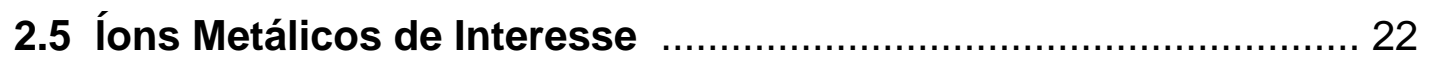

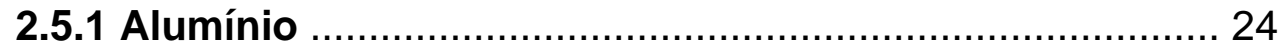

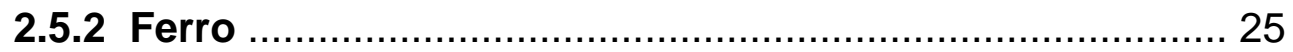

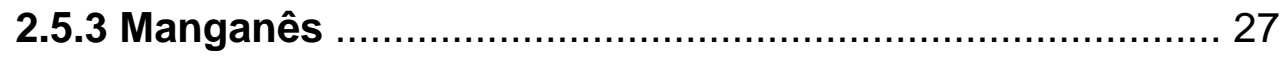

2.5.4 Chumbo

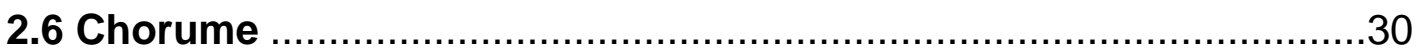

2.7 Técnicas empregadas no Tratamento de Chorume ……............... 34

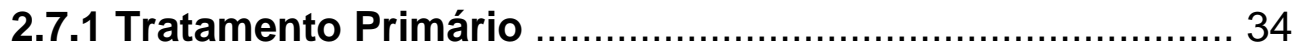

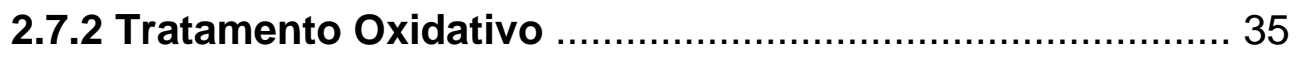

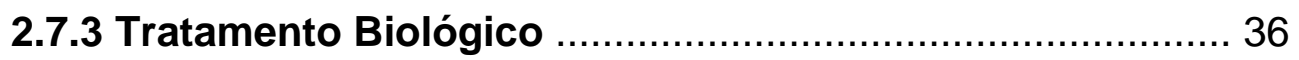

2.7.4 Separação com Membranas …………………............... 37

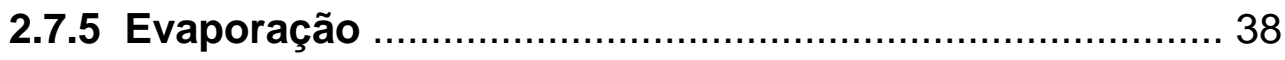

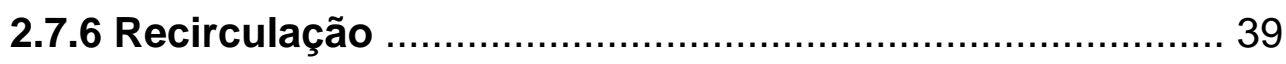

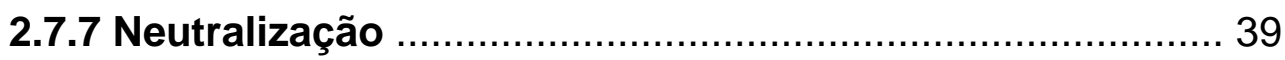

2.7.8 Tratamento Eletroquímico ………………….................. 40

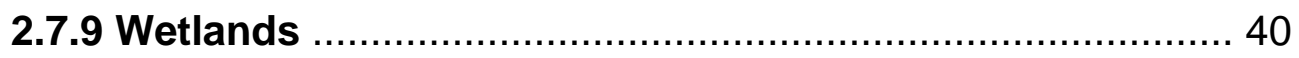

2.7.10 Remoção de Metais Pesados ......................................... 42

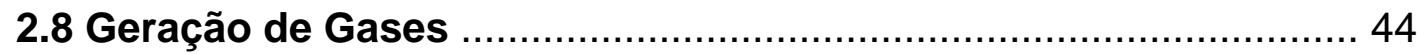

\section{CAPÍTULO II}

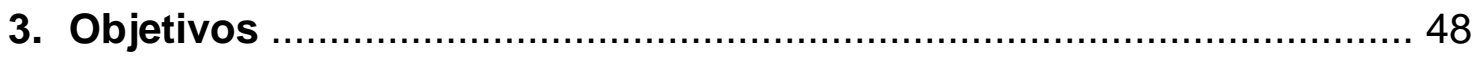

4. Localização e Caracterização da Área de Estudo ………………........ 49

4.1 Localização e Acessos ..................................................... 49

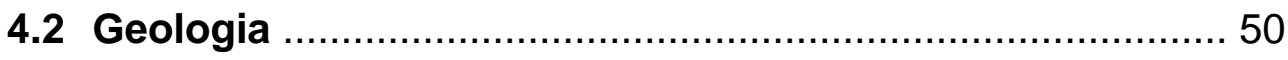

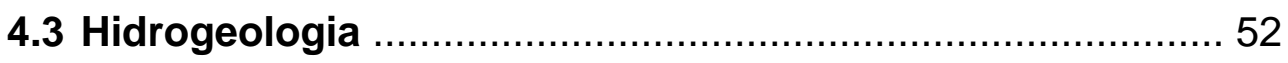

4.4 Vegetação, Pedologia e Clima …….................................... 53 


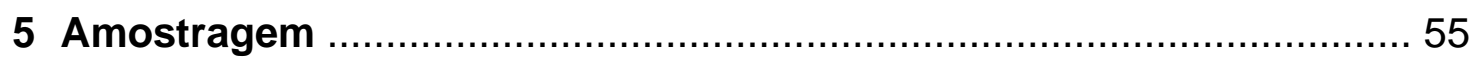

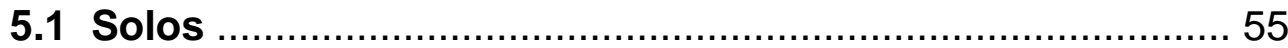

5.2 Solos/Sedimentos ................................................ 56

5.3 Sedimento de Fundo ............................................... 56

5.4 Águas Subterrâneas ................................................. 56

5.5 Águas Superficiais ............................................. 58

6 Parâmetros Físico-Químicos Medidos em Campo .......................... 61

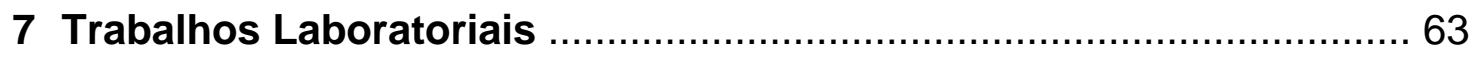

7.1 Análises Granulométricas ................................... 64

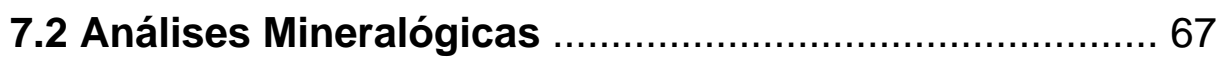

7.3 Fluorescência de Raios X ..................................... 69

7.4 Extrações Químicas ........................................... 70

7.5 Análises Químicas ................................................ 71

CAPITULO III

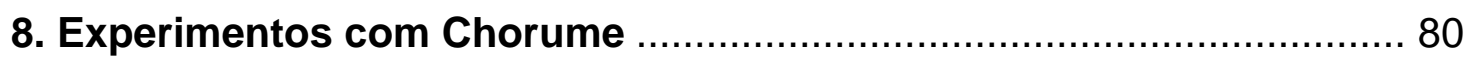

8.1 Coleta e dados Analíticos do Chorume ..................... 87

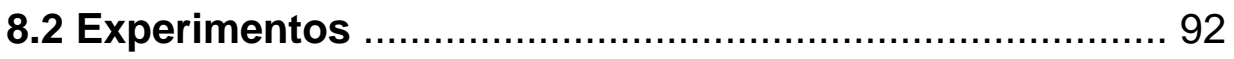

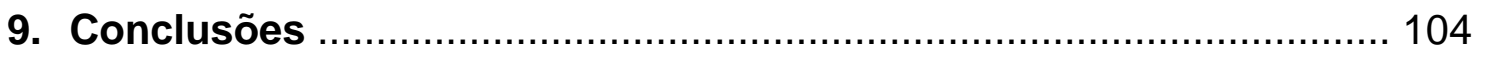

\section{CAPÍTULO IV}

10. Referências Bibliográficas 


\section{LISTA DE FIGURAS}

2.1 - Foto aérea do aterro industrial; parte do conjunto de Aterros que compõem a área em estudo 12

2.2 - Foto do Aterro Sanitário (A), construído acima do terreno, na forma de pirâmide 21

2.3 - Foto do Aterro Sanitário (C) construído abaixo do Terreno 22

2.4 - Diagrama de concentração de alumínio em função dos valores de pH 25

2.5 - Diagrama de concentração de chumbo em função dos valores de pH 29

2.6 - Sistema de tratamento do chorume, realizado pela Empresa onde estão localizados os Aterros estudados 33

4.1 - Acessos da área de estudos no Município de Tremembé/SP 49

4.2 - Geologia da área de estudos 51

4.3 - Variação da média mensal da pluviometria da área de estudo 53

5.1 - Amostragem de solo do entorno dos Aterros 55

5.2 - Foto do poço de monitoramento e amostragem de água subterrânea com auxílio do amostrador do tipo bailer 57

5.3 - Amostragem de água superficial do afluente do Rio Serragem que sofre interferência direta dos Aterros 58

5.4 - Pontos de amostragem e fluxo das águas subterrâneas 60

7.1 - Diagrama triangular do Departamento de Agricultura dos Estados Unidos para classificação de solos 65

7.2 - Diagrama triangular de Shepard (1954) 66

7.3 - Difratogramas das análises mineralógicas 68

7.4 - Diagramas de $\mathrm{pH}=\mathrm{f}(\mathrm{Eh})$ de compostos de ferro e manganês à $25^{\circ} \mathrm{C}$ e 1 atm 
8.2 - Classificação da qualidade das águas utilizadas na agricultura 86

8.3 - Estocagem (a) e coleta (b) de amostras de chorume dos Aterros A, B e C 88

8.4 - Tratamento do chorume para eliminação da fração líquida 92

\section{LISTA DE TABELAS}

6.1 - Dados químicos e físico-químicos das águas subterrâneas da área dos Aterros $A, B, C$ e $D$ 61

6.2 - Dados químicos e físico-químicos das águas superficiais da área dos Aterros e entorno

7.1 - Resultados das determinações de CTC, pH e M.O. do solo, solo/sedimento e sedimento de fundo

7.2 - Análises granulométricas (\%) do solo segundo Departamento de Agricultura dos Estados Unidos e dos solo/sedimento e sedimento de fundo, segundo Shepard (1954)

7.3 - Resultados das análises mineralógicas do solo, solo/sedimento e sedimento de fundo por Difração de Raio $X$ 67

7.4 - Análises químicas dos constituintes maiores (\%) do solo, solo/sedimento e sedimento de fundo, obtidas através da Espectrometria por Fluorescência de Raios $\mathrm{X}$

7.5 - Análise química dos elementos-traço $\left(\mathrm{mg} \mathrm{kg}^{-1}\right)$ do solo, solo/sedimento e sedimento de fundo, obtidas através da Espectrometria por Fluorescência de Raios $\mathrm{X}$.

7.6 - Resultados obtidos nas extrações $\left(\mathrm{mg} \mathrm{kg}^{-1}\right)$ de solo, solo/sedimento e sedimentos de fundo. 70

7.7 - Análises químicas de cátions $\left(\mathrm{mg} \mathrm{dm}^{-3}\right)$ das águas subterrâneas presentes na área dos Aterros. 
7.8 - Resultados das análises químicas de cátions $\left(\mathrm{mg} \mathrm{dm}^{-3}\right)$ das águas superficiais presentes na área dos Aterros e entorno 76

7.9 - Resultados dos ânions $\left(\mathrm{mg} \mathrm{dm}^{-3}\right)$ das análises químicas das águas subterrâneas presentes na área dos Aterros.

7.10 - Resultados dos ânions $\left(\mathrm{mg} \mathrm{dm}^{-3}\right)$ das análises químicas das águas superficiais presentes na área dos Aterros.

8.1 - Valores de pH e Eh (V) das amostras de chorumes I (Tremembé), II (Mauá) e III (Santo André) 90

8.2 - Dados analíticos ( $\mathrm{mg} \mathrm{dm}^{-3}$ ) dos chorumes brutos (I, II e III) e das lagoas de tratamento (II e III) coletados nos períodos seco e chuvoso 91

8.3 - Massa (g) dos resíduos do aquecimento de $3 \mathrm{~L}$ de chorume 93

8.4 - Estimativa da massa $(\mathrm{kg})$ calculada do resíduo do aquecimento de $20 \mathrm{~m}^{3}$ de chorume 93

8.5 - Porcentagens de eliminação da fração líquida do aquecimento dos chorumes 93

8.6 - Análises químicas dos constituintes maiores e dos elementos-traço $\left(\mathrm{mg} \mathrm{kg}^{-1}\right)$ do resíduo gerado no aquecimento dos chorumes. 95

8.7 - Resultados analíticos $\left(\mathrm{mg} \mathrm{dm}^{-3}\right.$ ) dos testes de solubilização com $\mathrm{H}_{2} \mathrm{O}$ dos resíduos obtidos no aquecimento dos chorumes 97

8.8 - Valores da razão de adsorção de sódio (SAR) das amostras secas e solubilizadas em $\mathrm{H}_{2} \mathrm{O}$ e $\mathrm{HCl}$, dos Aterros I, II e III 100

8.9 - Análises químicas dos constituintes maiores e elementos-traço $\left(\mathrm{mg} \mathrm{kg}^{-1}\right)$ do lodo gerado no tratamento do chorume (torta) do ATERRO II 101 8.10 - Resultados analíticos dos testes de solubilização com $\mathrm{H}_{2} \mathrm{O}\left(\mathrm{mg} \mathrm{dm}^{-3}\right)$ das tortas obtidas no Aterro II 101 


\section{LISTA DE QUADROS}

2.1 - Impactos ocorridos pelo descarte irregular de resíduos perigosos 06

2.2 - Quantidade coletada de resíduos sólidos urbanos no Brasil 08

2.3 - Quantidade coletada de resíduos industriais no ano de 2004 08

2.4 - Seleção de locais para implantação de aterros industriais 11

2.5 -Condições desejáveis e não desejáveis para construção de aterros sanitários 19

2.6 - Vantagens e desvantagens da utilização de aterros sanitários 20

2.7 - Chorume: principais íons e origens 31

2.8 - Composição básica de biogás produzido nos aterros sanitários 45

4.1 - Principais características dos aqüíferos locais 52

8.1 - Quantidade de nutrientes disponíveis no solo, em relação ao total presente 


\section{RESUMO}

Um dos grandes problemas das Metrópoles tem sido o descarte de resíduos sólidos. Em diversas situações aterros são selecionados como solução de melhor viabilidade para disposição final desses materiais que, na maioria das vezes, são agentes poluentes. Condições inadequadas de operação e conservação desses locais vêm acarretando inúmeros danos ao meio ambiente, em especial, nas áreas de seu entorno que, muitas vezes, possuem aglomerados residenciais.

Neste trabalho foram avaliadas condições ambientais mais significativas de uma área e de seu entorno onde se encontram instalados quatro Aterros, três Sanitários e um Industrial, localizados no Município de Tremembé/SP. Provavelmente como conseqüência do mau gerenciamento e descaso das atividades destes Aterros, eles têm sido alvo de inúmeras denúncias, uma vez que trazem grandes prejuízos à população vizinha.

Foram estudados os principais agentes poluidores com especial atenção ao comportamento dos íons metálicos alumínio, ferro, manganês e chumbo, em amostras de diferentes compartimentos - solo, solo/sedimento, sedimento de fundo e águas superficiais e subterrâneas.

As águas subterrâneas associadas aos Aterros Sanitários encontram-se comprometidas devido a altas concentrações dos íons estudados, cujo comportamento são, em alguns deles, regidos fundamentalmente pelos valores de $\mathrm{pH}$ e potencial óxido-redução. Este fato é motivo de grande preocupação, uma vez que na região a grande maioria da população faz uso de águas para consumo humano extraídas de poços do tipo cacimba, além de regas a hortas, dessedentação de animais e abastecimento de ranários por rios e lago.

Os dados analíticos das águas superficiais do Rio Serragem e seu afluente que limitam a área de estudo, também apresentaram valores superiores 
aos permitidos pelos órgãos oficiais para os íons ferro, alumínio e manganês, sempre ligados aos Aterros.

Comprovou-se que as características mineralógicas, granulométricas e capacidade de troca catiônica dos solos associados aos Aterros, não são adequadas para a retenção de íons metálicos. Por outro lado os dados de pH do solo $(\Delta \mathrm{pH})$ se mostram favoráveis aos fenômenos de adsorção iônica.

A geração de chorume é um dos principais passivos ambientais resultados das atividades dos aterros. No âmbito de sugerir idéias que minimizem os impactos produzidos pelo chorume, este trabalho propôs uma destinação mais apropriada para este efluente.

Foram realizados experimentos com chorumes dos três Aterros Sanitários estudados e também com chorume coletados no Município de Santo André e Mauá.

O trabalho permitiu afirmar que com a eliminação, por aquecimento, da fração líquida do chorume, resulta em um resíduo que tem seu transporte significativamente facilitado devido à redução em mais de 95\% de volume, além de apresentar-se rico em potássio, magnésio, cálcio, fósforo, manganês e ferro e cloretos que podem ser reaproveitado na agricultura, em especial no plantio resistente à teores mais elevados de sódio. 


\section{ABSTRACT}

A major problem of big cities have been the disposal of solid wastes. In several situations, landfills are selected as solution of better feasibility for final placement of such material that, in most cases, are pollutants. Inadequate conditions of operation and conservation of those locations are giving rise to numerous damage to the environment, in particular, in the surroundings areas that often have residential clusters.

In this work have been assessed the most significant environmental conditions in a particular area and its surroundings where were installed four landfills, three sanitaries and one industrial, located in the city of Tremembé / SP. Probably as a result of bad management and careless of these landfills, they have got many complaints, once is bringing on great damage to neighboring population.

Were studied the main pollutants with special attention to the behaviour of metal ions, aluminium, iron, manganese and lead on samples of different compartments - soil, sediment / soil, sediment of surface water and groundwater.

Groundwater associated with landfill are involved due to high concentrations of the studied ions, which behaviour are, in some of them, essentially governed by the values of $\mathrm{pH}$ and oxide-reduction potential. This fact is a reason of great concern, since in the region the vast majority of the population makes use of water, extract from production well, for human consumption, beyond frog farm.

The analytics data of the surface water of Serragem River and its stream limits the study field, also submitted values higher than those allowed by official bodies for ions iron, aluminium and manganese, always related to the landfills. 
It was proved that the mineral characteristics, size analysis and ability to cationic exchange from associated soils with landfills, are not suitable for the retention of metal ions. In the other hand, the data from $\mathrm{pH}$ soil $(\Delta \mathrm{pH})$ are favorable to the phenomena of lonic adsorption strength.

The generation of leachate is one of the main environmental liabilities results of the activities of landfills. With the idea to minimize the impact produced by leachate, this work propose a more appropriate destination for this effluent

Were carried out experiments with leachate of three studied landfills and also with collected leachate in Santo André and Mauá cities.

This work allowed to affirm that with the disposal, by heating the liquid part of the leachate, results in a residue that has its transport significantly facilitated due to the reduction in more than $95 \%$ of its volume, and also it performs rich in potassium, calcium, magnesium, phosphorus, iron, manganese and chlorides that can be reused in agriculture, in particular, plantation resistant to higher levels of sodium. 


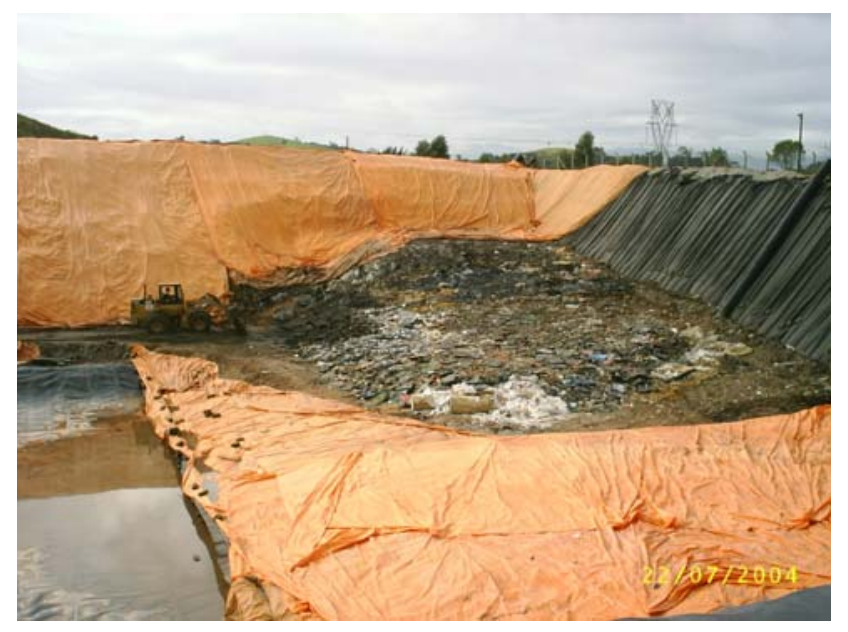

\section{CAPÍTULO I}
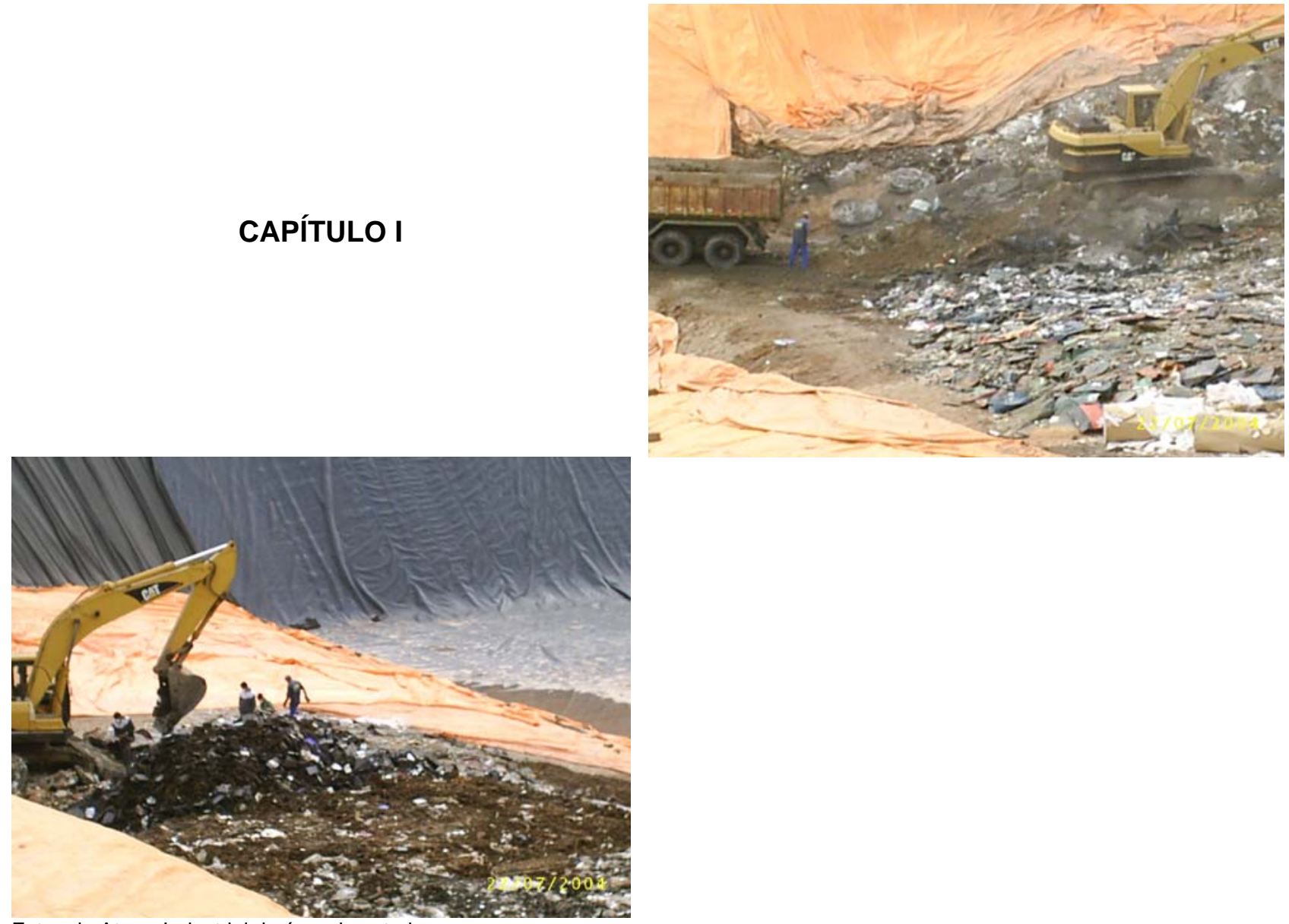

Fotos do Aterro Industrial da área de estudo 


\section{1 - INTRODUÇÃO}

O crescimento demasiado das sociedades de consumo, opostas ao desenvolvimento sustentável, tem contribuído de modo significativo para o aumento da produção de resíduos que, por muitos anos, deixaram de ser descartados em locais apropriados, formando ciclos de agressão ao meio ambiente.

Após a Revolução Industrial foi crescente o número de substâncias que surgiram acompanhando os desenvolvimentos econômicos, industriais e agrícolas de cada país (ARCURI \& FERNICOLA, 2003) e conseqüentemente o surgimento dos maiores passivos ambientais. Somente nos Estados Unidos a Environmental Protection Agency já havia listado, até o final de 1995, 40 mil locais de destinação final de resíduos perigosos, sendo que em $75 \%$ desses locais foram encontrados metais pesados.

Quando se trata de resíduos, o objetivo maior é a minimização destes, o que inclui sua eliminação ou redução ainda na fonte ou, caso sua geração não possa ser evitada, sua reciclagem, reutilização ou recuperação (STRAUS \& MENESES, 1994; RHYNER et al., 1995).

O tratamento do resíduo, segundo BATSTONE et al. (1989), também deve ser considerado como forma de minimização, uma vez que objetiva reduzir seu volume e/ou toxicidade.

CALDERONI (1998) também destaca alguns fatores fundamentais ao processo da reciclagem, como exaustão e custos crescentes de obtenção de matérias-primas, economia de energia, indisponibilidade e custo crescente dos aterros, transporte, poluição e prejuízos à saúde pública, bem como redução dos custos de produção.

A grande variedade de resíduos sólidos e semi-sólidos aliada à presença de substâncias potencialmente tóxicas requer exaustivos esforços no sentido de buscar soluções apropriadas para que não causem prejuízo à saúde 
pública e ao meio ambiente (OLIVEIRA et al., 2003). A disponibilidade de instalações adequadas para seu tratamento e disposição final é fator essencial para o êxito de qualquer sistema de controle ambiental (YAKOWITZ, 1985; WILSON \& FORESTER, 1987; BATSTONE et al., 1989; ANDERSSON, 1991; BALKAU, 1991).

A disposição final é um dos grandes problemas enfrentados pelas indústrias e órgãos governamentais. Em áreas de descartes, é muito comum constatar desequilíbrios entre substâncias nocivas percoladas no conjunto solo/aqüífero e a capacidade de auto-purificação dos sistemas ambientais (SCHIANETZ, 1999).

No Brasil, em 2004, estima-se geração de aproximadamente 163.000 t/dia de resíduos sólidos urbanos (ABRELPE, 2004) sendo 26 milhões de t/ano industriais. Somente no Estado de São Paulo, 2\% são referentes a resíduos perigosos (CETESB, 1996). Segundo a Associação Brasileira de Empresas de Limpeza Pública e Resíduos Especiais (ABRELPE op. cit., 2004), estima-se que quase 8000 locais de disposição inadequada estão contaminando o solo e o lençol freático.

Segundo a Associação Brasileira de Normas Técnicas - ABNT (NBR 10 004, 2004) os resíduos sólidos passaram a ser classificados em dois grupos: classe I (perigosos) e classe II (não perigosos), esta última subdividida em classe IIA (não inertes) e classe IIB (inertes).

A preocupação do monitoramento em áreas destinadas à disposição final desses materiais deve ter igual importância independente da classificação; parte dos resíduos perigosos gerados no Brasil continua sendo disposta de forma incorreta, muitos deles misturados aos não perigosos e encaminhados para aterros impróprios.

No Brasil, os aterros ainda são o destino mais comum de resíduos, devido o baixo custo (TENÓRIO \& ESPINOSA, 2004). Tanto o aterro sanitário destinado aos não perigosos como os industriais destinados aos perigosos, quando construídos e gerenciados de forma adequada são boas soluções. A longo 
prazo, contudo, podem, além de gerar complicações ambientais não servirem de incentivos para que as industrias e os municípios invistam mais em reciclagem e/ou minimização de resíduos.

Mesmo quando bem gerenciados, os aterros produzem ainda 0 chorume, um líquido escuro e turvo, de odor extremamente desagradável. Ele é um efluente quimicamente complexo, com características particulares para cada aterro, por isso é fundamental que se façam avaliações rigorosas e adequadas para o tipo de tratamento que se enquadra às suas características, que incluem processos físicos, químicos e biológicos.

Selecionou-se para a área de estudo, quatro Aterros presentes no Município de Tremembé, sendo levados em consideração artigos publicados na imprensa, onde estes Aterros aparecem seriamente envolvidos com irregularidades, comprometendo parte da região.

Análises preliminares de amostras de água de pontos locados em áreas próximas aos Aterros apontaram significativos comprometimentos em função de suas atividades.

Devido à proximidade com um desses Aterros, em novembro de 2003, a CETESB apresentou parecer desfavorável à solicitação de licença para instalação de um frigorífico para abate e beneficiamento de rãs. É necessário ressaltar que, apesar disso, várias outras empresas continuam em plena atividade na região, podendo-se citar as agropecuárias e hortifrutigranjeiras muito próximas aos Aterros.

É preciso que se mencione também que o controle ambiental na área também é de imensa urgência, uma vez que é grande a área ocupada pela zona rural associada os Aterros.

Verificou-se ainda que um dos grandes problemas enfrentados pelos aterros era a disposição final do chorume. Para este trabalho selecionaram-se então, outros dois aterros, com características distintas dos primeiros, para propor uma solução para o chorume gerado nos aterros. 
Mediante a dinâmica dos aterros é imprescindível o estudo dos mecanismos de mobilidade e fixação dos íons metálicos nos diferentes compartimentos, bem como propostas de remediação e/ou mitigação para estes empreendimentos perigosos como, por exemplo, a destinação de chorume, um dos principais produtos das atividades dos aterros. 


\section{2- SÍNTESE BIBLIOGRÁFICA}

\section{1 - RESÍDUOS}

Os progressos tecnológicos alcançados pela humanidade aumentaram a qualidade e duração de vida, contudo, esse feito não ocorreu de forma sustentável o que acabou gerando grande desequilibro no meio ambiente, em especial após a Revolução Industrial, graças ao desenvolvimento das tecnologias e/ou pela explosão populacional.

$\mathrm{Na}$ vida contemporânea o consumo espelhado na globalização de estilo de vida, caracterizado pela fixação de certos padrões sociais, tem sido um dos responsáveis pelo aumento exacerbado no padrão de produção e geração de resíduos (TRIGUEIRO, 2003).

Dentre as várias classificações a respeito da origem dos resíduos, pode-se citar àquelas sugeridas por D'Almeida \& Vilhena (2000), destacando para este trabalho as seguintes:

- Domiciliar - originário na vida diária das residências, constituído de restos de alimentos, produtos deteriorados, jornais e revistas, garrafas, embalagens em geral etc;

- Comercial - originário nos diversos estabelecimentos comerciais e de serviços, tais como supermercados, estabelecimentos bancários, lojas etc. Esse tipo de resíduo possui grande quantidade de plásticos, papéis, embalagens diversas entre outros;

- Público - originário dos serviços de limpeza urbana, incluindo resíduos de varrição, limpeza de praias, limpeza de galerias, córregos e terrenos, restos de podas de árvores etc; 
- Industrial - originário de atividades dos diversos ramos da indústria, tais como metalúrgica, química, petroquímica, farmacêutica, alimentícia etc. Esse tipo de resíduo é bastante variado, podendo ser representado por cinzas, lodos, óleos, resíduos alcalinos ou ácidos, fibras, metais, escórias etc;

- Agrícola - originário de atividades agrícolas e da pecuária. Incluem embalagens de fertilizantes e de defensivos agrícolas, rações, resto de colheita etc.

O grande problema da geração de resíduos diz respeito à sua disposição. Somente através de inúmeros desastres ambientais resultantes de práticas inadequadas de disposição de resíduos, em especial os perigosos, é que se tem aumentado o conhecimento e preocupação sobre a questão.

Para analisar a extensão da agressão ao meio ambiente pode-se mencionar os impactos ocorridos em função de algum tipo de irregularidade no armazenamento, transporte e/ou disposição de resíduos, baseado nos trabalhos de AZEVEDO \& CHASIN, 2003 entre outros (QUADRO 2.1).

QUADRO 2.1 - Impactos ocorridos pelo descarte irregular de resíduos perigosos.

\begin{tabular}{|c|c|c|c|c|}
\hline $\begin{array}{c}\text { Ano e } \\
\text { Local de } \\
\text { ocorrência }\end{array}$ & Impacto ambiental & Principais efeitos & $\begin{array}{c}\text { Compartimento } \\
\text { ambiental } \\
\text { afetado }\end{array}$ & $\begin{array}{c}\text { Referência } \\
\text { bibliográfica }\end{array}$ \\
\hline $\begin{array}{c}2007 \\
\text { Brasil } \\
\text { (Santos) }\end{array}$ & $\begin{array}{l}\text { Escórias contendo } \\
\text { altos teores de metais } \\
\text { pesados, dispostas } \\
\text { inadequadamente. }\end{array}$ & $\begin{array}{l}\text { Contaminação do } \\
\text { mangue. }\end{array}$ & $\begin{array}{l}\text { Solo, água } \\
\text { subterrânea e } \\
\text { mangue. }\end{array}$ & $\begin{array}{c}\text { NASCIMENTO } \\
2007\end{array}$ \\
\hline $\begin{array}{c}2007 \\
\text { Brasil } \\
\text { (São Paulo) }\end{array}$ & $\begin{array}{c}\text { Resíduos de } \\
\text { galvanoplastia, } \\
\text { dispostos de forma } \\
\text { irregular. }\end{array}$ & $\begin{array}{l}\text { Solo, água } \\
\text { superficial e } \\
\text { subterrânea. }\end{array}$ & $\begin{array}{l}\text { Solo, águas } \\
\text { superficial e } \\
\text { subterrânea. }\end{array}$ & PUGAS, 2008 \\
\hline $\begin{array}{c}2003 \\
\text { Brasil } \\
\text { (Mogi das } \\
\text { Curzes) }\end{array}$ & $\begin{array}{l}\text { Altas concentrações } \\
\text { de metais pesados } \\
\text { em solo e água } \\
\text { superficial. }\end{array}$ & $\begin{array}{l}\text { Comprometimento } \\
\text { de solo de uso } \\
\text { agrícola }\end{array}$ & $\begin{array}{l}\text { Solo e água } \\
\text { superficial }\end{array}$ & $\begin{array}{l}\text { MARQUES, } \\
2003\end{array}$ \\
\hline
\end{tabular}

Continua... 


\begin{tabular}{|c|c|c|c|c|}
\hline $\begin{array}{c}2001 \\
\text { Texas, EUA }\end{array}$ & $\begin{array}{c}\text { Resíduos contendo } \\
\text { altas concentrações } \\
\text { de Al, Cu, Ba e outros } \\
\text { metais pesados } \\
\text { derramados durante o } \\
\text { transporte. }\end{array}$ & $\begin{array}{c}\text { Contaminação do } \\
\text { lago que fornece } \\
\text { água potável para } \\
\text { Atlanta e Texaskana } \\
\text { no Texas. }\end{array}$ & Água superficial. & NRC, 2001 \\
\hline $\begin{array}{l}1998 \\
\text { Suiça }\end{array}$ & $\begin{array}{l}\text { Rompimento de } \\
\text { parede de lago de } \\
\text { tratamento de } \\
\text { resíduos contendo } \\
\text { Pb, Cd, Cu e outros } \\
\text { metais pesados. }\end{array}$ & $\begin{array}{c}\text { Inundação de áreas } \\
\text { agrícolas com morte } \\
\text { de } 30 \text { t de peixes, } \\
40 \mathrm{t} \text { de anfíbios, } 20 \mathrm{t} \\
\text { de pássaros e } 8 \mathrm{t} \text { de } \\
\text { mamíferos. }\end{array}$ & $\begin{array}{c}\text { Água superficial } \\
\text { e solo. }\end{array}$ & $\begin{array}{l}\text { Sierra, } 2000 \\
\text { (apud } \\
\text { Cardoso, } \\
\text { 2001) }\end{array}$ \\
\hline $\begin{array}{l}1996 \\
\text { Sgurigrad, } \\
\text { Bolívia }\end{array}$ & $\begin{array}{l}\text { Rompimento da } \\
\text { Represa de mina de } \\
\mathrm{Cu}, \mathrm{Pb}, \mathrm{Zn} \text { e Ag. }\end{array}$ & $\begin{array}{c}\text { Resíduos } \\
\text { percorreram } 6 \mathrm{Km} \text {, } \\
\text { destruindo metade } \\
\text { de uma vila e } \\
\text { fazendo } 107 \\
\text { vítimas. }\end{array}$ & $\begin{array}{c}\text { Água superficial } \\
\text { e solo. }\end{array}$ & $\begin{array}{c}\text { NIRS/WISE } \\
2001\end{array}$ \\
\hline
\end{tabular}

Contraditório ao crescimento sustentável os eventos anteriormente citados foram responsáveis por grande desequilíbrio ambiental.

Embora o Brasil ainda mantenha muitos de seus resíduos, principalmente os domésticos, descartados em lixões e os industriais armazenados muitas vezes de forma irregular, na própria empresa, há uma preocupação crescente por parte dos Governos Federal, Estadual e Municipal, bem como de empresas privadas e uma pequena parcela da sociedade, que tem-se estruturado nas Organizações Não Governamentais (ONGs), com o objetivo de regularizar essa situação de modo a minimizar os impactos ambientais provocado pelos resíduos.

Os lixões são uma forma inadequada de disposição final de resíduos, que se caracterizam pelo simples descarte sobre o solo, sem medidas de proteção ao meio ambiente ou à saúde pública (D'Almeida \& Vilhena, 2000).

Os QUADROS 2.2 e 2.3 mostram respectivamente a evolução da coleta de resíduos sólidos urbanos e disposição dos resíduos industriais dos 
últimos anos, segundo dados fornecidos pela Associação Brasileira de Empresas de Limpeza Pública e Resíduos Especiais (ABRELPE).

QUADRO 2.2 - Quantidade coletada de resíduos sólidos urbanos no Brasil

\begin{tabular}{|c|c|c|c|c|c|c|}
\hline \multirow{2}{*}{ Macroregião } & \multicolumn{6}{|c|}{ Quantidade Coletada (t d $\mathbf{~}^{-1}$} \\
\cline { 2 - 7 } & $\mathbf{2 0 0 0}$ & $\mathbf{2 0 0 1}$ & $\mathbf{2 0 0 2}$ & $\mathbf{2 0 0 3}$ & $\mathbf{2 0 0 4}$ & $\mathbf{2 0 0 5}$ \\
\hline Norte & 11036,85 & 11313,23 & 11521,00 & 11755,96 & 12208,95 & 12569 \\
\hline Nordeste & 38454,60 & 39042,41 & 39497,59 & 40139,45 & 41135,71 & 41681 \\
\hline Sudeste & 73927,63 & 75216,36 & 76254,74 & 77828,45 & 79949,96 & 81139 \\
\hline Sul & 18008,54 & 18298,96 & 18530,32 & 18831,35 & 19380,88 & 19643 \\
\hline Centro-Oeste & 8476,64 & 8671,15 & 9058,45 & 9220,71 & 9556,53 & 9743 \\
\hline Brasil & 149904,27 & 152542,11 & 154862,10 & 157775,92 & 162232,03 & 164774 \\
\hline
\end{tabular}

Fonte: ABRELPE (2004)

QUADRO 2.3- Quantidade coletada de resíduos industriais no ano de 2004.

\begin{tabular}{|l|c|c|}
\hline $\begin{array}{c}\text { Tratamento elou } \\
\text { Disposição Final }\end{array}$ & $\mathbf{t}$ & $\%$ \\
\hline Aterros classe IIA e IIB & 1414000 & 83 \\
\hline Aterros classe I & 110000 & 6 \\
\hline Co-processamento & 145000 & 9 \\
\hline Incineração & 11000 & 1 \\
\hline Outros Tratamentos & 20000 & 100 \\
\hline Total & $\mathbf{1 7 0 0 0 0 0}$ & \\
\hline
\end{tabular}

Fonte: ABRELPE (2004)

Atualmente no Brasil, é gerado cerca de 163000 toneladas de lixo urbano (ABRELPE, 2004) sendo apenas 40\% destinados a aterros e do total dos resíduos industriais, apenas 30\% possuem destinação adequada. 
Uma pesquisa revelou que $73 \%$ dos municípios brasileiros com mais de 50 mil habitantes e em 70\% daqueles com menos de 50 mil habitantes ainda usufruem a utilização de lixões. A situação se agrava quando levam em consideração os dados fornecidos pelo IBGE (2002), onde 20\% dos domicílios brasileiros ainda não possuem coleta de resíduos.

Estudos mais recentes realizados pelo CEMPRE (Ciclosoft, 2008) demonstram que no Brasil o número de municípios atendidos com a coleta seletiva cresceu de 81 em 1994 para 405 em 2008; apesar do significativo crescimento esses valores correspondem apenas à $7 \%$ de todo o território brasileiro. Atualmente, os municípios que mais contribuem para a coleta seletiva são Santo André, Santos, São Bernardo e São José dos Campos.

Em relação aos resíduos industriais, a Associação de Empresas de Tratamento de Resíduos (ABETRE, 2004), aponta mais de 70\% de disposição inadequada.

Mesmo os resíduos que são destinados corretamente também precisam ser repensados, pois os aterros são locais que demandam grande área e constante manutenção para que não se transforme em um "lixão controlado". Ações voltadas para a coleta seletiva desenvolvida em alguns municípios brasileiros e a comercialização de resíduos industriais têm contribuído para a minimização desses materiais em aterros, entretanto ainda são ações pouco significativas diante do montante de resíduos gerados.

A população de modo geral ainda necessita romper a visão passiva de que a ciência tudo vai solucionar e deveria não apenas assumir uma visão crítica quando o assunto é impacto ambiental, mas sim assumir a responsabilidade também para si.

Dentre os elementos contidos nos resíduos perigosos estão os íons de metais pesados que em função de sua quantidade e especiação podem originar grandes danos ao meio ambiente e à população (Ezaki, 2004). 
A utilização dos metais pesados pelo homem influencia seu potencial de risco à saúde pelo menos de duas formas: pelo transporte ambiental, por intermédio da contribuição antropogênica ao ar, água, solo e sedimentos e por alteração da especiação do metal (GOYER, 1987).

Há necessidade de novas posturas frente aos problemas gerados pelos resíduos para que se possa permitir a capacidade de suporte do planeta para gerações futuras.

\section{2- ATERRO INDUSTRIAL}

Aterros industriais ainda são uma das formas legais de disposição de resíduos perigosos mais utilizado em nosso país, contudo esta deveria ser uma alternativa a ser considerada somente após tratamento, reciclagem ou reaproveitamento dos resíduos. Freqüentemente são destinados resíduos perigosos em aterros sanitários, pela falta de um programa eficiente de coleta, como por exemplo, o caso de pilhas e baterias de celulares (OLIVEIRA, 2001).

A escolha para a localização de áreas destinadas a implantação de aterros para resíduos perigosos é bastante complexa e pode, em muitos casos, gerar grandes conflitos de ordem política, sócio-econômica, legal e técnica (CETESB, 1993). O processo de decisão da escolha deve atender no mínimo a alguns critérios pré-estabelecidos pelas Normas Brasileiras de Resíduos (NBR 10 157, 1987), como apresentado no QUADRO 2.4. 
QUADRO 2.4 - Seleção de locais para implantação de aterros industriais

\begin{tabular}{|c|c|}
\hline $\begin{array}{l}\text { Características a serem consideradas } \\
\text { na escolha da área para construção de } \\
\text { aterros }\end{array}$ & $\begin{array}{c}\text { Características favoráveis à construção } \\
\text { de aterros }\end{array}$ \\
\hline $\begin{array}{l}\text { Grau de urbanização e compatibilidade da } \\
\text { vizinhança; }\end{array}$ & $\begin{array}{l}\text { Baixa densidade populacional na } \\
\text { vizinhança há } 500 \text { m das residências; }\end{array}$ \\
\hline Valor comercial do terreno; & $\begin{array}{l}\text { Baixo potencial de contaminação das } \\
\text { águas subterrâneas e superficiais; }\end{array}$ \\
\hline $\begin{array}{l}\text { Distância do (s) ponto (s) gerador (es) de } \\
\text { resíduos; }\end{array}$ & Baixo índice de precipitação pluviométrica; \\
\hline Condições de acesso; & Alto índice de evapotranspiração; \\
\hline Caracterização hidrogeológica & $\begin{array}{l}\text { Subsolo constituído por depósito extenso } \\
\text { e homogêneo de material argiloso; }\end{array}$ \\
\hline $\begin{array}{l}\text { Potencial de contaminação das águas } \\
\text { superficiais e subterrâneas; }\end{array}$ & $\begin{array}{l}\text { Declividade máxima de } 20 \% \text { no terreno, } \\
\text { para os aterros de resíduos sólidos } \\
\text { industriais; }\end{array}$ \\
\hline $\begin{array}{l}\text { Localização quanto a mananciais de } \\
\text { abastecimento de água; }\end{array}$ & $\begin{array}{l}\text { Distância de } 200 \mathrm{~m} \text { de corpos d'água } \\
\text { superficiais; }\end{array}$ \\
\hline
\end{tabular}

Fonte: ROCCA et al., 1993

As condições hidrogeológicas exigidas para a construção de aterros industriais aptos a receberem resíduos classe I, necessariamente devem conter uma espessura de camada de solo no mínimo de 1,5 m, sendo desejável de 3,0 m

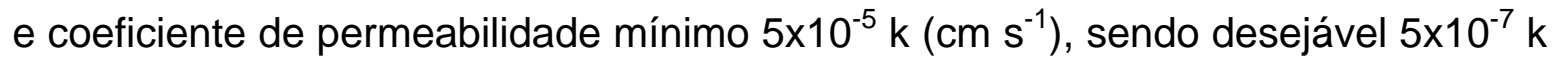
$\left(\mathrm{cm} \mathrm{s}^{-1}\right)$, segundo CETESB (1993).

Em especial, para a construção de aterros referentes à disposição de resíduos industriais classe I, devem ser seguidas as seguintes condições (CETESB op. cit., 1993):

- Vida útil mínima de 10 anos;

- Sistema de drenagem de águas pluviais capazes de suportar chuva de pico com 25 anos de período de ocorrência; 
- Implantação de duplo sistema de impermeabilização com dreno - na porção inferior do aterro;

- Implantação de sistema de coleta e tratamento de líquidos percolados (chorume).

Neste trabalho optou-se por um aterro cuja construção foi realizada em vala de grandes dimensões, dividida em módulos, com impermeabilização de base e drenagem de percolado (FIGURA 2.1).

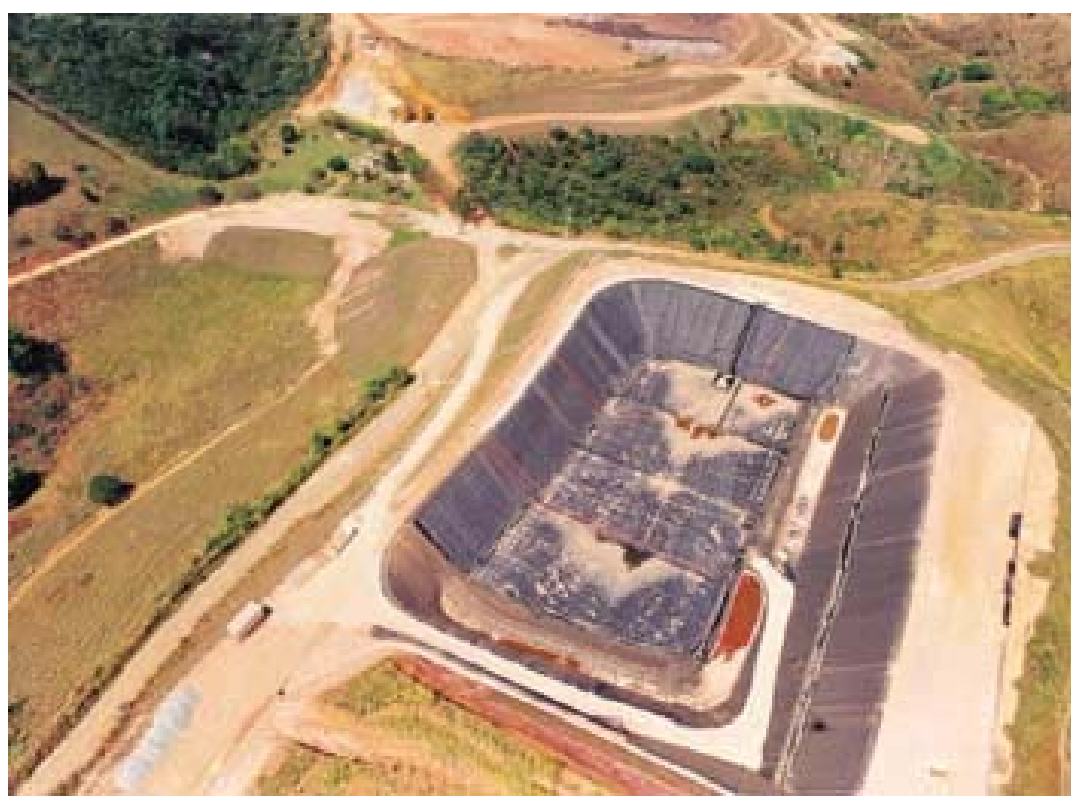

FIGURA 2.1 - Foto aérea do Aterro Industrial, parte do conjunto de aterros que compõem a área em estudo (www.ionyx.com.br)

Através deste breve levantamento bibliográfico, percebe-se a complexidade de disposição de resíduos industriais perigosos e que mesmo depois de seu encerramento é considerado ainda por cerca de 20 anos séria ameaça ao meio ambiente (DANIEL, 1993; LEÃO, 1998). É de se esperar que estes riscos sejam maiores quando 0 aterro é instalado em áreas hidrogeologicamente vulneráveis (MALTEZOU et al., 1989). 
$\mathrm{Na}$ tentativa de solucionar o problema do descarte de materiais sólidos perigosos, algumas empresas, municípios e outros setores estão desenvolvendo programas que minimizem e/ou eliminem a geração de resíduos.

O objetivo da minimização de resíduos inclui sua eliminação e/ou redução ainda na fonte. Caso sua geração não possa ser evitada, recomenda-se sua reciclagem, reutilização ou recuperação dos mesmos (STRAUS \& MENESES, 1994; RHYNER et al., 1995).

O setor industrial tem procurado comercializar seus resíduos convertendo-os em recursos financeiros e buscando tratamento e/ou disposição adequados apenas para os rejeitos.

A minimização de resíduos não é apenas uma questão de tecnologia que envolve planejamento, organização, atitudes inovadoras, práticas operacionais; consiste, fundamentalmente, em compromissos na busca de melhores condições de vida para as gerações futuras (SISINNO \& OLIVEIRA, 2000).

\section{3 - TRATAMENTO DE RESÍDUOS PERIGOSOS}

Os tratamentos de resíduos perigosos baseiam-se, fundamentalmente, em sua diminuição de volume (processo físico), neutralização química, com ou sem recuperação de produtos secundários (processo químico) e degradação de materiais pela ação de microorganismos (processo biológico).

\subsubsection{SECAGEM DE LODOS}

O processo consiste praticamente em remover a fase líquida, normalmente água, de resíduos sólidos e semi-sólidos. Ele precede a disposição do lodo, já desidratado, em aterros industriais. 
Os métodos usuais para secagem dos lodos consistem nas filtragens em filtros-prensa, à vácuo, na centrifugação e nos leitos de secagem (CETESB, 1993). Os leitos de secagens são um dos métodos mais antigos e bastante utilizados devido seu baixo custo.

\subsubsection{INCINERAÇÃO}

Diferentes tecnologias de incineração têm sido desenvolvidas para tratar os resíduos perigosos. Os projetos mais comuns de incineradores são: injeção líquida, fornos rotativos, câmara fixa e os de leito fluidizado (DEMPSEY \& OPPELT, 1999).

Os incineradores do tipo injeção líquida são aplicáveis quase que exclusivamente para resíduos líquidos bombeáveis. São normalmente cilindros revestidos internamente de refratários e equipados com um ou mais queimadores. Os resíduos líquidos são injetados através do (s) queimador (es), atomizados e queimados em suspensão (KIANG, 1977).

Segundo DEMPSEY \& OPPELT op. cit. (1999), os incineradores tipo forno rotativo, são os mais versáteis, devido ao fato de serem aplicáveis à destruição de resíduos sólidos, lamas e resíduos em contêineres, assim como os líquidos. São constituídos de um cilindro, revestido internamente com material refratário, montado com uma pequena inclinação. Devido sua grande versatilidade, normalmente encontra-se instalado em plantas de incineração comercial (DEMPSEY \& OPPELT op. cit., 1999).

Também conhecidos como incineradores de ar controlado, as câmeras fixas representam a terceira tecnologia atualmente em uso na incineração de resíduos perigosos. Apresentam capacidades menores que os incineradores de injeção líquida ou de fornos rotativos, devido às limitações físicas do alimentador e transporte de grandes quantidades de resíduos através da câmara de combustão. Entre os demais tipos de incineradores existentes é o que 
freqüentemente se encontra nas empresas, devido ao baixo capital exigido para instalação e reduzido potencial de requisitos de controle de emissão de particulados (DEMPSEY \& OPPELT op. cit., 1999).

Muito utilizado para queimar lodos gerados nas estações de tratamento de esgotos doméstico, os leitos fluidizados consistem em um vaso de combustão revestido de refratários parcialmente cheios com areia, alumina, carbonato de cálcio ou outro material inerte, o qual se mantém a uma temperatura que varia de 450 a $850^{\circ} \mathrm{C}$ (DEMPSEY \& OPPELT op. cit., 1999; CETESB, 1993).

De forma geral o processo de incineração parece bastante simples, no entanto é bem mais complexo do que se imagina, principalmente no que se refere aos cuidados com as emissões atmosféricas, como de particulados, metais pesados, dioxinas e furanos.

As dioxinas e furanos são sempre sub-produtos indesejáveis, que nunca se produzem intencionalmente, com exceção dos padrões para análises laboratoriais. Essas substâncias provêm essencialmente de processos químicos e térmicos (de combustão) especialmente quando estão envolvidas temperaturas entre $250^{\circ} \mathrm{C}$ e $350^{\circ} \mathrm{C}$, que favorecem sua formação (CHANG \& HUANG, 2000).

Os metais pesados são uma das preocupações na incineração de resíduos, face a sua presença em vários resíduos perigosos e também por seus possíveis efeitos adversos à saúde humana, quando da exposição às emissões. A principal preocupação ambiental centra-se no fato de onde e sob que forma física ou química os metais sairão do sistema de combustão, isto é, se nas cinzas residuais, nos materiais do sistema de retenção de poluição do ar ou nas emissões pelas chaminés. Desta forma, o maior interesse tem-se dirigido aos metais pesados associados às emissões atmosféricas que, segundo estudos, é a principal fonte poluidora desse sistema (DEMPSEY \& OPPELT op. cit., 1999). 


\subsubsection{ESTABILIZAÇÃO E SOLIDIFICAÇÃO}

Normalmente é uma técnica utilizada para grandes quantidades de resíduos perigosos e geralmente inorgânicos.

A estabilização consiste em um estágio de pré-tratamento através do qual os constituintes perigosos de um resíduo são transformados e mantidos nas suas formas menos solúveis ou menos tóxicas. Tais transformações se dão por meio de reações que fixam elementos ou compostos tóxicos em polímeros impermeáveis ou em cristais estáveis (CETESB, 1993).

\subsubsection{NEUTRALIZAÇÃO}

A fim de obter materiais próximos do meio neutro, o processo de neutralização consiste na adição de ácidos aos resíduos de natureza alcalina e de bases aos de características ácidas. Os produtos químicos ácidos mais comumente utilizados são ácidos sulfúrico, clorídrico e nítrico e os alcalinos soda cáustica, hidróxido de cálcio e carbonatos (CETESB op. cit., 1993).

\subsubsection{PRECIPITAÇÃO}

Este processo consiste basicamente na precipitação de compostos pouco solúveis (CETESB op. cit., 1993).

É bastante aplicado na remoção de metais pesados de efluentes industriais, contudo é um processo que se encontra comprometido pela participação de determinados compostos orgânicos que dificultam a formação da precipitação dos metais (WOODSIDE, 1993). 
Atualmente o processo mais utilizado baseia-se na adição de uma base como, por exemplo, hidróxido de cálcio, de modo que haja formação de produtos insolúveis na forma de hidróxidos e óxidos (JIMENEZ et al., 2004).

\subsubsection{LANDFARMING}

O Landfarming é um método de tratamento, onde o substrato, geralmente orgânico, de um resíduo é degradado biologicamente na camada superficial do solo (BATSTONE et al., 1989).

As principais vantagens para este tipo de tratamento são:

- Em curto prazo os resíduos mantêm-se na superfície, o que possibilita correções de eventuais problemas;

- $\quad$ Em longo prazo a manutenção é pequena já que os compostos orgânicos são biodegradáveis e o acúmulo de metais se restringe à superfície;

- Muitos resíduos são passíveis de serem tratados a baixos custos de implantação e operação, inclusive resíduos perigosos.

Como se observou é um processo que apresenta vantagens e é relativamente simples, contudo deve-se levar em consideração algumas propriedades do solo, como por exemplo, o pH, capacidade de troca catiônica, condutividade hidráulica, umidade, profundidade do lençol freático, textura do solo etc. (FULLER, 1986). 


\section{4 - ATERRO SANITÁRIO}

O aterro sanitário é um aprimoramento de uma das técnicas mais antigas que se conhece para o descarte de resíduos, que é o aterramento.

A despeito de ser, de longe, o método sanitário mais simples de destinação final de resíduos sólidos, o aterro exige cuidados especiais e técnicas específicas a serem seguidas, desde a seleção e preparo da área até sua operação e monitoramento.

No caso dos aterros sanitários a preocupação quanto a escolha do local e construção são tão importantes quanto aqueles realizados para os industriais.

O aterro sanitário consiste na disposição de resíduos domésticos no solo, sem causar danos ou riscos à saúde pública e à segurança, minimizando os impactos ambientais. Este método utiliza princípios de engenharia para confinar os resíduos sólidos à menor área possível e reduzí-los ao menor volume possível, cobrindo-os com uma camada de solo na conclusão de cada jornada de trabalho ou a intervalos menores se for o caso (NBR 8 419, 1992).

Alguns dos principais critérios e parâmetros para seleção de áreas destinadas à construção de aterros sanitários estão listados no QUADRO 2.5. 
QUADRO 2.5 - Condições desejáveis e não desejáveis para construção de aterros sanitários

\begin{tabular}{|c|c|c|c|}
\hline DADOS NECESSÁRIOS & $\begin{array}{c}\text { ÁREA } \\
\text { RECOMENDADA }\end{array}$ & $\begin{array}{c}\text { ÁREA } \\
\text { RECOMENDADA } \\
\text { COM RESTRIÇÕES }\end{array}$ & $\begin{array}{c}\text { ÁREA NÃO } \\
\text { RECOMENDADA }\end{array}$ \\
\hline Vida útil & Maior que 10 anos & $\begin{array}{l}\text { A critério do órgão } \\
\text { ambiental }\end{array}$ & Menor que 10 anos \\
\hline $\begin{array}{l}\text { Distância do centro } \\
\text { atendido }\end{array}$ & Menor que $10 \mathrm{~km}$ & $10-20 \mathrm{~km}$ & Maior que $20 \mathrm{~km}$ \\
\hline Zoneamento ambiental & $\begin{array}{r}\text { Áreas sem restric } \\
\qquad a m\end{array}$ & $\begin{array}{l}\text { ções no zoneamento } \\
\text { biental }\end{array}$ & $\begin{array}{c}\text { Unidades de } \\
\text { conservação } \\
\text { ambiental e } \\
\text { correlatas }\end{array}$ \\
\hline Zoneamento urbano & $\begin{array}{c}\text { Vetor de } \\
\text { crescimento } \\
\text { mínimo }\end{array}$ & $\begin{array}{l}\text { Vetor de crescimento } \\
\text { intermediário }\end{array}$ & $\begin{array}{c}\text { Vetor de crescimento } \\
\text { máximo }\end{array}$ \\
\hline Densidade populacional & Baixa & Média & Alta \\
\hline $\begin{array}{l}\text { Uso e ocupação das } \\
\text { terras }\end{array}$ & \multicolumn{2}{|c|}{ Áreas devolutas ou pouco utilizadas } & Ocupação intensa \\
\hline Valorização da terra & Baixa & Média & Alta \\
\hline $\begin{array}{c}\text { Aceitação da população } \\
\text { e de entidades } \\
\text { ambientais não } \\
\text { governamentais }\end{array}$ & Boa & Razoável & Inaceitável \\
\hline $\begin{array}{c}\text { Distância dos cursos } \\
\text { d'água }\end{array}$ & Maior que $200 \mathrm{~m}$ & \multicolumn{2}{|c|}{$\begin{array}{c}\text { Menor que } 200 \text { m, com aprovação do órgão } \\
\text { ambiental }\end{array}$} \\
\hline
\end{tabular}

Fonte: (NBR 13 896, 1 997)

Apesar do aterro sanitário ser uma solução viável para destinação de resíduos sólidos não perigosos, há algumas desvantagens em relação ao uso deste sistema como mostra o QUADRO 2.6. 
QUADRO 2.6 - Vantagens e desvantagens na utilização de aterros sanitários.

\begin{tabular}{|c|c|}
\hline VANTAGENS & DESVANTAGENS \\
\hline $\begin{array}{l}\text { Baixo custo comparado com outros } \\
\text { tratamentos. }\end{array}$ & $\begin{array}{l}\text { Perda de matérias-primas e da energia } \\
\text { contida nos resíduos. }\end{array}$ \\
\hline $\begin{array}{l}\text { Utilização de equipamentos de baixo custo } \\
\text { e de simples operação. }\end{array}$ & Transporte de resíduos à longa distância. \\
\hline $\begin{array}{l}\text { É possível a implementação em terrenos de } \\
\text { baixo valor. }\end{array}$ & $\begin{array}{l}\text { Desvalorização da região ao redor do } \\
\text { terreno. }\end{array}$ \\
\hline $\begin{array}{l}\text { Evitam a proliferação de insetos e animais } \\
\text { que transmitem doenças. }\end{array}$ & $\begin{array}{l}\text { Riscos de contaminação do solo e lençol } \\
\text { freático. }\end{array}$ \\
\hline $\begin{array}{l}\text { Não estão sujeitos a interrupções no } \\
\text { funcionamento por } \\
\text { operacional. }\end{array}$ & Produção de chorume e gases. \\
\hline & $\begin{array}{l}\text { Necessidade de manutenção e vigilância } \\
\text { após o fechamento do aterro. }\end{array}$ \\
\hline
\end{tabular}

\subsubsection{CONSTRUÇÃO}

A construção e operacionalização de aterros sanitários variam, principalmente, em função do tipo de terreno (CETESB, 1997). A área selecionada para este trabalho apresenta aterros construídos acima do nível do terreno e abaixo, como detalhado a seguir, segundo as especificações de CETESB op. cit., (1997).

Os aterros construídos na porção superior do terreno consistem na formação de camadas de resíduos compactados, que são sobrepostas acima do nível original resultando em configurações típicas de escadas, conforme mostra a FIGURA 2.2. 


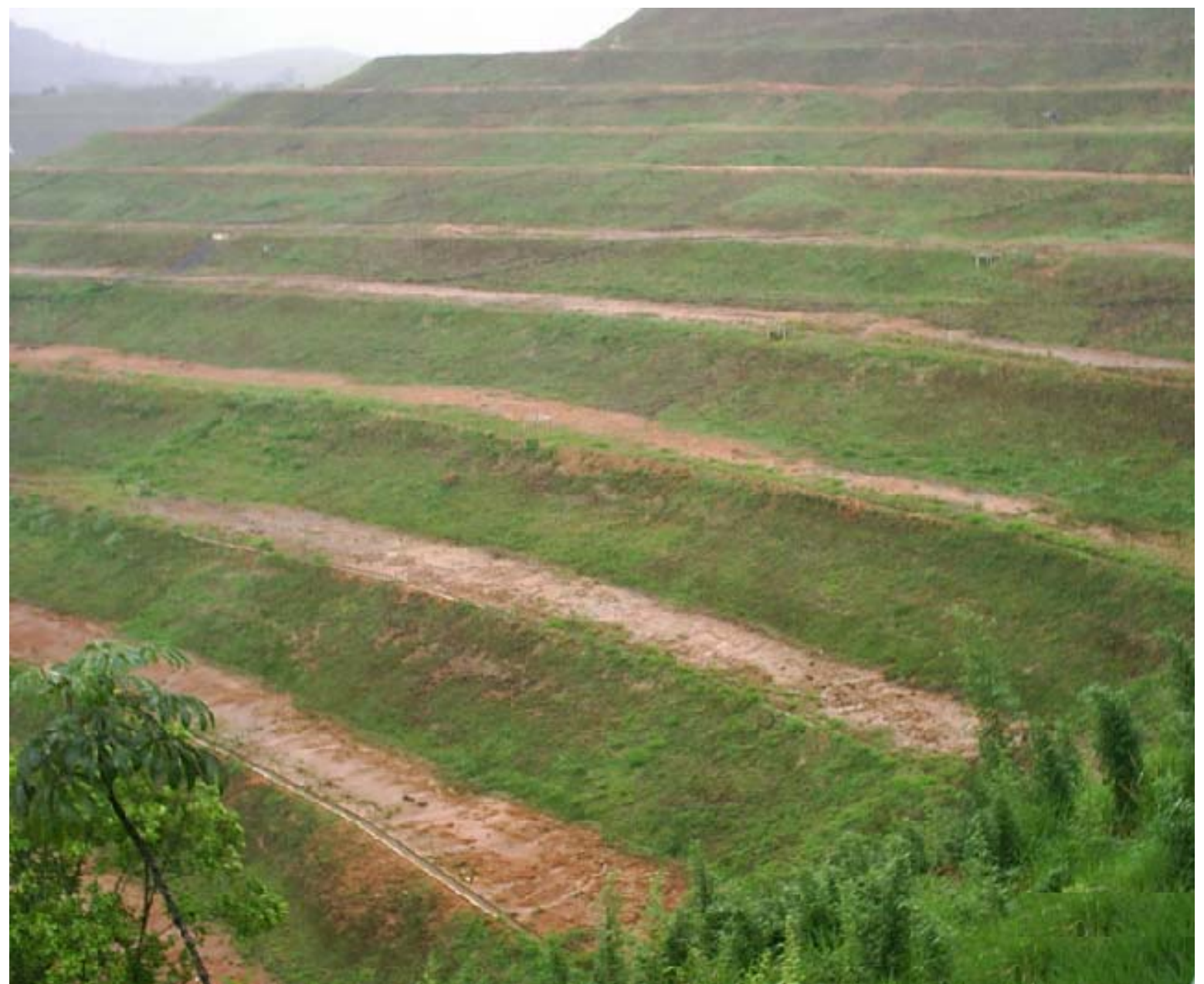

FIGURA 2.2 - Foto do Aterro Sanitário em estudo, construído acima do terreno, na forma de pirâmide.

Como o terreno onde está implantado o aterro apresenta topografia acidentada, os resíduos foram descartados junto à base de um desnível já existente, sendo, em seguida, compactados formando camadas de aproximadamente $0,4 \mathrm{~m}$ de espessura. A sobreposição dessas camadas é que gera a elevação do lixo compactado, de forma prismática, que periodicamente é coberta com terra, formando uma célula de lixo.

A cobertura de terra é aplicada de forma similar à utilizada na compactação dos resíduos, ou seja, é depositada na base do talude da célula e, em seguida, espalhada e compactada sobre os resíduos. As principais finalidades 
da cobertura com terra consistem em dificultar a entrada das águas de chuva, reduzir a proliferação de vetores e impedir o espalhamento de materiais mais leves.

Outro tipo de aterro sanitário é o construído abaixo do nível do terreno que no caso de um dos Aterros estudado, aproveitou-se escavações já existentes no local de uma antiga mineração de areia (FIGURA 2.3).

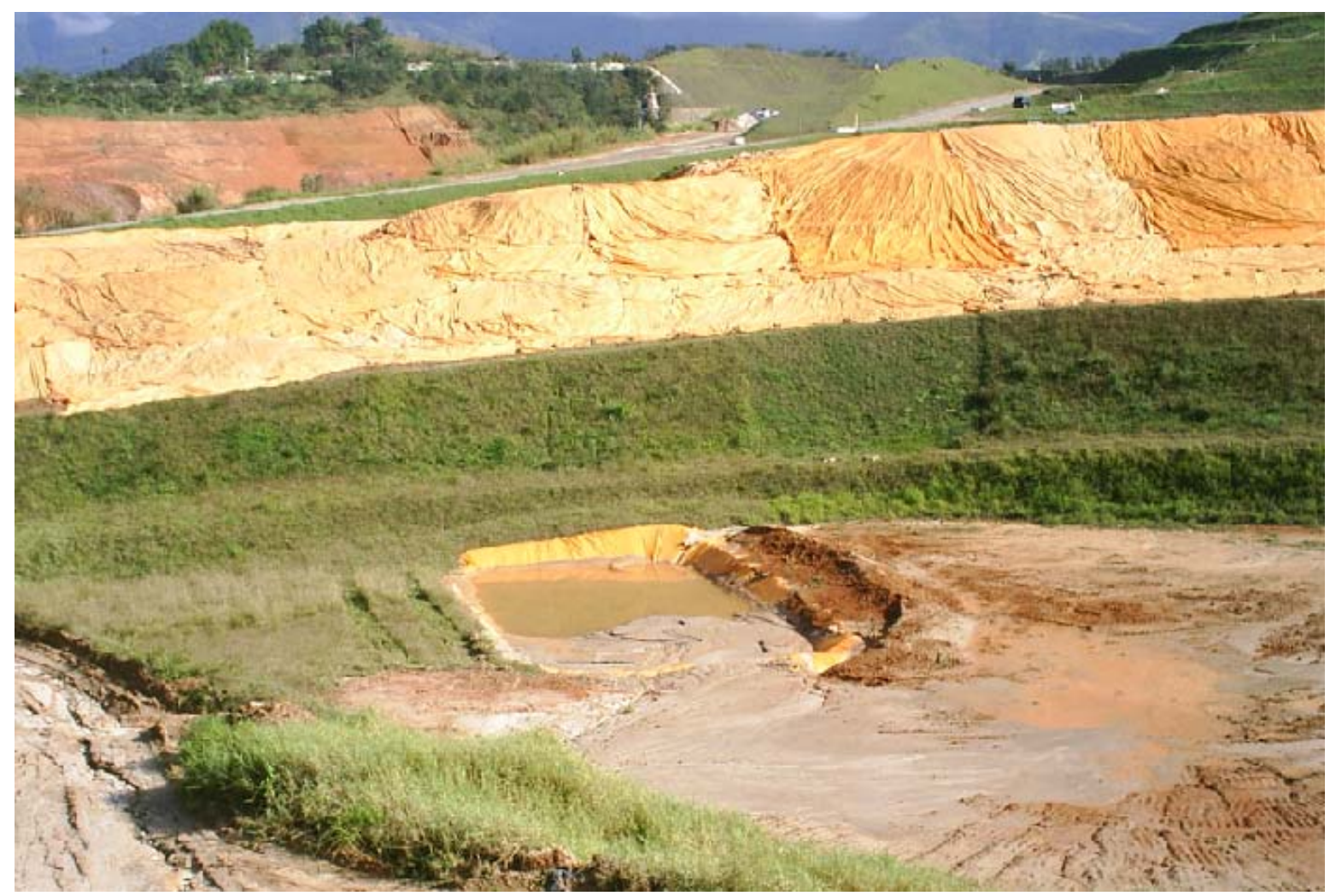

FIGURA 2.3 - Foto de Aterro Sanitário construído abaixo do terreno.

\section{5 - ÍONS METÁLICOS DE INTERESSE}

São vários os fatores que agem simultaneamente, interferindo na mobilidade e fixação de íons de metais pesados pelo solo como, por exemplo, precipitação direta, hidrólise e precipitação, precipitação precedida de 
complexação e precipitação precedida de redução (FERGUSON, 1991; NEDELKOSKA \& DORAN, 2000; SOARES et.al, 2005).

O compartimento que primeiro sofre com a contaminação por íons de metais pesados associados à aterros é o solo, que têm se caracterizado como obstáculo natural para os contaminantes em função, em especial, às reações de sorção, solubilização, precipitação e complexação que envolve o solo e o contaminante, além do controle de parâmetros como: pH, Eh, textura do solo, percentagem e tipos de minerais de argila, percentagem de matéria orgânica, Capacidade de Troca Catiônica (CTC), oxi-hidróxidos de Fe, Mn e Al e $\mathrm{CaCO}_{3}$ livre (SOLOMONS, 1995; KABATA-PENDIAS, 1995; BOULDING, 1995; MEURER et al., 2000; ANJOS, 2003).

O aumento nos valores de $\mathrm{pH}$ do solo, normalmente é acompanhado pela diminuição da mobilidade dos metais (ALLOWAY, 1995). Cátions como $\mathrm{Al}^{3+}$, $\mathrm{H}^{+}$adsorvidos nas partículas do solo influenciam os valores de $\mathrm{pH}$. $\mathrm{O}$ aumento desses íons adsorvido diminui os valores de pH (TAN, 1993).

Os óxi-hidróxidos de Fe, Al e Mn predominam, muitas vezes, em solos de regiões tropicais e semitropicais. Em condições específicas, esses elementos podem precipitar e adsorver cátions presentes nas soluções intersticiais do solo como, por exemplo, os íons de metais pesados (ALLOWAY op.cit, 1995; HAN, et. al, 2003).

Outro fator importante nas reações entre íons de metais pesados e solo é a Capacidade de Troca Catiônica (CTC) que está associada, sobretudo, ao tipo e teor do material argiloso e ao teor de matéria orgânica presente no solo (McBRIDE, 1994).

Alguns íons metálicos que inicialmente deveriam estar associados somente aos aterros destinados a resíduos classe I estão cada vez mais sendo encontrados associados também a aterros sanitários, em função principalmente do ineficiente programa de gestão de resíduos sólidos implantados em nossa sociedade. 
As principais propriedades e características dos metais de interesse neste estudo são descritas a seguir.

\subsubsection{ALUMÍNIO}

O alumínio atinge a atmosfera como o maior constituinte particulado, derivado de poeiras do solo em função de processos de erosão e particulados oriundos da combustão do carvão vegetal (GRANT et. al, 1990). Além dos processos naturais, as atividades antrópicas como mineração, indústrias e agricultura também apresentam importante contribuição para a eliminação deste elemento (FILIPEK et. al, 1987).

Em sistemas subterrâneos ou superficiais, é possível a ocorrência de alumínio dissolvido. A solubilidade do alumínio em equilíbrio com a fase sólida $\mathrm{Al}(\mathrm{OH})_{3}$ é altamente dependente dos valores de pH (ALFREY, 1984).

Teores de alumínio adsorvidos em partículas suspensas mostram íntima relação com o pH da água, uma vez que o pH é um potencial agente determinante de sua solubilidade (AZEVEDO, 2003).

No solo, a acidificação natural resulta no aumento da solubilidade do alumínio; em níveis moderadamente ácidos ( $\mathrm{pH}=5,5)$, aparece inicialmente como hidróxidos polinucleares e, posteriormente, como íons mononucleares simples. Os íons alumínio retiram o cálcio permanentemente dos sítios de troca (BACHE, 1986).

O sistema de troca cationica de solos ácidos tem sua origem na grande reserva de alumínio iônico. Soluções ligantes como os fluoretos e ânions orgânicos que formam complexos à base de alumínio, se combinam e são responsáveis pela manutenção dos altos níveis de alumínio que são esperados, especialmente quando o pH está entre 5 e 7 (BACHE op. cit, 1986). O diagrama da FIGURA 2.4 mostra o comportamento do alumínio, decorrente dos valores de $\mathrm{pH}$. 


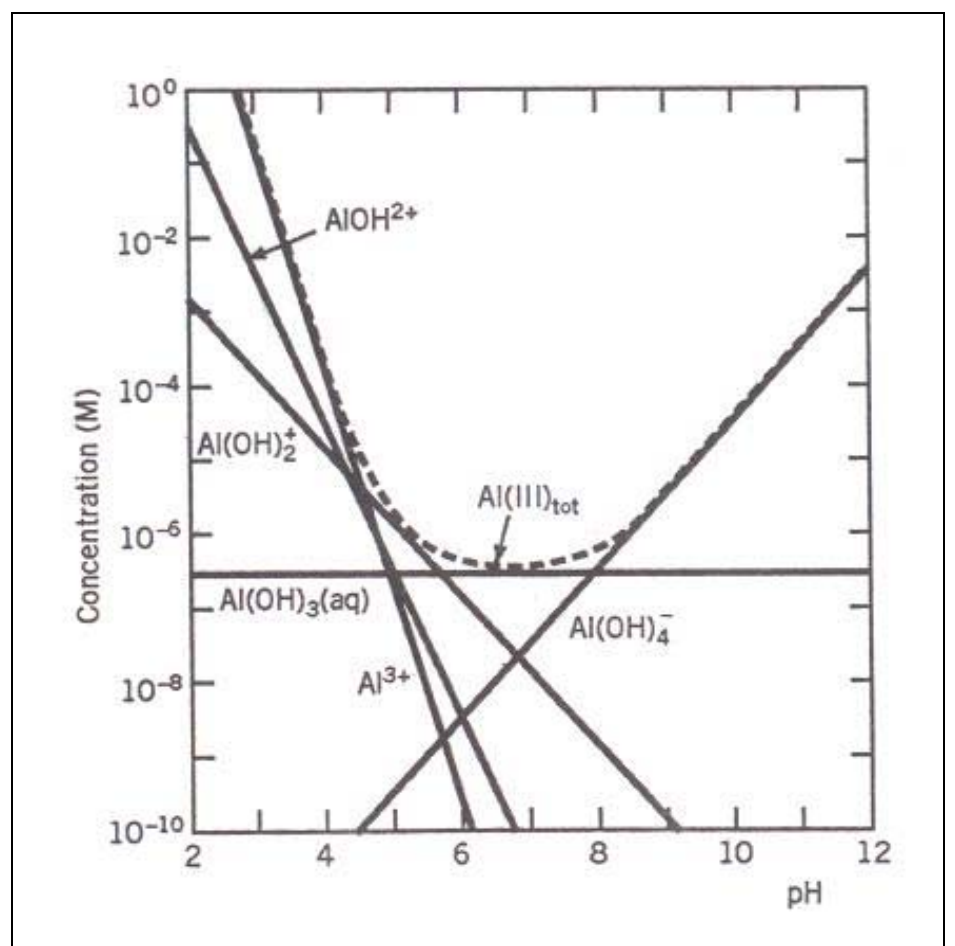

FIGURA 2.4 - Diagrama da concentração de alumínio em função dos valores de pH. Fonte: STUMM \& MORGAN, 1995.

No solo, a maior parte da forma solúvel de alumínio sob condições ácidas é formada pelos compostos orgânicos ligados ao alumínio; desta forma, o hidróxido de alumínio amorfo é mais solúvel que as formas cristalinas (ATSDR, 1992).

O valor de intervenção adotado pela CETESB (2005) para o alumínio em águas subterrâneas é de $200 \mu \mathrm{g} \mathrm{L} \mathrm{L}^{-1}$. Segundo a Resolução 396/08 do CONAMA, o valor de referência para consumo humano também é $200 \mu \mathrm{g} \mathrm{L}^{-1}$.

\subsubsection{FERRO}

O ferro, quarto elemento mais abundante na crosta terrestre e com depósitos de minérios distribuídos por todos os continentes, é liberado dessas fontes naturais para o ar, água, sedimento e solo (SIENKO, 1977). 
A maior parte do ferro na crosta terrestre está presente como $\mathrm{Fe}^{2+} \mathrm{e}$ pode ser rapidamente oxidado na superfície a $\mathrm{Fe}^{3+}$, forma insolúvel em água (COX, 1997).

Os compostos de ferro são liberados para a atmosfera principalmente na forma de material particulado. É removido pela sedimentação ou pelas águas das chuvas, sendo essa remoção relacionada com o tamanho das partículas e com as condições meteorológicas do local (CERCASOV et al., 1998).

Na água, o ferro pode ocorrer na forma iônica ou complexada, como íon di ou trivalente, em estado coloidal ou disperso. O ferro ocorre na forma iônica $\left(\mathrm{Fe}^{2+}\right)$ se a água estiver livre de oxigênio ou em pH abaixo de 3. Em condições de aerobiose, íons ferrosos são convertidos a íons férricos que, por sua vez formam hidróxidos de ferro insolúveis (FRESENIUS et al., 1988).

A quantidade de ferro num solo, sem interferência antropogênica, depende da proximidade deste com rochas naturais e do grau de intemperismo ao longo do tempo. Os metais podem estar na forma solúvel, fixada pelos minerais dos solos, precipitada com outros componentes, na biomassa ou complexada com matéria orgânica. A atividade de um dado metal na solução do solo é determinada pelo seu equilíbrio entre as partículas de argila, matéria orgânica, óxi-hidróxidos de ferro, alumínio, manganês e quelantes solúveis. O tipo de solo, portanto, tem um papel fundamental na distribuição de elementos metálicos. Solos com elevado teor de argila, por exemplo, tendem a reduzir a mobilidade e disponibilidade dos metais para os vegetais (WARMAN \& COOPER, 2000).

O valor de intervenção adotado pela CETESB (2005) para o ferro, bem como para consumo humano segundo a Resolução 396/08 do CONAMA, em águas subterrâneas, é de $300 \mu \mathrm{g} \mathrm{L}^{-1}$. 


\subsubsection{MANGANÊS}

$\mathrm{Na}$ água o manganês sofre oxidação dependendo do $\mathrm{pH}$, do potencial oxidorredução e da atividade microbiana. Fatores de bioconcentração indicam que o manganês se acumula mais em organismos de níveis tróficos inferiores do que em relação aos superiores (ATSDR, 2000).

O estado de oxidação do manganês em solos e sedimentos pode ser alterado pela atividade microbiana. Os microorganismos também podem aumentar a mobilidade desse metal (ATSDR op cit., 2000). Há um equilíbrio dinâmico entre as formas do manganês, sendo a forma bivalente, através da oxidação biológica, transformada na forma trivalente que, posteriormente, é reduzida a $\mathrm{Mn}^{2+}$ em solos muito ácidos (WHO, 1981; WHO 1999).

O manganês é freqüentemente transportado nos rios, adsorvidos aos sedimentos suspensos. A tendência dos compostos solúveis de serem adsorvidos nos solos e sedimentos pode ser altamente variável, dependendo principalmente, da capacidade de troca iônica dos cátions e da composição orgânica do solo (WHO op cit., 1999).

O valor de intervenção adotado pela CETESB (2005) para o manganês em águas subterrâneas é de $300 \mu \mathrm{g} \mathrm{L}^{-1}$. Para o consumo humano a Resolução 396/08 do CONAMA é $100 \mu \mathrm{g} \mathrm{L}{ }^{-1}$.

\subsubsection{CHUMBO}

O chumbo é um poluente ambiental extremamente tóxico e penetrante, sendo conhecido seus efeitos maléficos desde a Antigüidade.

As emissões de chumbo ocorrem em processos de fundição como em alguns ramos da indústria química de plásticos (BRENA, 2002). 
Disperso na atmosfera, o chumbo acaba sendo depositado nas águas (lagos, rios e oceanos) e/ou no solo, trazidos pela chuva. Quando acumulado no solo também pode acabar indo para as águas subterrâneas, através da lixiviação (ATSDR, 1999).

O chumbo, quando presente na água, em função principalmente dos valores de $\mathrm{pH}$, dos sais dissolvidos e da presença de agentes complexantes, pode residir na água ou encaminhados para os sedimentos (ATSDR op. cit., 1999). Águas com baixas concentrações de cálcio dissolvido, por exemplo, aumentam a solubilidade do chumbo de $30 \mu \mathrm{g} \mathrm{L}^{-1}$ (em águas duras) para $500 \mu \mathrm{g} \mathrm{L}^{-1}$ (WHO, 1995).

Fração representativa de chumbo tem sido encontrada na forma insolúvel carregado pelas águas dos rios. Essa forma consiste em partículas coloidais ou de carbonato, óxidos ou hidróxidos de chumbo incorporados em componentes de matérias lixiviadas do solo (ATSDR op. cit., 1999).

A movimentação do chumbo do solo para as águas subterrâneas por lixiviação é muito lenta na maioria das condições naturais, exceto em situações de elevada acidez (MUNDELL, 1989).

O chumbo encontrado em águas superficiais pode estar complexado tanto com compostos orgânicos naturais (ácidos húmicos) como compostos de origem antropogênica (ácido etilenodiaminotetracético). A presença desses agentes quelantes na água pode aumentar de 10 a 60 vezes os níveis de compostos de chumbo em solução (WHO op. cit., 1995).

No solo, o acúmulo de chumbo ocorre principalmente em função da taxa de deposição da atmosfera. Na maior parte o chumbo fica retido nas camadas superficiais do solo, no entanto pode ser transportado para as águas superficiais e subterrâneas. Os fatores que podem auxiliar o transporte e a disponibilidade do chumbo no solo são os valores de pH, composição mineral do solo, matéria orgânica, presença de colóides inorgânicos, presença de óxidos de ferro e a capacidade de troca iônica (WHO op. cit., 1995). 
A liberação do chumbo de complexos orgânicos para a forma solúvel está relacionada diretamente com os valores de $\mathrm{pH}$. Em solos com $\mathrm{pH} \geq 5$ e contendo pelo menos $5 \%$ de matéria orgânica, o chumbo atmosférico é retido na camada superior do solo. Em solos que apresentam alto teores de matéria orgânica e pH entre 6 e 8, o chumbo pode formar complexos orgânicos insolúveis. Se o solo apresentar pouca quantidade de matéria orgânica e o mesmo pH, podem ser formados compostos óxidos-hidróxidos ou ainda ocorrer sua precipitação na forma de carbonatos ou fosfatos. Em pH entre 4 e 6, os complexos orgânicos do chumbo formados tornam-se solúveis e sofrem lixiviação ou podem ser absorvidos pelas plantas ( WHO, 1995). Os valores de $\mathrm{pH}$ são bastante significativos para entender o comportamento do chumbo, como por exemplo, o diagrama de pH em função da concentração mostrado na FIGURA 2.5.

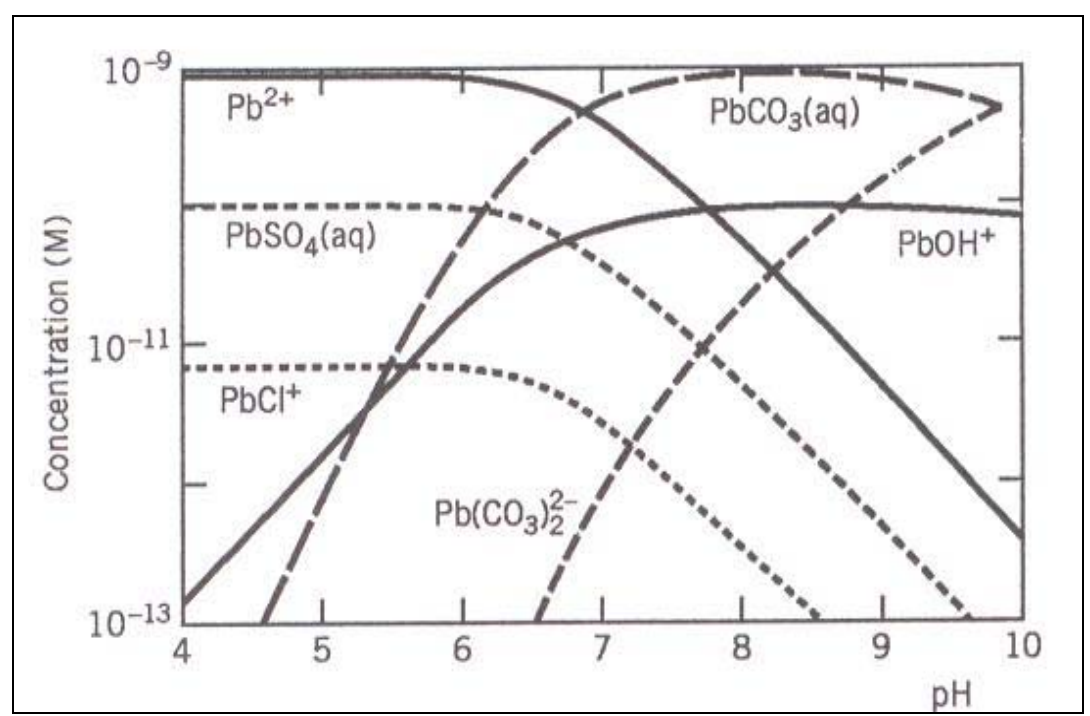

FIGURA 2.5 - Diagrama da concentração de chumbo em função dos valores de pH. Fonte: STUMM \& MORGAN, 1995

De modo geral, as concentrações naturais de chumbo no solo são baixas chegando até 30 ppm. Valores de referência para solos e águas subterrâneas foram sugeridos pela CETESB (2005), sendo de $17 \mathrm{mg} \mathrm{kg}^{-1}$ para solos e $10 \mu \mathrm{g} \mathrm{L}^{-1}$ para águas subterrâneas. O CONAMA através da Resolução 396 de 2008 manteve esses valores para o chumbo. 
Existem ainda os valores de intervenção que se baseiam na avaliação de risco, tendo um caráter corretivo. Indicam a existência de contaminação do solo ou água subterrânea. Os valores de intervenção para solos agrícolas, residenciais e industriais foram estabelecidos em 180, 300 e 900 mg $\mathrm{kg}^{1}$, respectivamente.

Para os sedimentos a CETESB utiliza os valores de 35 e $91,3 \mathrm{mg}$ $\mathrm{kg}^{-1}$ - Interim Sediment Quality Guideline (ISQG) e Probable Effect Level (PEL), respectivamente, sugeridos por SMITH, 1996.

\section{6 - CHORUME}

Os chorumes são líquidos escuros e turvos, de odor desagradável, gerados na decomposição do lixo e apresentam em sua composição altos teores de compostos orgânicos nas suas formas dissolvida e coloidal.

A formação do chorume está condicionada a fatores que resultam em uma composição química variável dependendo, principalmente, do tipo de resíduos presente no aterro. Fatores climáticos (chuva, escoamento superficial, infiltração, evapotranspiração e temperatura) também são fatores que influenciam diretamente na formação de chorume.

Através da compactação do lixo e degradação da matéria orgânica o ambiente do aterro torna-se anaeróbio aumentando o índice de carga orgânica do chorume, tornando sua composição cada vez mais complexa (KJELDSEN et al., 2002).

A variabilidade da composição dos resíduos aterrados pode produzir chorumes com elevados teores de metais pesados, além de substâncias xenobióticas, matéria orgânica dissolvida, macronutrientes inorgânicos e microorganismos perigosos à saúde (CHRISTENSEN et al., 2001). No QUADRO 2.7 estão alguns desses íons encontrados no chorume e suas possíveis fontes. 
QUADRO 4.7 - Chorume: principais íons e origens

\begin{tabular}{|c|c|}
\hline Íons & Fontes \\
\hline $\mathrm{Na}^{+}, \mathrm{K}^{+}, \mathrm{Ca}^{2+}, \mathrm{Mg}^{2+}$ & material orgânico, entulhos de construção \\
\hline $\mathrm{PO}_{4}{ }^{3-}, \mathrm{NO}_{3}{ }^{-}, \mathrm{CO}_{3}{ }^{2-}$ & material orgânico \\
\hline $\mathrm{Cu}^{2+}, \mathrm{Fe}^{2+}, \mathrm{Sn}^{2+}$ & material eletrônico, latas, tampas de garrafas \\
\hline $\mathrm{Hg}^{2+}, \mathrm{Mn}^{2+}$ & pilhas comuns e alcalinas, lâmpadas fluorescentes \\
\hline $\mathrm{Ni}^{2+}, \mathrm{Cd}^{2+}, \mathrm{Pb}^{2+}$ & baterias recarregáveis (celular, telefone sem fio, automóveis) \\
\hline $\mathrm{Al}^{3+}$ & latas, utensílios domésticos, cosméticos, embalagens \\
\hline $\mathrm{Cl}^{-}, \mathrm{Br}^{-}, \mathrm{Ag}^{+}$ & tubos de PVC, negativos de filmes de raios-X \\
\hline $\mathrm{Sb}^{3+}, \mathrm{Cr}^{3+}, \mathrm{Cr}^{6+}, \mathrm{Pb}^{2+}$ & embalagens de tintas, vernizes, solventes orgânicos \\
\hline
\end{tabular}

Fonte: CHRISTENSEN et al., 2001

Em um aterro, a formação dos compostos e suas características, acham-se relacionadas ao processo de decomposição da matéria orgânica que ocorrem basicamente em condições aeróbias e anaeróbias.

A fase aeróbia ocorre nas camadas superficiais do aterro, onde ainda há oxigênio disponível para desenvolvimento de bactérias aeróbias. A fase da decomposição se dá de forma bastante rápida (CHRISTENSEN et al., 1992) com aumento considerável da temperatura e formação de gás carbônico, água, nitrato, fosfato e sulfato. Nesta fase o chorume apresenta elevadas concentrações de sais dissolvidos, inclusive íons de metais pesados (D'Almeida \& Vilhena, 2000).

Com o término do oxigênio livre inicia-se a fase anaeróbia que, ao contrário a primeira fase, apresenta tempo de duração maior. Bactérias facultativas e anaeróbias produzem enzimas responsáveis pela conversão de compostos orgânicos complexos e insolúveis em materiais mais simples e solúveis (CHRISTENSEN et al., 2001).

Ao longo dos anos formam-se substâncias recalcitrantes que dificultam ou impossibilitam sua degradação (OLIVEIRA e MOTA, 1998; BILA, 2000). Os principais fatores que contribuem para a resistência à 
biodegradabilidade podem ser formação de estruturas químicas complexas desprovidas de grupos funcionais reativos, moléculas que podem exercer ação tóxica sobre a microflora ou ainda inativar enzimas-chaves do metabolismo celular ou podem complexar ou interagir com elementos ou compostos químicos tornando-se pouco acessível às enzimas extracelulares e a posterior metabolização (SILVA, 2002).

Como o chorume é um efluente quimicamente muito complexo, com características particulares para cada aterro e com enorme variedade em sua composição, é fundamental que se faça uma avaliação rigorosa do tipo de tratamento que se enquadra às suas características.

O chorume produzido na área de estudo é, em parte, tratado pela própria empresa, como mostra o esquema da FIGURA 2.6. 


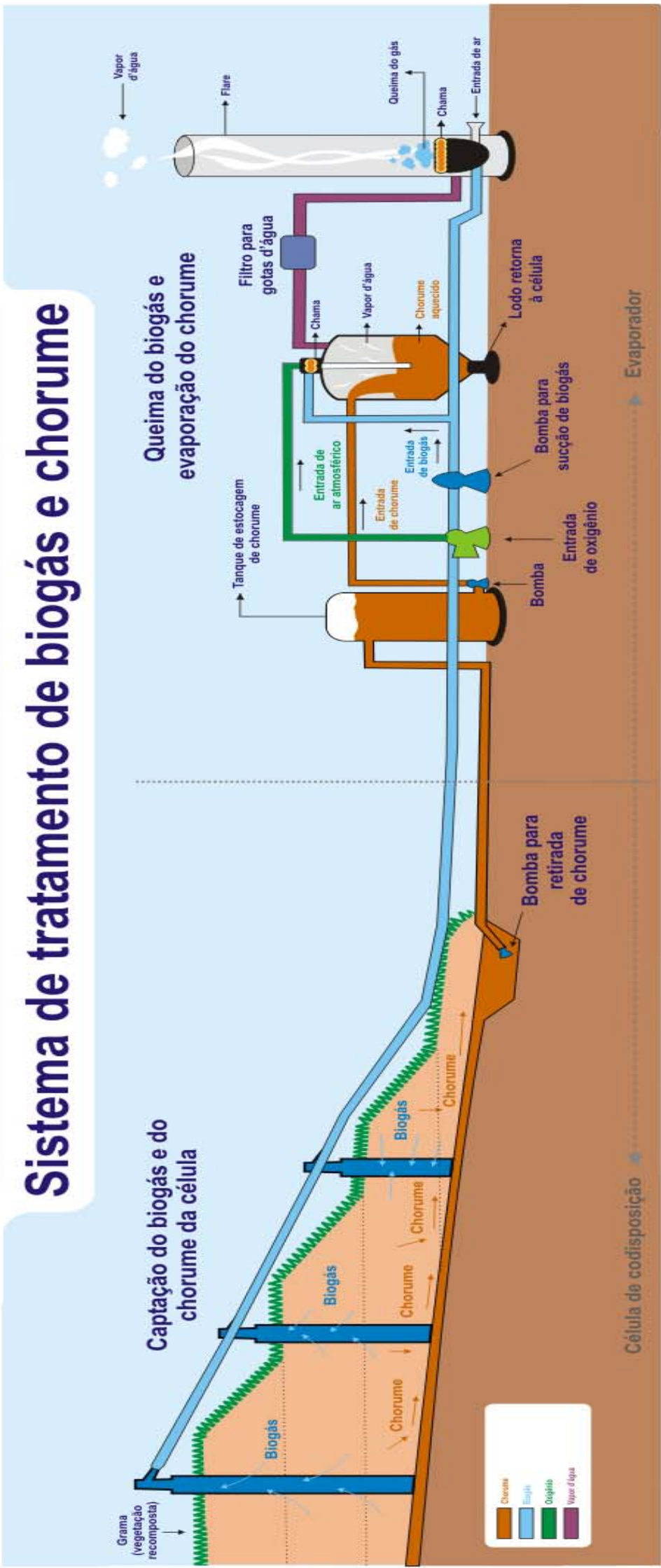

FIGURA 2.6 - Placa de evaporação 
Os principais processos de tratamento do chorume baseiam-se na remoção de substâncias orgânicas biodegradáveis (processo biológico), controle de $\mathrm{pH}$, remoção de compostos inorgânicos e de materiais em suspensão, degradação de compostos orgânicos (processo químico) e separação dos materiais em suspensão ou sedimentados (processo físico).

\section{7 - TÉCNICAS EMPREgADAS PARA TRATAMENTO DE CHORUME}

Cada aterro gera chorume com características específicas que, variam fundamentalmente com a idade do aterro que, no entanto, pode, independente da sua vida útil, apresentar interferências relacionadas aos índices pluviométricos detectadas ao longo de um período de seis meses (CINTRA et al., 2002).

Segundo IWIAI (2005) a solução dos problemas gerados pelo chorume não deve se resumir na escolha do melhor processo de tratamento, mas sim, constituir num programa para eliminação dos riscos potenciais de contaminação de aqüíferos provocados por este efluente, denominado manejo do chorume. Diversas técnicas podem ser empregadas entre as quais são detalhadas a seguir.

\subsubsection{TRATAMENTO PRIMÁRIO}

O tratamento primário remove partículas coloidais, material sólido em suspensão e ajusta o pH para posterior tratamento do efluente.

A coagulação é um processo muito utilizado por promover a clarificação de efluentes industriais contendo partículas coloidais e sólidos em suspensão. Consiste na adição de agentes químicos para neutralizar as cargas elétricas das partículas. O coagulante mais utilizado é o sulfato de alumínio ou 
sulfato de ferro (III), por apresentarem altas valências, favorecendo a coagulação (DEZOTTI \& RUSSO, 1997).

Para auxiliar no tratamento de coagulação/floculação estão sendo empregados compostos sintéticos, denominados polieletrólitos, que são substâncias poliméricas com alto peso molecular, solúveis em água, contendo cargas elétricas em sua estrutura. O polieletrólito é uma substância que não é afetada pelo $\mathrm{pH}$ do meio e pode servir como coagulante, uma vez que reduz a carga efetiva das partículas coloidais (ECKENFELDER, J. W. W., 1989).

Com o objetivo de remover material orgânico recalcitrante (dificuldade ou impossibilidade de degradação de certas substâncias químicas na natureza), por processo de coagulação/floculação, foram testadas melhores condições de pH, concentração dos agentes empregados e melhor conjunto de coagulantes e polieletrólito. O sulfato de alumínio foi o que apresentou o melhor desempenho, com a faixa de $\mathrm{pH}$ ótimo entre 4,5 - 5,0 e dosagem ótima entre 700 e 950 (mg/L). O estudo apresentou bons resultados em termos de remoção de DQO (Demanda Química de Oxigênio) e boa clarificação do efluente, sendo adequado à formação e tamanho dos flocos (BILA, 2000).

\subsubsection{TRATAMENTO OXIDATIVO}

Processos Oxidativos Avançado - (POA's), altamente eficiente para destruir substâncias orgânicas de difícil degradação e geram como produtos finais da reação $\mathrm{CO}_{2}$ e $\mathrm{H}_{2} \mathrm{O}$ (DEZZOTTI \& RUSSO op. cit., 1997).

Os POA's produzem radicais hidroxil $\left(\mathrm{OH}^{\circ}\right)$ altamente oxidantes, capazes de oxidar completamente as moléculas orgânicas presentes em águas poluídas. A oxidação com ozônio, com peróxido de hidrogênio combinados ou não com radiação ultra violeta (UV), bem como a fotocatálise se constituem nos POA's com alto potencial de uso.

Para as espécies inorgânicas que se apresentam na forma reduzida, o ozônio é um excelente oxidante por gerar compostos com baixa solubilidade que, na forma de precipitados, podem ser removidos facilmente do meio aquoso 
por filtração (ANDRADE, 2001). As principais vantagens desse processo, segundo (DEZOTTI, 1997) e (STENSEN, 2000) são que não requerem a transferência de fase do poluente (como a adsorção em carvão ativo), apresentam alto potencial de oxidação, não formam sub-produtos sólidos (lodo), podem levar à mineralização completa dos poluentes ou a formas biodegradáveis ou a compostos não tóxicos, promovem a remoção de cor e removem ferro e manganês.

\subsubsection{TRATAMENTO BIOLÓGICO}

Em chorume de aterros antigos, o tratamento biológico tem se mostrado pouco eficiente devido a quantidade de material não degradável ser normalmente elevada. Lodos ativados, lagoas aeradas e filtros biológicos são alguns dos processos biológicos para tratamento de chorume.

Nos testes de tratabilidade biológica com amostra de chorume prétratado pelo processo de coagulação/floculação, observou-se que o lodo ativado perdeu sua atividade com o aumento da concentração de chorume na alimentação do reator. Estas conclusões foram subsidiadas pela constatação da escassez de flocos que quase não apresentaram filamentos estruturais e ausência de protozoários, indicativos de lodo com características inadequadas (BILA, 2000).

A utilização de lagoas aeradas é bastante utilizada como etapa que precede a disposição final do chorume em estações de tratamento de esgotos, onde tem-se bons resultados de biodegradação, obtidos para chorumes provenientes de aterro jovens. Foi verificado que nos aterros de grande porte, os sistemas adotados para o tratamento do chorume envolvem, além das lagoas e tanques de aeração, os wetlands e tratamento com ozônio para reduzir materiais orgânicos complexos em compostas mais simples (ROBINSON, 1993).

O processo de nitrificação/desnitrificação foi considerado como método econômico e mais efetivo para remoção de nitrogênio, no tratamento de chorume produzido em aterro sanitário contendo altas concentrações de amônia. Nesse estudo a concentração de amônia teve uma redução de 50\% (WOO, et al., 2000). 
Os filtros biológicos são eficientes na remoção de compostos orgânicos biodegradáveis e também promovem a nitrificação (McBEAN et al., 1995).

Apesar das diferenças entre as características dos chorumes gerados nos aterros, o tratamento biológico é muito citado na literatura como opção de tratamento. No entanto, observa-se que esse tipo de tratamento pode ser ineficiente em se tratando de chorume provenientes de aterros de meia-idade, pelo fato do despejo apresentar-se mais resistente à biodegradação (FERREIRA et al., 2002).

Por não apresentarem bom desempenho na presença de metais tóxicos (ex. Cu, Zn, e Ni podem inibir a nitrificação). Algumas desvantagens em relação aos processos biológicos podem ser demanda de adição de fósforo para assegurar o tratamento aeróbio, visto que é freqüente a deficiência desse elemento no chorume, levam à formação de espuma na aeração artificial e pode ocorrer precipitação de $\mathrm{CaCO}_{3}$ com prejuízo ao equipamento de aeração.

\subsubsection{SEPARAÇÃO COM MEMBRANAS}

O processo de separação por membranas, em função de suas características, pode ser classificado como: microfiltração, ultrafiltração, nanofiltração e osmose inversa.

A eficiência de uma membrana é determinada por dois parâmetros: seletividade e fluxo de permeação. A seletividade é expressa, pela rejeição, onde o soluto é parcial ou completamente retido, enquanto o solvente (geralmente água) passa pela membrana.

O processo com membranas têm também como objetivo a remoção de organismos patogênicos incluindo protozoários, bactérias e vírus.

As membranas de microfiltração e ultrafiltração são eficientes para remover o material orgânico responsável pela turbidez da água. Além da remoção de contaminantes biológicos, estas membranas removem também contaminantes que englobam todas as substâncias ou partículas não biológicas como: 
- carbono orgânico dissolvido de baixa massa molar;

- $\quad$ substâncias solúveis que dão cor inaceitável para os padrões de consumo;

- $\quad$ toxinas solúveis de algas;

- $\quad$ metais pesados reduzidos como, por exemplo, manganês e ferro;

- $\quad$ sais de cálcio e magnésio que aumentam a dureza de água.

A nanofiltração é eficiente na remoção de carga orgânica, uma vez que consegue separar os íons monovalentes e bivalentes agregados no material orgânico, dificultando assim a remoção do cloreto de sódio, que sozinhos podem passar livremente pelos poros das membranas utilizadas neste processo (PETERS, 1998).

A osmose reversa é utilizada para dessalinizar águas com salinidade elevada. O chorume produzido em aterro sanitário usualmente contém alta concentração de sais, cuja pressão osmótica é de 2 a 10 bar. Portanto, o valor tende a aumentar durante o processo, sendo necessário operar com elevada pressão. O processo utilizando osmose reversa para o tratamento do chorume tem sido empregado na Alemanha com grande eficiência, utilizando uma pressão de operação de 120 bar (URASE, et al., 1997).

AMOKRANE et al., (2004), em seus estudos verificou, para um chorume pré-tratado por microfiltração e ultrafiltração, que a osmose reversa remove $95 \%$ de DQO e sólidos dissolvidos totais. Em toda a Europa, o tratamento de chorumes provenientes de aterros, com 10 anos ou mais, utilizando, processos biológicos de degradação, tratamento físico-químico e adsorção por carvão ativado mostraram-se pouco efetivos.

\subsubsection{EVAPORAÇÃO}

Técnica que consiste na utilização de tanques abertos para evaporação do chorume. Em lugares com alto índice pluviométrico usam-se instalações cobertas para que também ocorra a evaporação durante o período chuvos. A ocorrência de aumento da concentração de sais solúveis, tais como 
cloreto de sódio, pode conduzir a níveis inibidores à ação microbiana sobre o resíduo não evaporado.

O mau cheiro é uma das desvantagens apresentada pela implantação desta técnica (TCHOBANOGLOUS et al., 1993). Outra desvantagem, passiva de correção, é a emissão de amônia para a atmosfera, durante o processo de evaporação do chorume. Estudos como o de Aguiar et al. (2007) analisam o efeito da acidificação do chorume antes de sua evaporação, comprovando eficiência na diminuição da emissão de amônia.

\subsubsection{RECIRCULAÇÃO}

A recirculação do chorume é considerada por alguns autores um método de tratamento. Reduz o volume por evaporação, aumenta a degradação anaeróbia no interior do aterro com a conversão dos ácidos orgânicos em $\mathrm{CH}_{4} \mathrm{e}$ $\mathrm{CO}_{2}$, promovendo a melhor distribuição de nutrientes e umidade. É uma técnica que se adapta às condições ambientais do Brasil, como temperatura, ventos e irradiação solar que favorecem a evaporação (ANDRADE, 2001).

O tratamento do chorume bruto através da recirculação, no entanto, não é totalmente adequado, uma vez que pode provocar a crescente acidificação ou alcalinização do meio bacteriano, inviabilizando o tratamento. Por outro lado, estudos mostraram que esta técnica aumentou a eficiência de compactação do aterro, facilitando o reaproveitamento posterior do terreno, e a recirculação é capaz de reduzir o tempo necessário para estabilização do aterro desde algumas décadas para 2 ou 3 anos (REINHART \& YOUSFI, 1996).

\subsubsection{NEUTRALIZAÇÃO}

A neutralização é um método de tratamento mais simples e comum para contaminantes inorgânicos, que envolve adição de ácidos ou bases para ajustar o pH em níveis aceitáveis entre 6-9. É uma reação que produz sais 
solúveis e insolúveis, sendo usada no tratamento de chorume, para acondicioná-la para outras etapas de tratamento. (ROCCA et al., 1993).

\subsubsection{TRATAMENTO ELETROQUÍMICO}

Usado para recuperação de metais, consiste na passagem de uma corrente elétrica entre dois eletrodos (ROCCA et al., 1993).

TSAI (1997), utilizou em seus estudos dois pares de eletrodos para remover a matéria orgânica do chorume, conseguindo remover moléculas pequenas e grandes, através de placas de eletrodos de aço carbono, positivas e negativas, Fe-Cu e Al-Cu obtendo para ambos os casos remoções na faixa de 30$50 \%$ para a DQO.

O processo eletrolítico representa uma tecnologia em crescente utilização, capaz de remediar alguns efluentes de diversas origens e devido às suas características favoráveis para oxidação de compostos orgânicos, aliada ao fato de a fotocatálise heterogênea estar se mostrando muito eficiente também para a remoção de cor e odor (MORAES \& BERTAZZOLI, 2005).

O tratamento eletrolítico pode sanar certas dificuldades do tratamento biológico, na medida em que oferece versatilidade quanto ao volume e variabilidade do efluente a ser tratado, fácil automação, pouco tempo de tratamento e áreas pequenas onde pode ser instalado.

\subsubsection{WETLANDS}

São caracterizados por serem ecossistemas artificiais que se encontram parcial ou totalmente inundados durante o ano, e tem como princípio básico a modificação da qualidade da água que ocorre nos Wetlands naturais como várzeas dos rios, igapós da Amazônia, banhados, pântanos, manguezais, formações lacustres de baixa profundidade em parte ou no todo, as grandes ou pequenas áreas com lençol freático muito alto, porém, nem sempre com afloramento superficial, e outros. Esses sistemas apresentam uma ação 
depuradora devido à absorção de partículas pelo sistema radicular das plantas, pela absorção de nutrientes e metais pelas plantas, pela ação de microorganismos associados à rizosfera. O fenômeno da evapotranspiração também contribui para a redução do volume produzido. É considerado economicamente viável, mas o alto teor de amônia encontrado no chorume pode prejudicar o sucesso desta técnica quando empregada como única forma de tratamento. É indicado que se use como um polimento final, após um tratamento biológico, para promover a remoção adicional da matéria orgânica e da amônia, além de promover a desnitrificação (MANNARINO et al., 2006).

Os sistemas que utilizam plantas aquáticas emergentes têm vegetação desenvolvida de tal forma que o sistema radicular encontra-se preso ao sedimento e o caule e as folhas parcialmente submersas. A profunda penetração do sistema radicular permite atingir vários níveis ao longo da camada de sedimentos, dependendo da espécie considerada (CAMPOS, 2002).

Diversas plantas vêm sendo utilizadas em wetlands construídos para tratamento de chorume: Bolbolschoenus maritimus, Gyceria máxima, Íris psçeudacorus, Juncus geradii spp., Leymus arenarius, Phalaris arundinacea, Phragmites austrais, Puccinellia capilaris, Schenoplectus laustris, Schenoplectus tabernaemontani, Thypha latifólia, Triglochin maritimum, entre outras (MAURICE, \& LAGER, 1999).

MAURICE, \& LAGER op. cit., (1999) destaca a taboa (Thypha sp.) como própria para utilização em wetlands por sua estrutura interna ser formada por tecidos que contém espaços abertos denominados aerenchyma que, nas folhas e nas raízes, são maiores enquanto que, nos rizomas, possuem aparência esponjosa. Esses espaços abertos são importantes, pois permitem o transporte do oxigênio da atmosfera para as folhas e daí para as raízes e rizomas. Parte do oxigênio pode ainda sair do sistema radicular para a área em torno da rizosfera criando condições de oxidação para os sedimentos, para decomposição aeróbia da matéria orgânica, bem como para crescimento de bactérias nitrificantes (MAURICE, \& LAGER op. cit, 1999; CAMPOS op. cit., 2002) 
A remoção de poluentes nos wetlands envolve uma complexidade de processos físicos, químicos e biológicos que ocorrem simultaneamente. Os processos de tratamento incluem sedimentação, filtração, precipitação, sorção, decomposição, microbiológica, nitrificação e desnitrificação (KADLEC, 1998).

Os íons nitrato são absorvidos pelos vegetais como nutrientes e, sob a ação de bactérias desnitrificantes, em sítios anóxidos no interior dos wetlands, e transformados novamente em nitrogênio molecular, possibilitando seu retorno para a atmosfera.

Nos chorumes, o fósforo apresenta-se predominantemente sobre a forma de ortofosfatos, que é a forma mais estável no meio aquoso. A remoção do mesmo está ligada à adsorção em argilominerais, em certas frações orgânicas do solo e à precipitação química com metais como cálcio, ferro e alumínio (FERREIRA et al., 2005).

\subsubsection{REMOÇÃO DE METAIS PESADOS}

Metais pesados como chumbo, mercúrio, cromo, níquel, zinco, dentre outros, estão presentes em diversos tipos dos resíduos levados para aterros industriais e sanitários. Podem ser encontrados em: lâmpadas, pilhas, baterias, resto de tintas, resto de produtos de limpeza, óleos lubrificantes usados, solventes, embalagens de aerossóis, resto de amálgama utilizada em consultórios odontológicos, materiais fotográficos e radiográficos, embalagens de produtos químicos, pesticidas, fungicidas, e inseticidas, componentes eletrônicos descartados isoladamente em placas de circuitos impressos, resíduos de produtos farmacêuticos, medicamentos com prazos de validade vencidos, latarias de alimentos, aditivos alimentares, e plásticos descartados.

A técnica mais usada para a remoção de metais pesados é a precipitação química, utilizando hidróxidos, cal ou soda cáustica, que são as 
formas mais usadas, enquanto que a precipitação com sulfeto apresenta maior custo e pode gerar gás sulfídrico.

No caso dos chorumes, a concentração de metais depende do tipo de lixo depositado no aterro, sendo relativamente baixa para o lixo doméstico, podendo aumentar para os despejos industriais. Ela pode variar de acordo com o estágio de decomposição do lixo, sendo maior durante a fase de fermentação ácida, quando estes elementos estão mais solúveis e menor nas últimas fases de estabilização, quando o pH é mais alcalino (SISINO, 1995).

Em certas condições de disposição de resíduos, como "lixão a céu aberto" ou "aterro controlado", a elevada concentração de metais presente no chorume pode causar grande impacto nos corpos de água circunvizinho. Nesses sistemas de disposição não controlados, ainda muito utilizados em vários municípios do Brasil, os metais pesados podem ser percolados por meio do chorume, que se mistura com água de chuva e outros líquidos, originalmente existentes no lixo, infiltrando-se no solo e subseqüentemente, contaminando a água subterrânea. A contaminação dessas águas tem conseqüências que perduram por tempo indefinido e são de difícil controle.

Os metais pesados encontrados estão presentes tanto na forma dissolvida, mais facilmente incorporada pela fauna e flora, quanto na forma particulada associados a partículas em suspensão.

Para definir os limiares de toxicidade dos contaminantes químicos, em geral, como primeiro passo, devem ser calculados os valores normais que apresentam as matrizes não contaminadas (solo, água, vegetação, alimentos). A partir dessa base podem-se estabelecer os níveis mínimos que representam contaminação e os níveis de toxicidade definidos, levando em consideração os possíveis efeitos em vegetais, animais, e principalmente, os potenciais agravos para a saúde humana. Para reconhecimento da contaminação são utilizados "níveis de referência" que conduzem a sistemas de alerta, vigilância e controle. Acima desses níveis encontram-se os níveis de intervenção que obrigam tomada de medidas corretivas (GARCIA \& DORRONSORO, 2002). 
Considerando especificamente os metais pesados, a maioria das normas são referidas à quantidade total do elemento tóxico, dada a dificuldade de extração de metais, supondo que existe equilíbrio entre as fases solúvel e a concentração total. Calcula-se que $10 \%$ do total encontram-se em fase solúvel (LINDSAY, 1979 apud Garcia \& Dorronsoro op. cit, 2002). Existe o consenso de que a concentração na fase assimilável é uma medida direta do grau de perigo real, enquanto que a concentração total é válida para avaliar o risco potencial ou futuro, representando uma maneira indireta de estimar a toxicidade atual do solo (GARCIA \& DORRONSORO op. cit, 2002).

Cada compartimento ambiental apresenta uma limitada capacidade de suportar a ação dos metais, que ameaçam o ecossistema e conseqüentemente podem atingir o homem pelo acúmulo na cadeia alimentar (SISINO, 1995).

\section{8 - GERAÇÃO DE GASES}

Outro problema ambiental no aterramento de resíduos refere-se à emissão de gases, formados pela decomposição do material orgânico. Os principais constituintes desses gases são dióxido de carbono e metano, sendo este último, combustível que pode ser coletado e utilizado como fonte de energia.

Segundo TCHOBANOGLOUS, THEISEN \& VINIL (1993) e USEPA (1996) a formação do gás nos aterros, depende da composição dos resíduos (quanto maior a porcentagem de material orgânico, maior o potencial de geração de metano), ambientes anaeróbios (essencial para a produção do metano), umidade (essencial à vida das bactérias decompositoras), acidez e temperatura (metanogênicas atingem maior produtividade a pH entre 6,8 e 7,2 e temperaturas entre $50^{\circ} \mathrm{C}$ e $\left.60^{\circ} \mathrm{C}\right)$.

TABASARAN (1982) e GUNNERSON \& STUCKEY (1986) apud BINGEMER \& CRUTZEN (1987), acreditam que a pequena diferença existente entre a concentração de metano e dióxido de carbono encontrada no biogás se 
deve à dissolução de parte do $\mathrm{CO}_{2}$ na fração aquosa da massa de resíduo. $\mathrm{O}$ QUADRO 2.8 apresenta os valores aproximados da composição do biogás.

QUADRO 2.8 - Composição básica de biogás produzido nos aterros sanitários

\begin{tabular}{|c|c|}
\hline Composição & Porcentagem (base seca) \\
\hline Metano & $45-60$ \\
\hline Dióxido de carbono & $40-60$ \\
\hline Nitrogênio & $2-5$ \\
\hline Oxigênio & $0,1-1,0$ \\
\hline Enxofre & $0-1,0$ \\
\hline Amônia & $0,1-1,0$ \\
\hline Hidrogênio & $0-0,2$ \\
\hline Monóxido de carbono & $0-0,2$ \\
\hline Gases em menores concentrações & $0,01-0,6$ \\
\hline
\end{tabular}

Fonte: Tchobanoglous, Theisen \& Vinil, 1993

Dentre os principais problemas locais da emissão descontrolada de biogás, advinda da decomposição do lixo, estão os prejuízos causados à saúde humana e à vegetação, decorrentes da formação de ozônio de baixa altitude ou da exposição a alguns constituintes do biogás que podem causar câncer e outras doenças que atacam fígado, rins, pulmões e sistema nervoso central. Há ainda o risco de incêndios e explosões em instalações próximas aos aterros, uma vez que este gás é altamente inflamável (ENSINAS, 2003).

O gás metano gerado nos aterros, quando não coletado de forma devida, contribui para o agravamento do efeito estufa, indicando não somente uma preocupação com a integridade da região onde é gerado, como também está ligado às questões ambientais globais (ENSINAS op. cit., 2003). 
Nos aterros que queimam o biogás nos próprios drenos, normalmente, a eficiência da queima é baixa, devido à precariedade construtiva e operacional desses drenos (ZULAUF, 1983).

Um outro problema da queima do gás metano nos drenos refere-se aos períodos de chuva onde ocorrem erosões de cobertura e no período seco, trincas no solo de cobertura. Essas ocorrências promovem significativa perda do gás gerado, que se dissipa rapidamente para a atmosfera, promovendo escapes de metano e dissipando gases de odores indesejáveis pela região do aterro (MMA, 2004).

A forma mais adequada de destruir com grande eficiência o metano do biogás é queimá-lo em "flare" enclausurado com tempo de retenção e temperatura suficiente para atingir mais de 98\% de oxidação (MMA op. cit., 2004).

Segundo International Panel on Climate Change (IPCC, 1996) os aterros são responsáveis por cerca de 5\% a 20\% do total de metano liberado por fontes com origem antrópicas, contribuindo assim para o agravamento do efeito estufa.

Estima-se que no Brasil a emissão do gás metano para a atmosfera, gerado pela decomposição de resíduos sólidos, em 1990 foi de 618000 toneladas, aumentando para 677000 toneladas no ano de 1994 (VIEIRA \& ALVES, 2002). Com o advento da venda de créditos de carbono apresentado no Protocolo de Kyoto, projetos já vêem ocorrendo aqui no Brasil para captação do gás metano (CETESB, 2006).

Para que o aterro seja considerado como fonte viável para captação de metano para fins energéticos, é necessário pelo menos um milhão de toneladas de resíduos (USEPA, 1996). O tempo para que ocorra a geração do metano pode ser estimada com base na composição química e velocidade de degradação dos resíduos aterrados (ALVES, 2000 \& HAMADA,1997 In: CETESB, 2006). 


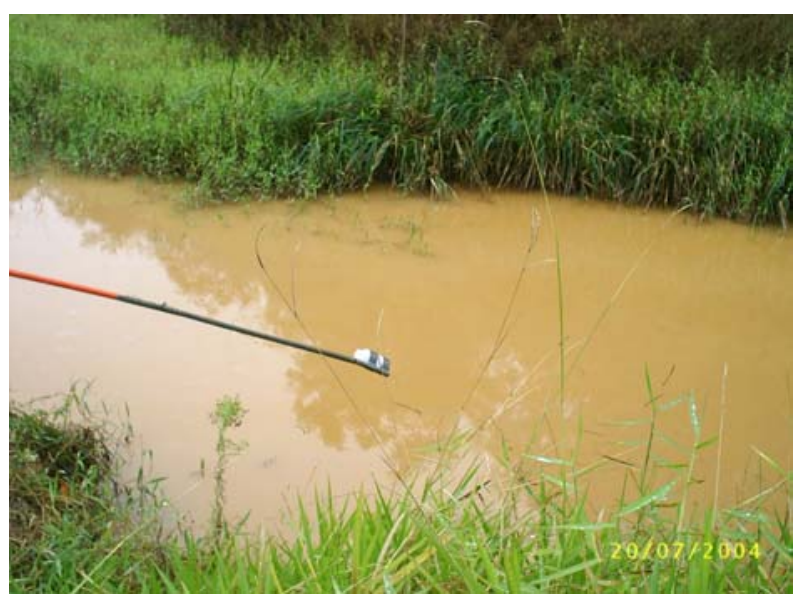

\section{CAPÍTULO II}
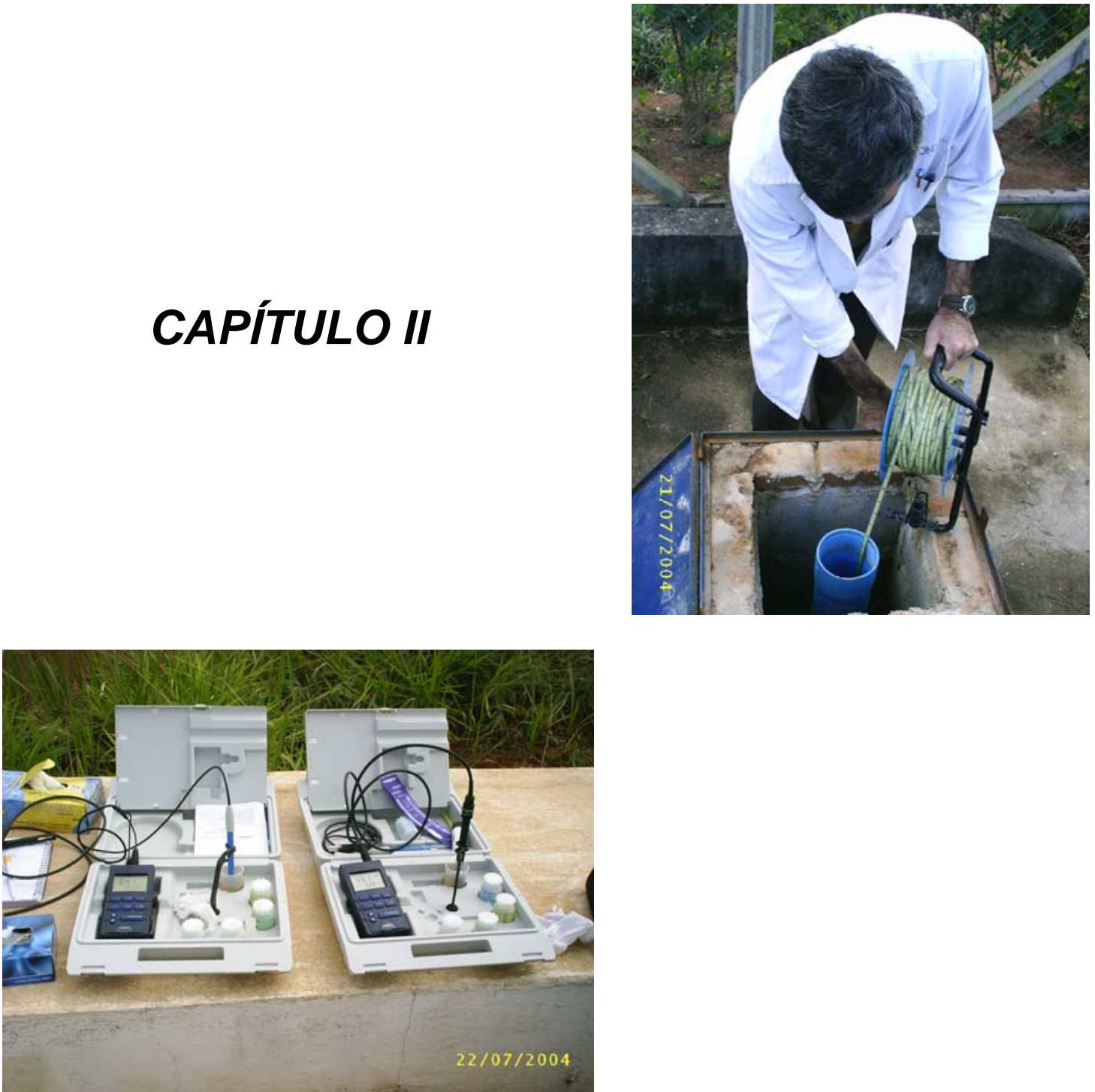

Amostragem e medidas de parâmetros físicos e físico-químicos das amostras de águas superficiais e subterrâneas da área de estudo 


\section{3 - OBJETIVOS}

Estudar o comportamento geoquímico dos principais íons metálicos associados ao solo, solo/sedimento, sedimento de fundo, águas subterrânea e superficial - alumínio, ferro, manganês e chumbo - numa área onde se encontram três Aterros Sanitários e um Industrial bem como seu entorno, localizados no Município de Tremembé, SP;

Propor medidas de reaproveitamento do chorume gerados em aterros sanitários. 


\section{4 - LOCALIZAÇÃO E CARACTERIZAÇÃO DA ÁREA DE ESTUDO}

\section{1 - LOCALIZAÇÃO E ACESSOS AOS ATERROS}

Os Aterros em estudo localizam-se na Estrada Municipal 2 200, no Bairro Mato Dentro, no Município de Tremembé, SP (FIGURA 4.1), com coordenadas geográficas Lat $22^{0} 57^{\prime} 45$ e Long $45^{0} 33^{\prime} 17$. Os acessos podem ser realizados pelas Rodovias SP-070 Ayrton Senna, pela BR-116 Rodovia Presidente Dutra e SP-123 Rodovia Floriano Rodrigues Pinheiro.

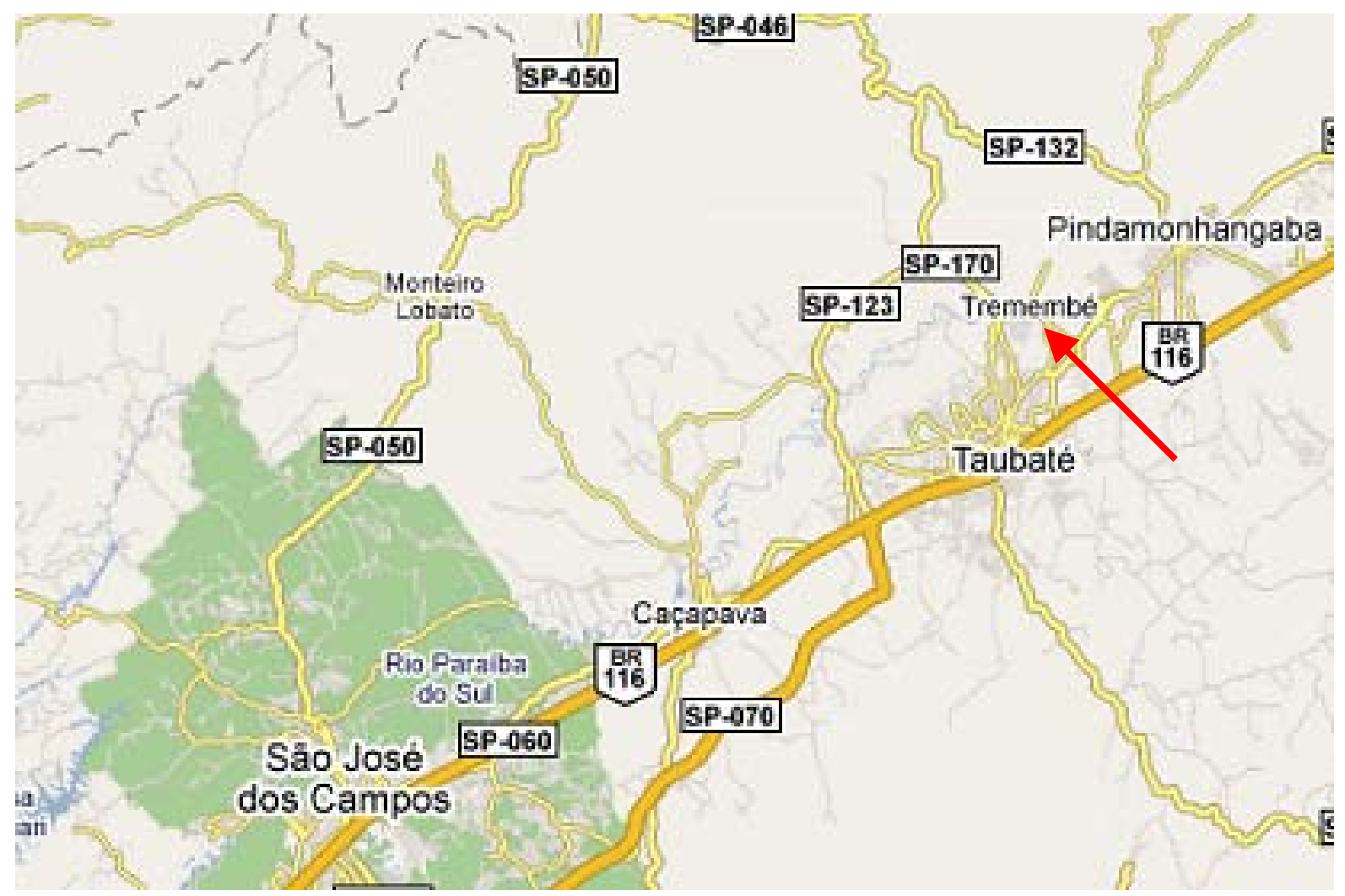

FIGURA 4.1 - Acessos da área de estudos no Município de Tremembé - SP.

Fonte: www.maps.google.com.br 


\section{2 - GEOLOGIA}

O contexto geológico em que se insere a área de estudo apresentase na FIGURA 4.2 situada no complexo cristalino Pré-Cambriano do Leste Paulista, no Bloco Tectônico Paraíba do Sul, limitados pela Falha do Buquira ao norte e ao sul pela Falha do Alto da Fartura. Outras falhas de menor porte são reconhecidas nessa região, como a Falha da Serra do Jambeiro, Falha do Bom retiro, Falha de Pinheiros, Falha do Ronco, entre outras (HASUl et al., 1978).

A Bacia de Taubaté faz parte de um conjunto de bacias tafrogênicas, dispostas sobre uma faixa orientada segundo a direção ENE, subparalela aos principais traços estruturais e geomorfológicos da Região Sudeste do Brasil, denominado "Sistema de Rifts da Serra do Mar" (ALMEIDA, 1976) e, atualmente, "Rift Continental do Sudeste do Brasil" (RICCOMINI, 1989).

A coluna estratigráfica da Bacia de Taubaté está subdividida em três ciclos básicos de sedimentação, apoiados no reconhecimento dos sistemas deposicionais e de suas fácies geneticamente associadas. Estas seqüências foram designadas, da base para o topo, em seqüências Tremembé, Taubaté e Paraíba do Sul (CAMPANHA, 1994).

Os sistemas deposicionais da Bacia de Taubaté são representados pelos leques aluviais que gradam para sistemas fluviais entrelaçados e meandrantes, assim como para sistemas lacustres (CAMPANHA, op. cit., 1994). 


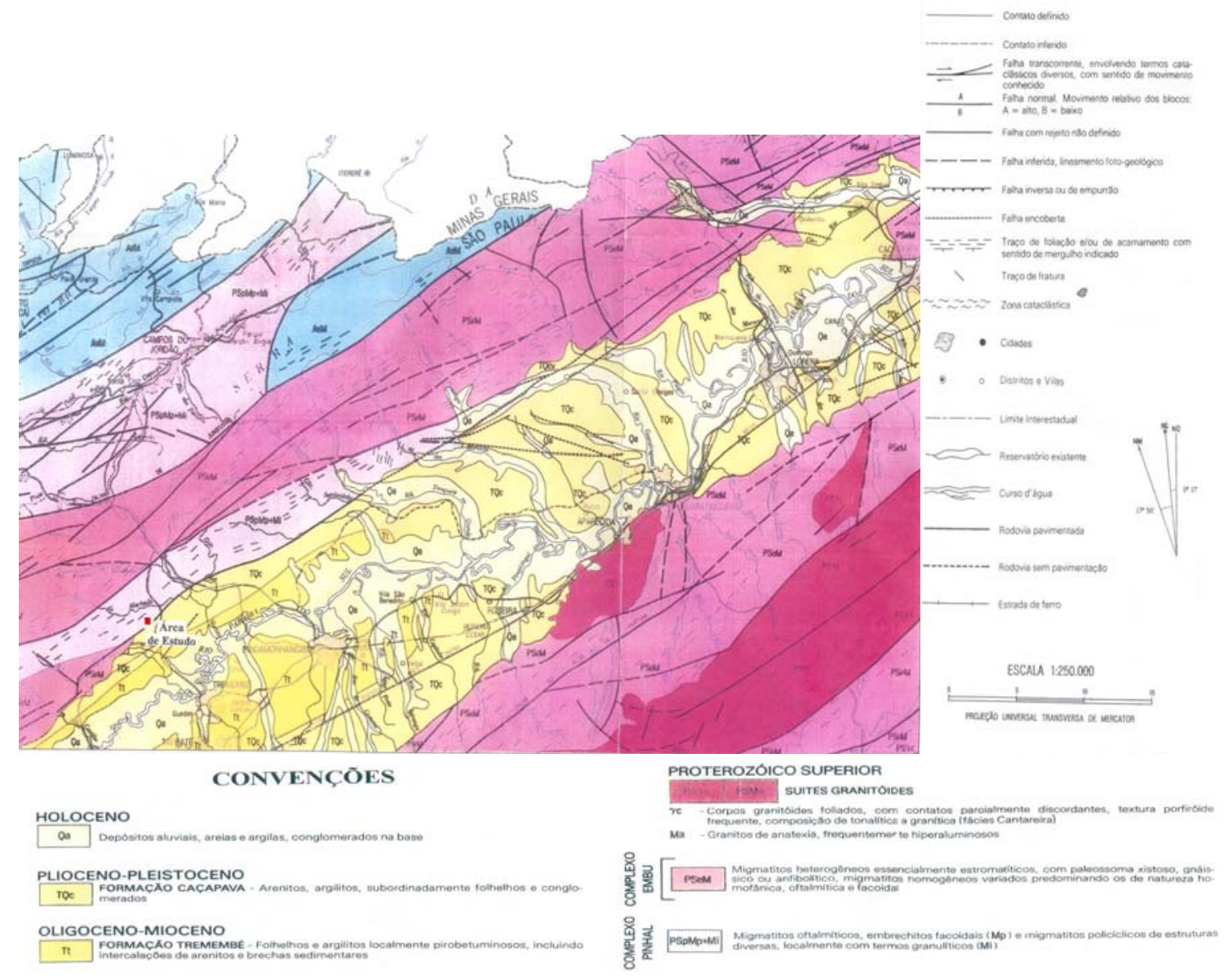

FIGURA 4.2 - Geologia da área de Estudo 


\section{3 - HIDROGEOLOGIA}

O principal rio de Tremembé é o Paraíba, que corta o Município de leste a oeste. Seus afluentes são o Rio Una, o Piracuama e o Rio Verde, este com nascente no próprio Município.

A área de estudo compreende basicamente três sistemas aqüíferos: Coberturas Sedimentares Cenozóicas, Taubaté e Cristalino (CETESB, 1997), cujas principais características estão no QUADRO 4.1.

QUADRO 4.1 - Principais características dos aqüíferos locais

\begin{tabular}{|c|c|c|c|}
\hline Aqüífero & $\begin{array}{c}\text { Coberturas } \\
\text { Cenozóicas }\end{array}$ & Taubaté & Cristalino \\
\hline $\begin{array}{c}\text { Características } \\
\text { hidrogeológicas } \\
\text { principais }\end{array}$ & $\begin{array}{c}\text { Extensão regional; } \\
\text { fissurado; } \\
\text { descontínuo; } \\
\text { heterogêneo; }\end{array}$ & $\begin{array}{c}\text { Extensão limitada; } \\
\text { granular; livre; } \\
\text { descontínuo; } \\
\text { heterogêneo; }\end{array}$ & $\begin{array}{c}\text { Extensão limitada; } \\
\text { granular; livre e } \\
\text { semiconfinado; } \\
\text { descontínuo; } \\
\text { heterogêneo; }\end{array}$ \\
\hline Unidade geológica & Qa & T Qa & PS e M \\
\hline $\begin{array}{c}\text { Espessura média } \\
(\mathrm{m})\end{array}$ & 200 & 500 & 30 \\
\hline $\begin{array}{c}\text { Vazão média por } \\
\text { poço }\left(\mathrm{m}^{3} \mathrm{~h}^{-1}\right)\end{array}$ & 5 a 30 & 15 a 20 & 1 a 30 \\
\hline pH & Ácido a neutro & 4,5 a 8,5 & - \\
\hline
\end{tabular}

Fonte: Cetesb, op. cit., 1997

Os terrenos sedimentares cenozóicos formam o principal e melhor aqüífero da região; suas características não são uniformes variando segundo a litologia do pacote sedimentar (DAEE, 1979).

As rochas cristalinas ígneas e metamórficas do Pré-Cambriano não formam um aqüífero regional, contudo, apresentam localmente condições aqüíferas e, por conseqüência, são explorados por algumas dezenas de poços.

O Grupo Taubaté é composto pelas Formações Resende, São Paulo e Tremembé. Esta é constituída predominantemente por folhelhos, em parte pirobetuminosos, argilitos e incluem fósseis (peixes, penas de aves, morcegos, 
crocodilídeos, carapaças de quelônios, crustáceos e plantas). Intercalações de arenitos conglomeráticos e arcóseos também estão presentes (MANCINI, 1995).

\section{4 -Vegetação, Pedologia e Clima}

A área acha-se em situação de Domínio de Mata Atlântica, sendo que parte encontra-se sob as Fitofisionomias (formação florestal) savana e estacional semidecidual. Está em setor definido como Zona de Transição entre o Vale do Rio Paraíba do Sul e a Serra da Mantiqueira (IBGE, 1983).

O tipo de solo predominante na região é classificado como Podzólicos e Latossolo Vermelho e Amarelo (EMBRAPA, 1981). Seu uso refere-se à aqüicultura, avicultura, pecuária, principalmente leiteira e rizicultura, sendo a maioria das propriedades de pequeno e médio portes.

O relevo é ondulado e suavemente ondulado, caracterizado por mar de morros e várzea (WAMBEKE, 1981).

O regime hídrico é caracterizado como Perúdico (com muita chuva) e o regime térmico dos solos classifica-se como isoipertérmico com profundidade média de $50 \mathrm{~cm}$. O índice pluviométrico anual está em torno de $1430 \mathrm{~mm}$ (WAMBEKE op. cit, 1981).

A FIGURA 4.3 mostra a variação média da pluviometria mensal da região, no ano de 1994 (www.daee.sp.gov.br).

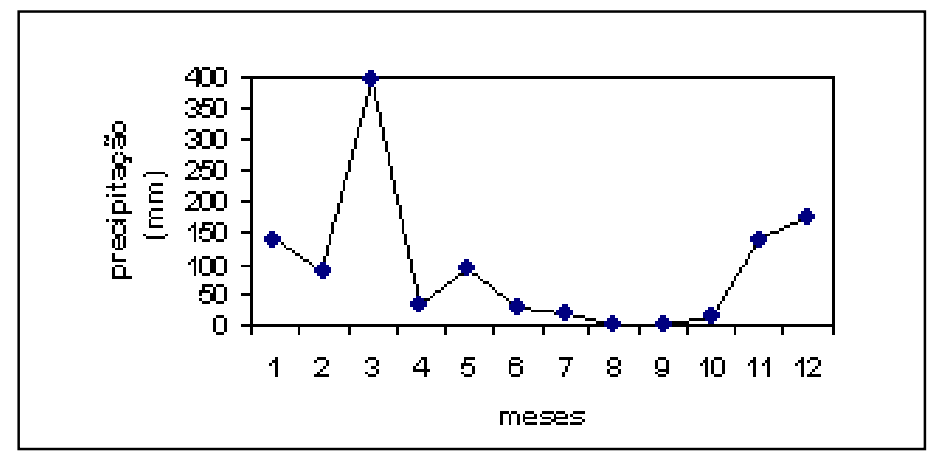

FIGURA 4.3 - Variação da média mensal da pluviometria da área de estudo. 
O clima é considerado mesotérmico com temperaturas médias anuais inferiores à $18{ }^{\circ} \mathrm{C}$ nos meses frio (junho e julho) e superiores à $25^{\circ} \mathrm{C}$ nos meses quentes (janeiro e fevereiro), resultando na média de $24,7^{\circ} \mathrm{C}$.

\section{5 - Dados Sócio-Econômicos}

A área total do Município de Tremembé é de aproximadamente $184 \mathrm{~km}^{2}$, sendo $24 \mathrm{~km}^{2}$ correspondente à área urbana e o restante à área rural (www.tremembe.sp.gov.br).

A população atual é de 34703 habitantes sendo aproximadamente 4000 pertencentes à área rural.

As atividades econômicas são principalmente a agricultura, pequenas empresas e serviços (IBGE, 2000). 


\section{5 - AMOSTRAGEM}

A área de estudo corresponde a três Aterros Sanitários (A, B e C) e um Industrial (D). Os Aterros A e $\mathbf{B}$ pertencem à classe IIB, o Aterro $\mathbf{C}$ à classe IIA e o $\mathbf{D}$ à classe $\mathrm{I}$.

Por proibição do acesso aos Aterros, imposta pela Empresa, foi realizada apenas uma campanha, no período chuvoso, que possibilitou amostragens de solo, solo/sedimento, sedimento de fundo e águas superficiais e subterrâneas.

\section{1 - SOLOS}

As amostras de solo foram coletadas, ao redor dos Aterros, utilizando trado manual tipo holandês com 3" de diâmetro (FIGURA 5.1). As coletas foram efetuadas conforme mudanças litológicas do perfil, variando de 0 até $65 \mathrm{~cm}$ de profundidade e acondicionadas em sacos de polietileno lacrados e rotulados.

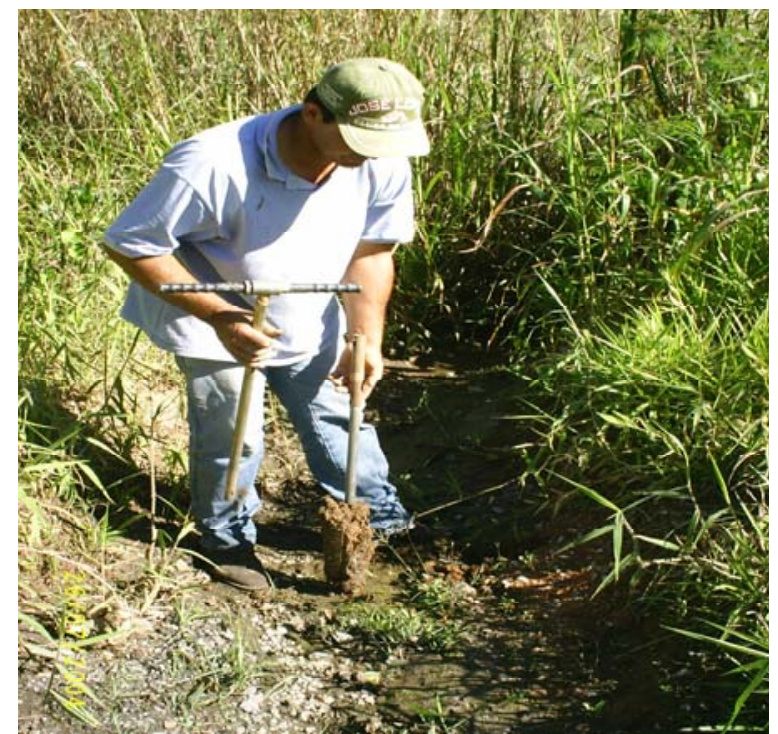

FIGURA 5.1 - Amostragem de solo do entorno dos Aterros 
No interior da Empresa as amostras de solo foram coletadas em um antigo leito de secagem de resíduos $\left(\mathbf{S}_{\mathbf{1}}\right)$.

Foram também obtidas amostras de solo em locais próximo aos pontos de amostragem de solo/sedimento do Rio Serragem, $\mathbf{S}_{\mathbf{2}}$ e $\mathbf{S}_{\mathbf{3}}$. Este Rio é receptor de um córrego que passa pela área dos Aterros.

\section{2 - SOLOISEDIMENTO}

Com auxílio de um amostrador improvisado foram coletadas amostras de solo/sedimento no afluente do Rio Serragem ( $\left.\mathbf{R}_{\mathbf{S} 4}\right)$ que passa por dentro da área onde estão localizados os Aterros e em outros três pontos do mesmo Rio ( $\left.\mathbf{R}_{\mathbf{S} 1}, \mathbf{R}_{\mathbf{S} 2} \mathbf{e} \mathbf{R}_{\mathbf{S} 3}\right)$ externo à área dos Aterros, localizados antes, na foz e depois do afluente. Tomados como referência, coletaram-se amostras do Rio Pimenta $\left(\mathbf{R}_{\mathbf{S 5}}\right)$ situado externamente à área de influência dos Aterros.

\section{3 - SEDIMENTO DE FUNDO}

Coletaram-se também amostras de sedimento de fundo associados às nascentes que abastecem o Lago (Ls1) localizado próximo ao Aterro $\mathbf{D}$.

\section{4 - ÁGUAS SUBTERRÂNEAS}

As técnicas de amostragens das águas subterrâneas (FIGURA 5.2) foram baseadas em normas da CETESB (2005) e American Public Health Association (APHA, 1995). 

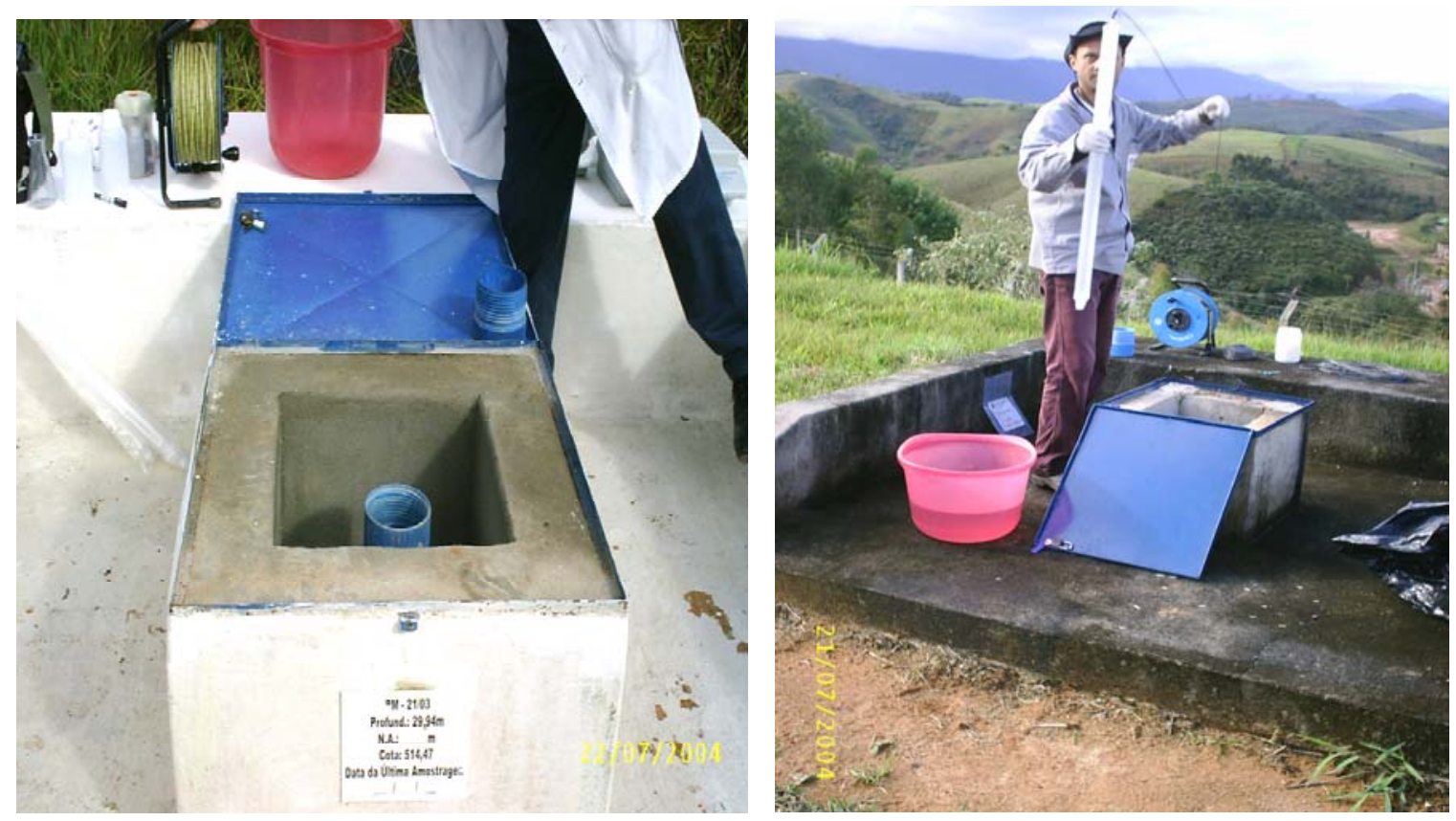

FIGURA 5.2 - Foto do poço de monitoramento e amostragem de água subterrânea com o auxílio do amostrador do tipo bailer.

As amostras líquidas, no momento da coleta, foram filtradas (milipore de $0,45 \mu \mathrm{m})$ e acondicionadas em frascos de polietileno com agentes preservantes. Alíquotas de cada amostra, sem a adição dos preservantes, foram mantidas em caixas termoisolantes a temperatura de $4^{\circ} \mathrm{C}$.

Foram coletadas amostras de águas em poços de monitoramento $\mathbf{A}_{\mathrm{A} 1}$ e $\mathbf{A}_{\mathrm{A} 2}$ associados ao Aterro $\mathbf{A} ; \mathbf{A}_{\mathrm{B} 1}$ e $\mathbf{A}_{\mathrm{B} 2}$ ao Aterro $\mathrm{B} ; \mathbf{A}_{\mathrm{C} 1}$ e $\mathbf{A}_{\mathrm{C} 2}$ ao Aterro $\mathbf{C}$ e os demais pontos, $A_{D 1}, A_{D 2}, A_{D 3}, A_{D 4}, A_{D 5}, A_{D 6}, A_{D 7}$ e $A_{D 8}$, associados ao Aterro D. 


\section{5 - ÁGUAS SUPERFICIAIS}

As águas superficiais foram coletadas e armazenadas em fracos de polietileno (FIGURA 5.3) seguindo orientações preconizadas pela CETESB (2005) e APHA (1995) e preservadas igualmente ás águas subterrâneas.

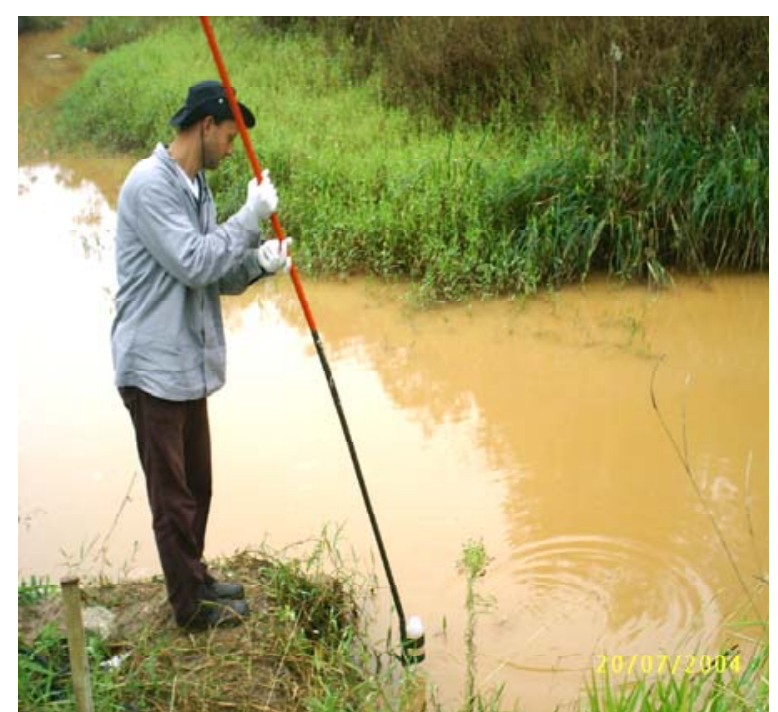

FIGURA 5.3 - Amostragem de água superficial do afluente do Rio Serragem que sofre interferência direta dos Aterros

Dentro da área da Empresa foi coletada amostra de água superficial de um afluente do Rio Serragem $\left(\mathbf{R}_{\mathbf{a} 4}\right)$.

Coletaram-se ainda amostras de águas do Rio Serragem $\left(\mathbf{R}_{\mathrm{a} 1}, \mathbf{R}_{\mathrm{a} 2} \mathbf{e}\right.$ $\mathbf{R}_{\mathbf{a} 3}$ ), uma delas onde deságua o córrego que passa dentro da área onde estão os Aterros e outras duas antes e depois desta foz.

Finalmente, no entorno dos Aterros foram coletadas amostras de águas das nascentes $(\mathbf{N})$ que formam o Lago que abastecem um ranário próximo ao Aterro $\mathbf{D}$ bem como do Lago (L). Coletaram-se também, como referência, águas do Rio Pimenta $\left(\mathbf{R}_{\mathbf{r}}\right)$ que não apresenta ligação direta com os Aterros. 
Por ocasião das coletas de águas foram medidos alcalinidade (HYPOLITO et al., 2008), pH (com eletrodos de vidro) e Eh (com eletrodo combinado de platina, modelo multiline P3 - marca WTW) e para leituras da condutividade elétrica (CE), temperatura e oxigênio dissolvido (OD) foram usados eletrodos P3/oxi/cond. - marca WTW.

Na FIGURA 5.4 são apresentados os pontos de amostragem, bem como o sentido de fluxo das águas subterrâneas. 


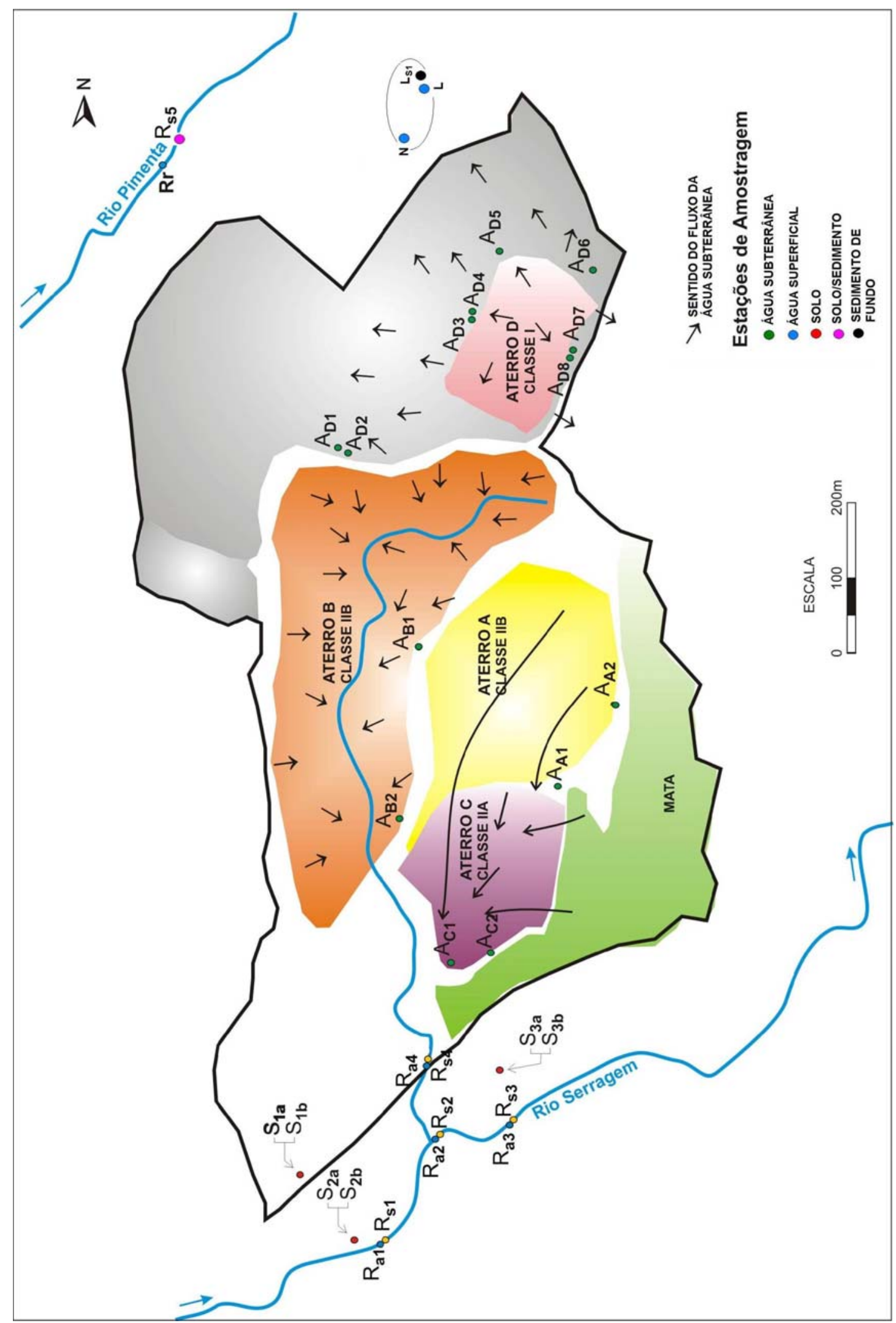

FIGURA 5.4 - Pontos de amostragem e sentido do fluxo das águas subterrâneas 


\section{6 - Parâmetros Químicos e Físico-Químicos Medidos em Campo}

A concentração de íons metálicos em águas naturais acha-se intimamente associado aos fenômenos de sorção (adsorção e absorção) e dessorção. Estes fenômenos, por sua vez, encontram-se na dependência de parâmetros como $\mathrm{pH}$, potencial redox, condutividade elétrica e alcalinidade que foram medidos em campo e apresentados nas TABELAS 6.1 e 6.2.

TABELA 6.1 - Dados químicos e físico-químicos das águas subterrâneas da área dos Aterros A, B, C e D.

\begin{tabular}{|c|c|c|c|c|c|c|c|c|c|c|c|c|c|c|}
\hline $\begin{array}{r}\begin{array}{r}\text { Pontos de } \\
\text { amostragem }\end{array} \\
\text { Parâmetros }\end{array}$ & $A_{A 1}$ & $A_{A 2}$ & $A_{B 1}$ & $A_{B 2}$ & $A_{C 1}$ & $A_{C 2}$ & $A_{D 1}$ & $A_{D 2}$ & $A_{D 3}$ & $A_{D 4}$ & $A_{D 5}$ & $A_{D 6}$ & $A_{D 7}$ & $A_{D 8}$ \\
\hline N.A. (m) & 12,56 & 19,00 & 19,05 & 12,46 & 17,06 & 14,87 & 16,00 & 16,26 & 24,20 & 23,13 & 38,00 & 23,50 & 28,60 & 28,04 \\
\hline pH & 5,64 & 5,95 & 5,92 & 6,08 & 6,73 & 6,44 & 5,94 & 6,20 & 5,78 & 5,48 & 5,82 & 5,87 & 5,00 & 5,58 \\
\hline Eh (V) & $+0,16$ & $+0,25$ & $+0,23$ & $+0,21$ & $+0,12$ & $+0,29$ & $+0,15$ & $+0,14$ & $+0,23$ & $+0,27$ & $+0,27$ & $+0,23$ & $+0,36$ & $+0,27$ \\
\hline $\operatorname{CE}\left(\mu \mathrm{S} \mathrm{cm}^{-1}\right)$ & 62 & 89 & 50 & 19 & 45 & 18 & 33 & 53 & 27 & 10 & 23 & 26 & 15 & 18 \\
\hline $\begin{array}{l}\text { Alcalinidade } \\
\left(\mathrm{CaCO}_{3} \mathrm{mg} \mathrm{dm}^{-3}\right)\end{array}$ & 13,00 & 11,00 & 8,00 & 6,00 & 8,00 & 13,00 & 8,00 & 8,00 & 3,00 & 3,00 & 5,00 & 5,00 & 3,00 & 3,00 \\
\hline
\end{tabular}

TABELA 6.2 - Dados químicos e físico-químicos das águas superficiais da área dos Aterros e entorno

\begin{tabular}{|c|c|c|c|c|c|c|c|}
\hline $\begin{array}{r}\begin{array}{r}\text { Pontos de } \\
\text { amostragem }\end{array} \\
\text { Parâmetros }\end{array}$ & $\mathbf{R}_{\mathbf{r}}$ & $\mathbf{N}$ & $\mathbf{L}$ & $\mathbf{R}_{\mathrm{a} 1}$ & $\mathbf{R}_{\mathrm{a} 2}$ & $\mathbf{R}_{\mathrm{a} 3}$ & $\mathbf{R}_{\mathrm{a} 4}$ \\
\hline pH & 8,52 & 7,72 & 7,83 & 8,25 & 8,42 & 5,80 & 7,30 \\
\hline Eh (V) & $+0,17$ & $+0,17$ & $+0,21$ & $+0,12$ & $+0,19$ & $+0,20$ & $+0,12$ \\
\hline OD $\left(\mathrm{mg} \mathrm{dm}^{-3}\right)$ & 0,13 & 0,12 & 0,15 & 0,05 & 0,19 & 0,13 & 4,51 \\
\hline$C E\left(\mu \mathrm{cm}^{-1}\right)$ & 21 & 55 & 17 & 66 & 250 & 61 & 1185 \\
\hline $\begin{array}{l}\text { Alcalinidade } \\
\left(\mathrm{CaCO}_{3} \mathrm{mg} \mathrm{dm}^{-3}\right)\end{array}$ & 5,00 & 11,00 & 3,00 & 8,00 & 40,00 & 5,00 & 43,00 \\
\hline
\end{tabular}


MOURA, C.L. (2008). ÍONS METÁLICOS (Al, Fe, Mn e Pb) ASSOCIADOS A ATERROS (SANITÁRIO E INDUSTRIAL) NO MUNICÍPIO DE TREMEMBÉ/SP.

As amostras de águas subterrâneas apresentaram temperatura média de $21^{\circ} \mathrm{C}$, pH ligeiramente ácido com valor médio 5,90 e os potenciais de óxido-redução positivos indicando ambientes oxidantes para todas as amostras.

Os valores de alcalinidade, como era de se esperar para águas subterrâneas, apresentaram-se baixos.

A temperatura das águas superficiais variaram de $17,60{ }^{\circ} \mathrm{C}$ à $22,00{ }^{\circ} \mathrm{C}$. O pH médio foi 7,70 e Eh também positivos para todas as amostras. 


\section{7 - TRABALHOS LABORATORIAIS}

As amostras de solo, solo/sedimento e sedimento de fundo foram secas à temperatura ambiente, destorroadas, quarteadas e peneiradas para separação em frações inferiores e superiores a $2 \mathrm{~mm}$.

Foram realizados determinações de Capacidade de Troca Catiônica (CTC), pH e matéria orgânica (M.O.) do solo, solo/sedimento e sedimento de fundo efetuadas na Escola Superior de Agricultura Luiz de Queirós pelo Instituto Agronômico de Campinas (TABELA 7.1).

TABELA 7.1 - Resultados das determinações de CTC, pH e M.O. do solo, solo/sedimentos e sedimento de fundo

\begin{tabular}{|c|c|c|c|c|c|c|c|c|c|c|c|}
\hline $\begin{array}{l}\text { Amostras } \\
\text { (Prof. cm) } \\
\text { Parâmetros }\end{array}$ & $\begin{array}{c}S_{1} \\
(0-20)\end{array}$ & $\begin{array}{c}S_{1} \\
(20-50)\end{array}$ & $\begin{array}{c}\mathrm{S}_{2} \\
(0-20)\end{array}$ & $\begin{array}{c}S_{2} \\
(20-65)\end{array}$ & $\begin{array}{c}\mathrm{S}_{3} \\
(0-20)\end{array}$ & $\begin{array}{c}\mathrm{S}_{3} \\
(20-40)\end{array}$ & $\mathbf{R}_{\mathrm{S} 2}$ & $\mathbf{R}_{\mathrm{S} 3}$ & $\mathbf{R}_{\mathbf{S} 4}$ & $\mathbf{R}_{\mathbf{S} 5}$ & $\mathrm{~L}_{\mathrm{s} 1}$ \\
\hline $\begin{array}{c}\mathrm{pH} \\
\left(\mathrm{CaCl}_{2}\right)\end{array}$ & 4,1 & 4,1 & 6,4 & 4,9 & 6,0 & 5,3 & 5,1 & 4,3 & 5,6 & 5,5 & 4,2 \\
\hline $\begin{array}{l}\mathrm{pH} \\
(\mathrm{KCl})\end{array}$ & 4,0 & 3,9 & 6,1 & 4,7 & 5,7 & 5,0 & 4,7 & 4,1 & 5,4 & 5,3 & 4,1 \\
\hline$\Delta \mathrm{pH}$ & $+0,1$ & $+0,2$ & $+0,3$ & $+0,2$ & $+0,3$ & $+0,3$ & $+0,4$ & $+0,2$ & $+0,2$ & $+0,2$ & $+0,1$ \\
\hline $\begin{array}{c}\text { CTC } \\
\left(\mathrm{cmol}_{\mathrm{c}} \mathrm{kg}^{-1}\right)\end{array}$ & 3,5 & 4,1 & 55,3 & 31,0 & 34,9 & 30,5 & 32,1 & 20,3 & 8,4 & 4,9 & - \\
\hline $\begin{array}{c}\text { M.O. } \\
\left(\mathrm{g} \mathrm{kg}^{-1}\right)\end{array}$ & 2 & 1 & 8 & 6 & 18 & 6 & 27 & 45 & 1 & 1 & 24 \\
\hline
\end{tabular}

Valores positivos de $\Delta \mathrm{pH}$ indicam presença predominante de cargas negativas nas partículas coloidais, aptas a adsorverem íons metálicos.

Nota-se que a CTC do $S_{1}$, antigo local utilizado para secagem de resíduos, é relativamente baixo em relação ao solo da região $\left(\mathrm{S}_{2}\right.$ e $\left.\mathrm{S}_{3}\right)$. 


\subsection{ANÁLISES GRANULOMÉTRICAS}

As análises granulométricas qualitativas e quantitativas foram realizadas pelo Método da Pipeta de Robson (dispersão total) com eliminação prévia de matéria orgânica, seguindo os procedimentos do Laboratório de Sedimentologia - GSA/IGc da USP (TABELA 7.2).

TABELA 7.2 - Análises granulométricas (\%) do solo segundo Departamento de Agricultura dos Estados Unidos e dos solo/sedimentos e sedimentos de fundo, segundo Sheppard (1954).

\begin{tabular}{|c|c|c|c|c|c|}
\hline \multicolumn{2}{|c|}{ Classificação } & \multirow{2}{*}{$\begin{array}{l}\text { ARGILA } \\
17,64\end{array}$} & \multirow{2}{*}{$\begin{array}{l}\text { SILTE } \\
20,70\end{array}$} & \multirow{2}{*}{$\begin{array}{l}\text { AREIA } \\
61,66\end{array}$} & \multirow{2}{*}{$\begin{array}{c}\text { Departamento de Agricultura } \\
\text { dos Estados Unidos }\end{array}$} \\
\hline \multirow{6}{*}{ A } & $S_{1(0-20)}$ & & & & \\
\hline & $\mathbf{S}_{1(20-50)}$ & 10,20 & 21,16 & 68,64 & Franco ArenosaAreia síltica \\
\hline & $S_{2(0-20)}$ & 32,13 & 33,55 & 34,32 & $\begin{array}{c}\text { Franco Argilosa Areia } \\
\text { síltica argilosa }\end{array}$ \\
\hline & $\mathrm{S}_{2(20-65)}$ & 29,47 & 11,49 & 59,04 & $\begin{array}{c}\text { Franco Argilo Arenosa } \\
\text { Areia argilosa }\end{array}$ \\
\hline & $S_{3(0-20)}$ & 17,03 & 18,15 & 64,82 & Franco ArenosaAreia síltica \\
\hline & $\mathrm{S}_{3}(20-40)$ & 23,46 & 15,51 & 61,03 & $\begin{array}{c}\text { Franco Argilo Arenosa } \\
\text { Areia argilosa }\end{array}$ \\
\hline \multicolumn{2}{|c|}{ Amostras } & ARGILA & SILTE & AREIA & $\begin{array}{c}\text { CLASSIFICAÇÃO SHEPPARD } \\
\text { (1954) }\end{array}$ \\
\hline \multirow{5}{*}{ B } & $\mathbf{R}_{\mathrm{S} 1}$ & 1,32 & 4,89 & 93,79 & Areia \\
\hline & $\mathbf{R}_{\mathrm{S} 2}$ & 13,15 & 26,32 & 60,53 & Areia síltica \\
\hline & $\mathbf{R}_{\mathrm{S3}}$ & 47,73 & 37,23 & 15,04 & Argila síltica \\
\hline & $\mathbf{R}_{\mathrm{S} 4}$ & 3,77 & 7,59 & 88,64 & Areia \\
\hline & $\mathbf{R}_{\mathrm{S} 5}$ & 43,24 & 17,24 & 39,52 & Argila arenosa \\
\hline C & $\mathrm{L}_{\mathrm{s} 1}$ & 43,24 & 17,24 & 39,52 & Argila Arenosa \\
\hline
\end{tabular}

(A) solo, (B) solo/sedimento e (C) sedimento de fundo. 
Segundo o Departamento de Agricultura dos Estados Unidos nos solos prevalecem as frações franco argilo arenosa e franco arenosa (FIGURA 7.1). e nas projeções em Diagrama de Sheppard, prevaleceram as frações arenosas para as amostras de solo/sedimento e argila arenosa para a amostra de sedimento de fundo (FIGURA 7.2 a e b, respectivamente).

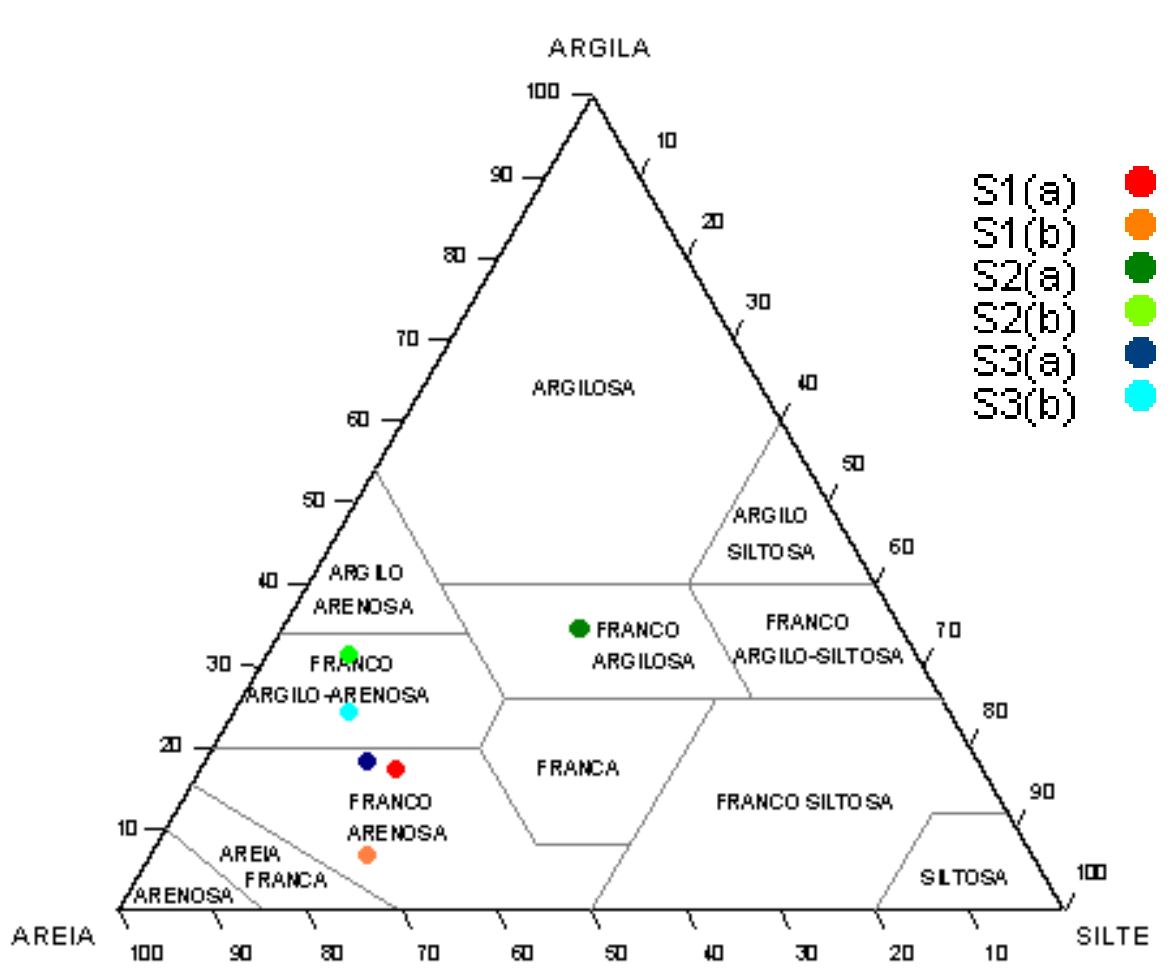

FIGURA 7.1 - Diagrama triangular do Departamento de Agricultura dos Estados Unidos para classificação de solos. 


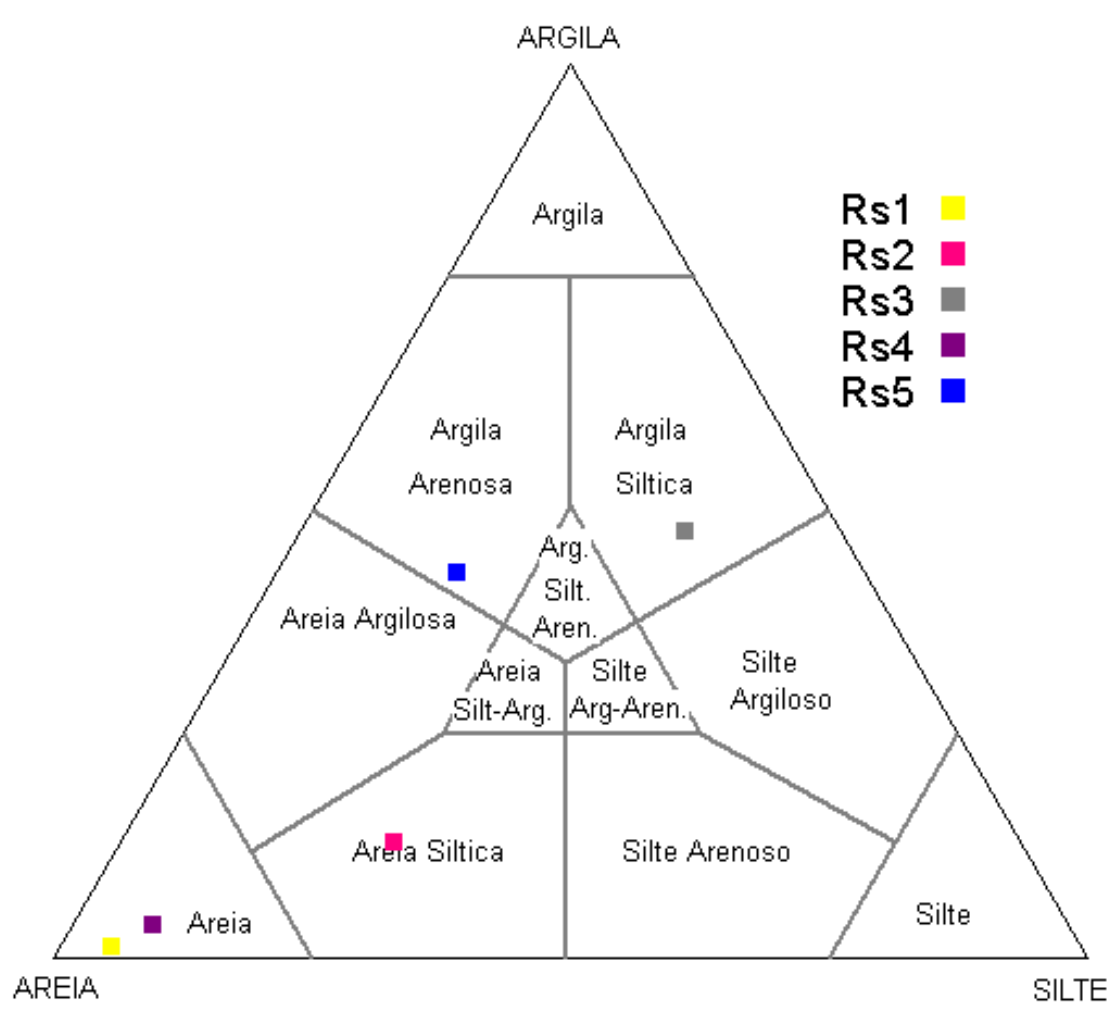

(a)

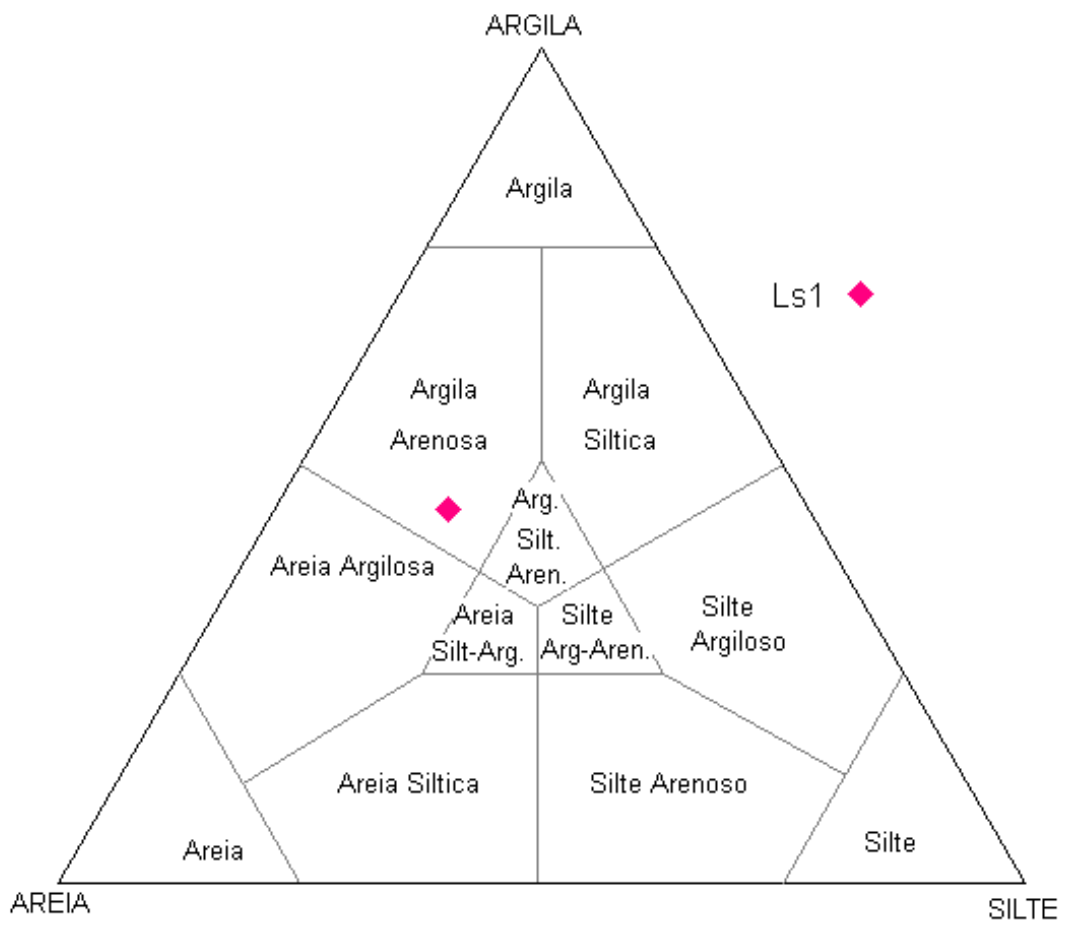

(b)

FIGURA 7.2 - Diagrama triangular de SHEPARD (1954). 


\subsection{ANÁLISE MINERALÓGICA}

Os materiais sólidos, depois de secos, destorroados e quarteados, foram moídos em moinho de anel e analisados por Difração de Raios $X$ nos Laboratórios de Difração de Raios X (D5000/SIEMENS) com raduação CuK $\alpha$ do IGc da USP.

Todas as amostras, tanto no solo, solo/sedimento e sedimento de fundo são constituídas essencialmente por caulinita, gibbsita e illita, (TABELA 7.3). Devido à homogeneidade mineralógica dos materiais analisados, são apresentados apenas dois difratogramas representando todas as amostras (FIGURA 7.3 a e b).

TABELA 7.3 - Resultados das análises mineralógicas do solo e sedimentos de fundo por Difração de Raio $X$

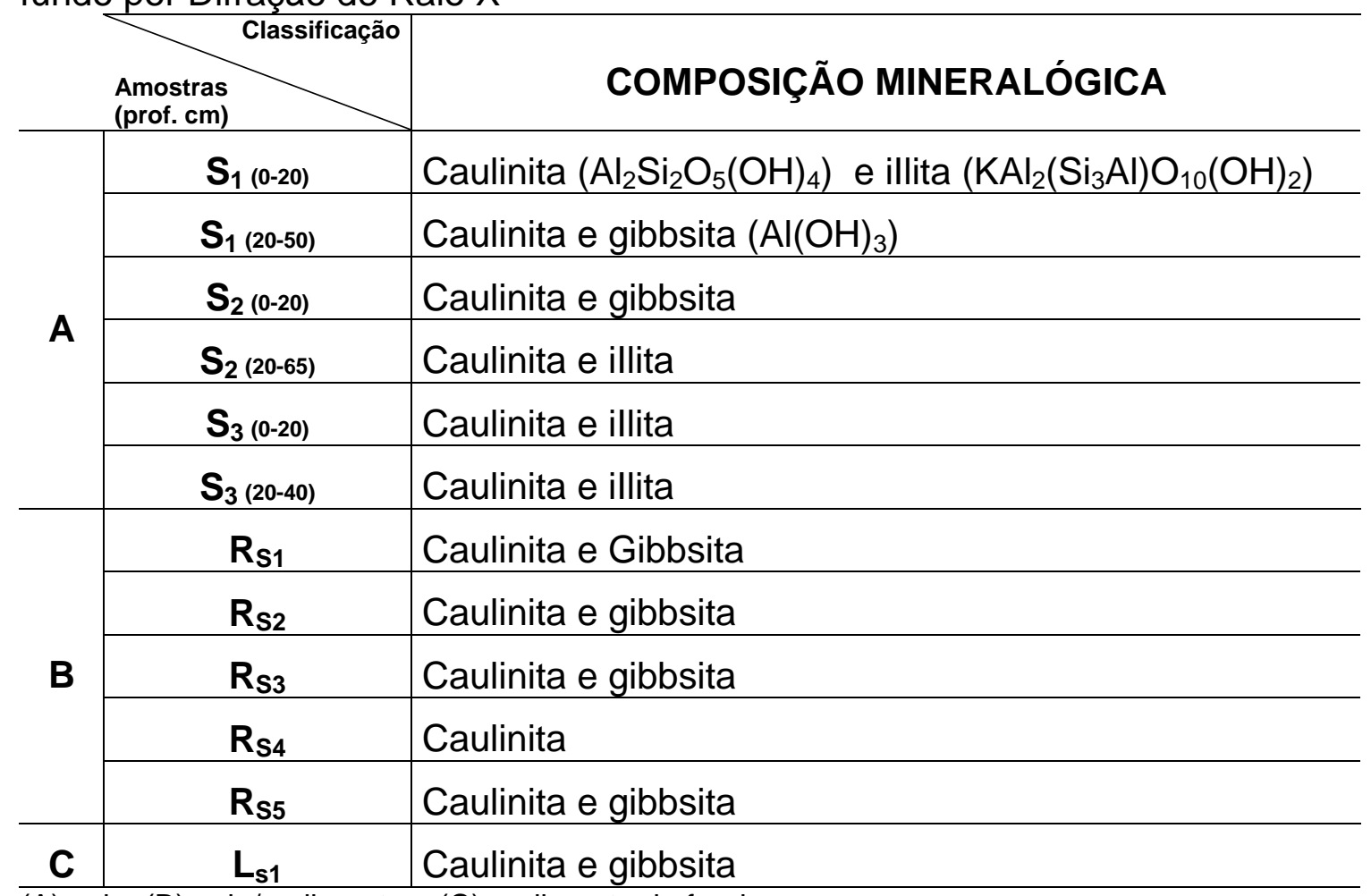

(A) solo, (B) solo/sedimento e (C) sedimento de fundo. 
(a) Difratograma representando as amostras de solo

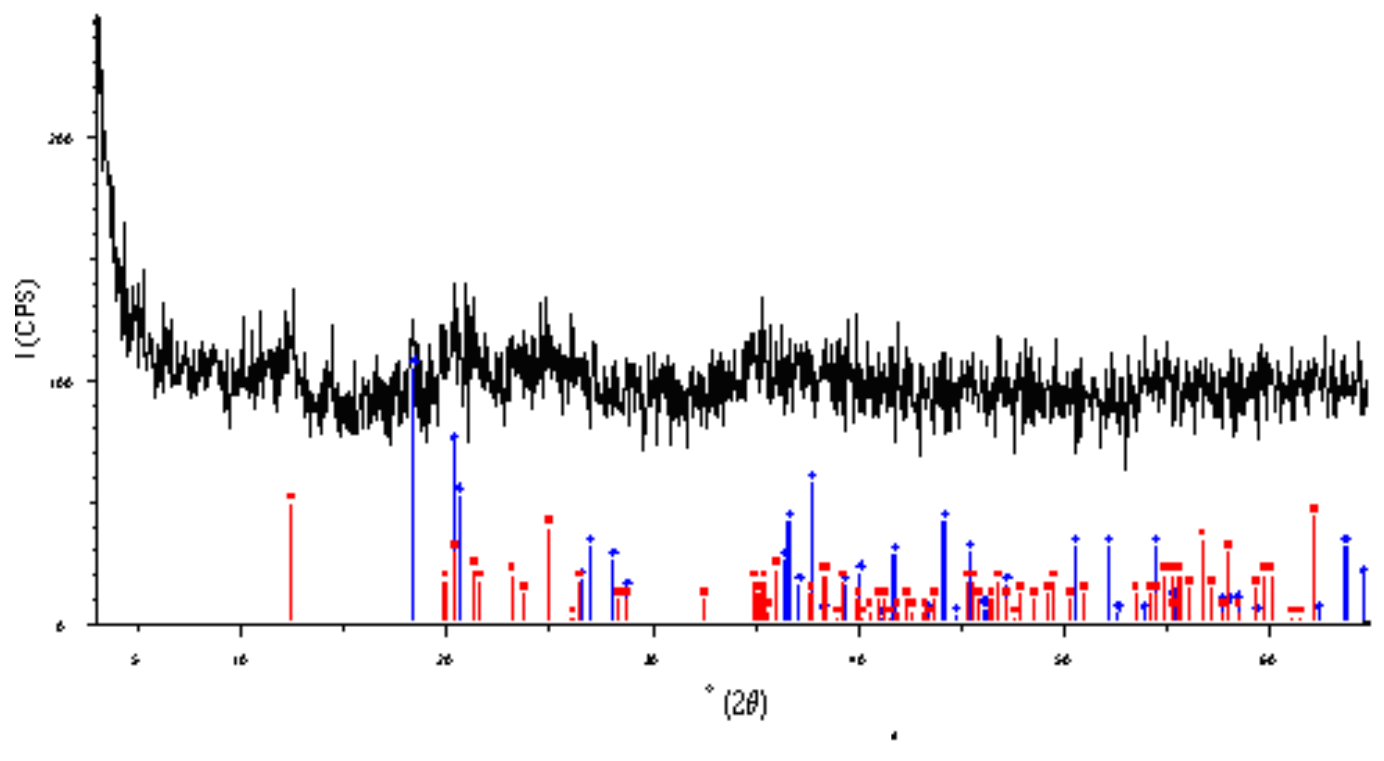

$\square$ caulinita 4 gibbsita

(b) Difratograma representando as amostras de solo/sedimento

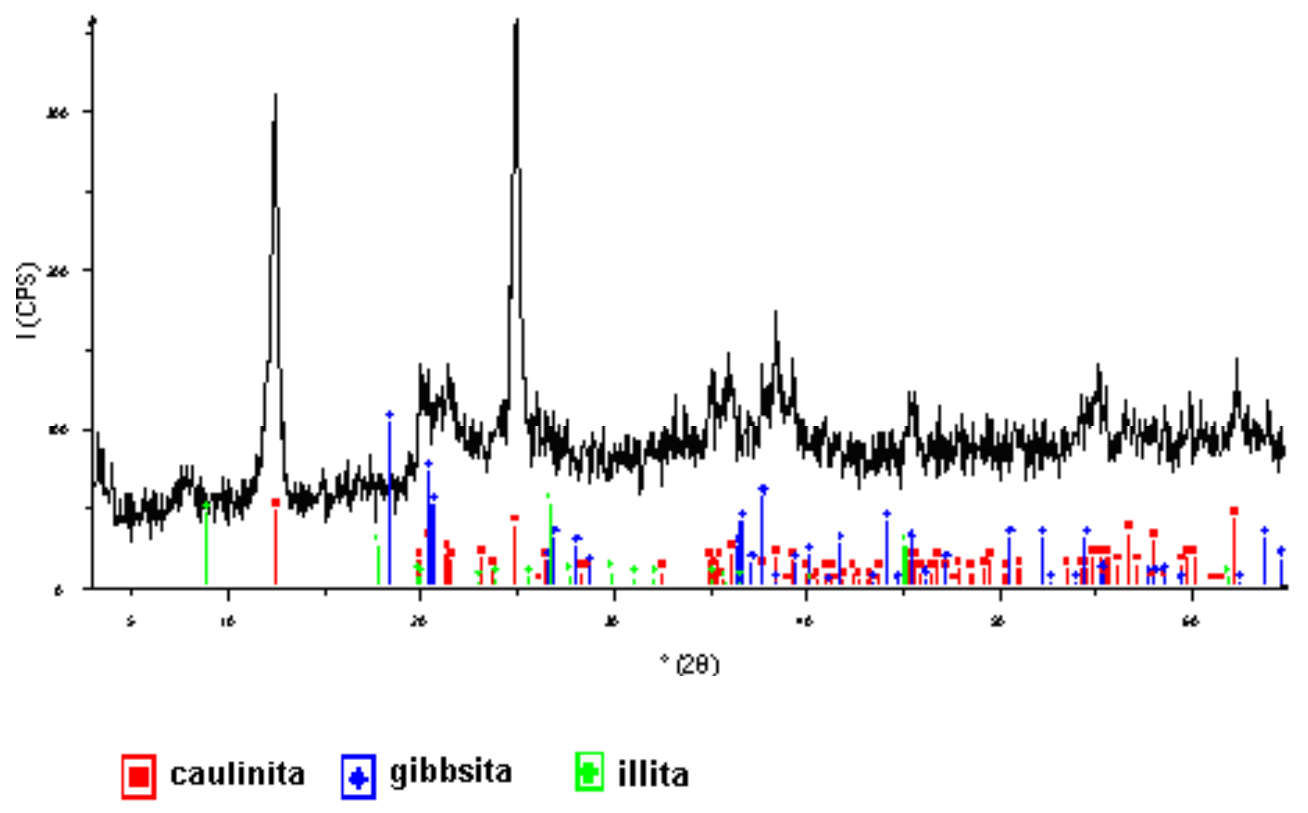

FIGURA 7.3 - Difratogramas das análises mineralógicas 


\subsection{FLUORESCÊNCIA DE RAIOS X}

O solo, solo/sedimento e sedimento de fundo foram analisados quimicamente através da Espectrofotometria por Fluorescência de Raios X, segundo procedimentos do Laboratório de Fluorescência de Raios X do IGc da USP. Os resultados encontram-se nas TABELAS 7.4 e 7.5.

TABELA 7.4 - Análises químicas dos constituintes maiores (\%) do solo, solo/sedimentos e sedimento de fundo, obtidas através da Espectrometria por Fluorescência de Raios $X$

\begin{tabular}{c|c|c|c|c|c|c|c|c|c|c|c}
\hline $\begin{array}{c}\text { Amostras } \\
\text { (Prof. cm) }\end{array}$ & $\begin{array}{c}\mathbf{S}_{1} \\
\mathbf{( 0 - 2 0 )}\end{array}$ & $\begin{array}{c}\mathbf{S}_{\mathbf{1}} \\
(\mathbf{2 0 - 5 0 )}\end{array}$ & $\begin{array}{c}\mathbf{S}_{2} \\
(\mathbf{0 - 2 0 )}\end{array}$ & $\begin{array}{c}\mathbf{S}_{\mathbf{2}} \\
\mathbf{( 2 0 - 6 5 )}\end{array}$ & $\begin{array}{c}\mathbf{S}_{\mathbf{3}} \\
\mathbf{( 0 - 2 0 )}\end{array}$ & $\begin{array}{c}\mathbf{S}_{\mathbf{3}} \\
(\mathbf{2 0 - 4 0 )}\end{array}$ & $\mathbf{R}_{\mathbf{S 2}}$ & $\mathbf{R}_{\mathbf{S 3}}$ & $\mathbf{R}_{\mathbf{S} 4}$ & $\mathbf{R}_{\mathbf{S 5}}$ & $\mathbf{L}_{\mathbf{s} 1}$ \\
\hline $\mathrm{SiO}_{2}$ & 68,32 & 76,05 & 63,48 & 62,94 & 72,86 & 70,81 & 73,75 & 46,39 & 85,06 & 62,77 & 84,97 \\
\hline $\mathrm{Al}_{2} \mathrm{O}_{3}$ & 17,13 & 12,35 & 18,20 & 19,49 & 12,09 & 14,72 & 11,23 & 26,82 & 7,17 & 18,47 & 7,16 \\
\hline $\mathrm{Fe}_{2} \mathrm{O}_{3}$ & 5,58 & 4,68 & 5,82 & 9,09 & 4,77 & 4,55 & 3,98 & 8,03 & 2,32 & 6,53 & 1,77 \\
\hline $\mathrm{MnO}$ & 0,03 & 0,03 & 0,06 & 0,06 & 0,08 & 0,06 & 0,05 & 0,07 & 0,04 & 0,02 & 0,03 \\
\hline $\mathrm{MgO}$ & 0,43 & 0,46 & 0,48 & 0,51 & 0,59 & 0,32 & 0,49 & 0,31 & 0,30 & 0,15 & 0,34 \\
\hline $\mathrm{CaO}$ & nd & nd & 0,98 & 0,36 & 0,60 & 0,48 & 0,86 & 0,10 & 0,18 & nd & 0,18 \\
\hline $\mathrm{Na}_{2} \mathrm{O}$ & nd & nd & 0,61 & 0,12 & 0,43 & 0,23 & 0,67 & 0,03 & 0,21 & nd & 0,22 \\
\hline $\mathrm{K}_{2} \mathrm{O}$ & 1,21 & 1,11 & 2,01 & 1,83 & 1,95 & 1,40 & 2,07 & 1,38 & 1,98 & 0,64 & 2,96 \\
\hline $\mathrm{TIO}_{2}$ & 0,76 & 0,53 & 0,82 & 0,70 & 0,58 & 0,56 & 0,46 & 0,84 & 0,24 & 0,91 & 0,31 \\
\hline $\mathrm{P}_{2} \mathrm{O}_{5}$ & 0,05 & 0,37 & 0,17 & 0,07 & 0,11 & 0,08 & 0,11 & 0,10 & 0,03 & 0,10 & 0,04 \\
\hline
\end{tabular}

nd = não detectado

TABELA 7.5 - Análises químicas dos elementos-traço $\left(\mathrm{mg} \mathrm{kg}^{-1}\right)$ do solo, solo/sedimento e sedimento de fundo, obtidas através da Espectrometria por Fluorescência de Raios X

\begin{tabular}{|c|c|c|c|c|c|c|c|c|c|c|c|}
\hline $\begin{array}{r}\text { Amostras } \\
\text { (Prof. } \mathrm{cm} \text { ) }\end{array}$ & $\begin{array}{c}S_{1} \\
(0-20)\end{array}$ & $\begin{array}{c}\mathrm{S}_{1} \\
(20-50)\end{array}$ & $\begin{array}{c}S_{2} \\
(0-20)\end{array}$ & $\begin{array}{c}S_{2} \\
(20-65)\end{array}$ & $\begin{array}{c}\mathrm{S}_{3} \\
(0-20)\end{array}$ & $\begin{array}{c}\mathrm{S}_{3} \\
(20-40)\end{array}$ & $\mathbf{R}_{\mathbf{S} 2}$ & $\mathbf{R}_{\mathrm{S} 3}$ & $\mathbf{R}_{\mathbf{S} 4}$ & $\mathbf{R}_{\mathbf{S 5}}$ & $\mathrm{L}_{\mathrm{s} 1}$ \\
\hline $\mathrm{Cr}_{\text {total }}$ & 57 & 53 & 76 & 66 & 74 & 18 & 65 & 13 & 14 & 73 & 19 \\
\hline $\mathrm{Cu}^{2+}$ & 63 & 32 & 130 & 33 & 65 & 68 & 39 & 80 & 28 & 18 & 7 \\
\hline $\mathrm{Pb}^{2+}$ & 42 & 37 & 44 & 48 & 92 & 40 & 227 & 44 & 43 & 28 & 23 \\
\hline $\mathrm{Ni}^{2+}$ & 21 & 25 & 80 & 22 & 30 & 16 & 23 & 38 & 16 & 22 & 6 \\
\hline $\mathrm{Zn}^{2+}$ & 74 & 53 & 95 & 69 & 146 & 48 & 123 & 81 & 41 & 26 & 18 \\
\hline
\end{tabular}




\subsection{EXTRAÇÕES QUÍMICAS}

Objetivando detectar a disponibilidade iônica do solo, solo/sedimento e sedimento de fundo, foram efetuadas extrações nítricas (8M) cujos resultados encontram-se na TABELA 7.6.

TABELA 7.6 - Resultados obtidos nas extrações $\left(\mathrm{mg} \mathrm{kg}^{-1}\right)$ de solo, solo/sedimento e sedimento de fundo

\begin{tabular}{|c|c|c|c|c|c|c|c|c|c|c|c|c|}
\hline $\begin{array}{l}\text { Amostras } \\
\text { (Prof. cm) }\end{array}$ & $\begin{array}{c}\mathrm{S}_{1} \\
(0-20)\end{array}$ & $\begin{array}{c}\mathrm{S}_{1} \\
(20-50)\end{array}$ & $\begin{array}{c}\mathrm{S}_{2} \\
(0-20)\end{array}$ & $\begin{array}{c}\mathrm{S}_{2} \\
(20-65)\end{array}$ & $\begin{array}{c}\mathrm{S}_{3} \\
(0-20)\end{array}$ & $\begin{array}{c}\mathrm{S}_{3} \\
(20-40)\end{array}$ & $\mathbf{R}_{\mathrm{S} 1}$ & $\mathbf{R}_{\mathrm{S} 2}$ & $\mathbf{R}_{\mathrm{S3}}$ & $\mathbf{R}_{\text {s4 }}$ & $\mathbf{R}_{\mathrm{S5}}$ & $L_{s 1}$ \\
\hline $\mathrm{Al}^{3+}$ & 2325,74 & 2359,92 & 3333,99 & 2899,53 & 2335,29 & 2289,85 & 2499,27 & 2992,32 & 3625,40 & 896,94 & 1121,31 & 3826,26 \\
\hline $\mathrm{Fe}_{\text {total }}$ & 691,03 & 610,17 & 3390,72 & 2696,34 & 2580,48 & 1508,24 & 16412,39 & 5230,83 & 12406,40 & 1073,16 & 1778,64 & 4226,06 \\
\hline $\mathrm{Mn}^{2+}$ & 16,97 & 19,94 & 120,42 & 89,78 & 147,51 & 97,95 & 956,17 & 111,67 & 261,78 & 67,32 & 41,56 & 35,54 \\
\hline $\mathrm{Ca}^{2+}$ & 48,93 & 149,55 & 1939,69 & 966,82 & 1236,92 & 834,58 & 2099,89 & 1332,13 & 429,71 & 413,82 & 127,59 & 112,54 \\
\hline $\mathrm{Ni}^{2+}$ & 1,99 & 2,99 & 4,97 & 4,72 & 5,98 & 2,99 & 5,83 & 6,98 & 3,95 & 4,95 & 4,83 & 2,96 \\
\hline $\mathrm{Pb}^{2+}$ & 32,95 & 30,90 & 27,86 & 33,08 & 69,77 & 35,98 & 42,75 & 142,58 & 42,48 & 31,68 & 22,23 & 22,65 \\
\hline $\mathrm{Cu}^{2+}$ & 33,95 & 6,98 & 8,95 & 9,45 & 32,89 & 44,97 & 19,43 & 23,93 & 14,82 & 8,91 & 3,86 & 6,91 \\
\hline $\mathrm{Cd}^{2+}$ & 1,99 & 0,99 & 1,99 & 1,89 & 1,99 & 1,99 & 3,88 & 1,99 & 1,97 & 1,98 & 1,93 & 1,97 \\
\hline $\mathrm{Cr}_{\text {total }}$ & 0,99 & nd & 1,99 & 3,78 & 8,97 & 2,99 & 6,80 & 5,98 & 6,91 & 1,98 & 1,93 & 4,93 \\
\hline $\mathrm{Zn}^{2+}$ & 24,96 & 11,96 & 17,91 & 13,23 & 62,79 & 17,99 & 31,09 & 60,82 & 22,72 & 14,85 & 8,69 & 7,89 \\
\hline
\end{tabular}

Os resultados obtidos nas extrações totais, quando comparados aos resultados das análises químicas (FRX e extrações totais), mostram baixa disponibilidade iônica para as espécies químicas, com exceção do chumbo onde pôde-se perceber que, em praticamente todas as amostras, as disponibilidade deste íons está associada à origens antrópicas, ou seja, associada à parte sólida do solo e não estrutural. 


\subsection{ANÁLISES QUÍMICAS DAS ÁGUAS}

As amostras de águas coletadas e acidificadas foram analisadas quimicamente por Espectrofotometria de Absorção Atômica de Chama (AAC), Modelo CGAA 7000 BC, realizadas no Laboratório do Centro de Pesquisa de águas Subterrâneas (CEPAS) do Instituto de Geociências da Universidade de São Paulo.

As análises químicas de ânions foram analisadas por Cromatografia Líquida (Dionex 2010 i), realizadas também no laboratório do CEPAS.

Os resultados das análises químicas para os cátions das águas subterrâneas são apresentados nas TABELAS 7.7.

TABELA 7.7 - Análises químicas de cátions $\left(\mathrm{mg} \mathrm{dm}^{-3}\right)$ das águas subterrâneas presentes na área dos Aterros

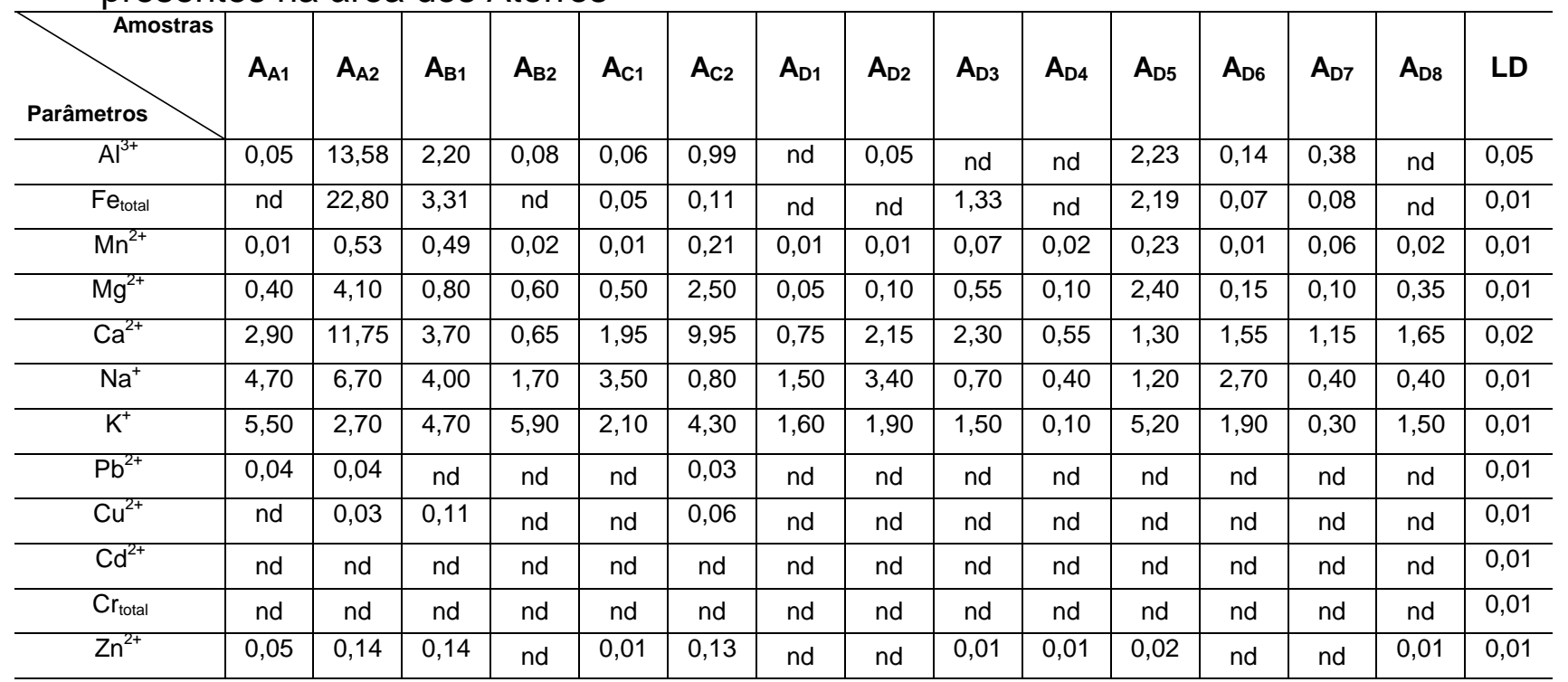

nd = não detectado

\begin{tabular}{|c|c|c|c|c|c|c|c|c|}
\hline & $\mathrm{Fe}_{\text {total }}$ & $\mathrm{Mn}^{2+}$ & $\mathrm{Al}^{3+}$ & $\mathrm{Pb}^{2+}$ & $\mathrm{Cu}^{2+}$ & $\mathrm{Zn}^{2+}$ & $\mathrm{Cd}^{2+}$ & $\mathrm{Cr}_{\text {total }}$ \\
\hline PORTARIA 396 & 0,30 & 0,10 & 0,20 & 0,01 & 2,00 & 5,00 & 0,05 & 0,05 \\
\hline PORTARIA 518 & 0,30 & 0,10 & 0,20 & 0,01 & 2,00 & 5,00 & 0,005 & 0,05 \\
\hline
\end{tabular}

1: Valores orientadores para águas subterrâneas da Resolução 396/08 do CONAMA (mg dm ${ }^{-3}$ )

2: Valores orientadores da Portaria 518/04 - Ministério da saúde - Padrão de potabilidade $\left(\mathrm{mg} \mathrm{dm}^{-3}\right)$ 
Os resultados analíticos das águas subterrâneas, em diversos pontos, indicam que o ferro, manganês e alumínio encontram-se em concentrações acima dos permitidos pelos órgãos oficiais. O ferro superou em muito os valores máximos permitidos pela CETESB, em especial nos pontos $\mathbf{A}_{\mathrm{A} 2}$ que ultrapassou quase 100 vezes o indicado para que a água pudesse ser consumida e $A_{B 1}, A_{D 3}$ e $A_{D 5}$ que também ultrapassaram os valores máximos permitidos.

Mais preocupante, contudo, dada sua periculosidade, foram os resultados obtidos para o chumbo que apresentaram, nas estações de amostragem $A_{A 1}, A_{A 2}$ e $A_{C 2}$, concentrações até quatro vezes superiores aos limites máximos permitidos. Este fato se reveste de grande preocupação, uma vez que na região a grande maioria da população utiliza para consumo águas extraídas de poços do tipo cacimba.

Valores de $\mathrm{pH}$ baixos propiciaram a disponibilidade do alumínio, ferro e chumbo na água subterrânea.

Utilizando o diagrama de concentração em relação ao pH (MORGAN \& STUMM, 1995) observa-se que o chumbo na faixa de $\mathrm{pH}$ que se encontra indica equilíbrio entre $\mathrm{Pb}^{2+} / \mathrm{PbCO}_{3}$, no entanto com grande domínio da forma iônica $\mathrm{Pb}^{2+}$, além de coexistirem quantidades negligenciáveis de $\mathrm{Pb}\left(\mathrm{SO}_{4}\right)_{2}, \mathrm{PbCl}^{+}, \mathrm{PbOH}^{+}$.

O alumínio aparece na forma iônica $\mathrm{Al}^{3+}$ quando plotados seus valores no diagramas de concentrações em função do pH (MORGAN \& STUMM, 1995), além de concentrações ínfimas de $\mathrm{Al}(\mathrm{OH})_{2}^{+}, \mathrm{AlOH}^{2+}$ e $\mathrm{Al}(\mathrm{OH})_{4}^{-}$e $\mathrm{Al}(\mathrm{OH})_{3(a q)}$.

A projeção dos valores de $\mathrm{pH}$ em função do potencial de óxidoredução (Eh) (FIGURA 7.4. a, b e c), mostram equilíbrio dos íons ferro com suas forma insolúvel de óxido/hidróxido. Os íons manganês mostram sua estabilidade na forma iônica reduzida como $\mathrm{Mn}^{2+}$. 
MOURA, C.L. (2008). ÍONS METÁLICOS (Al, Fe, Mn e Pb) ASSOCIADOS A ATERROS (SANITÁRIO E INDUSTRIAL) NO MUNICÍPIO DE TREMEMBÉ/SP.

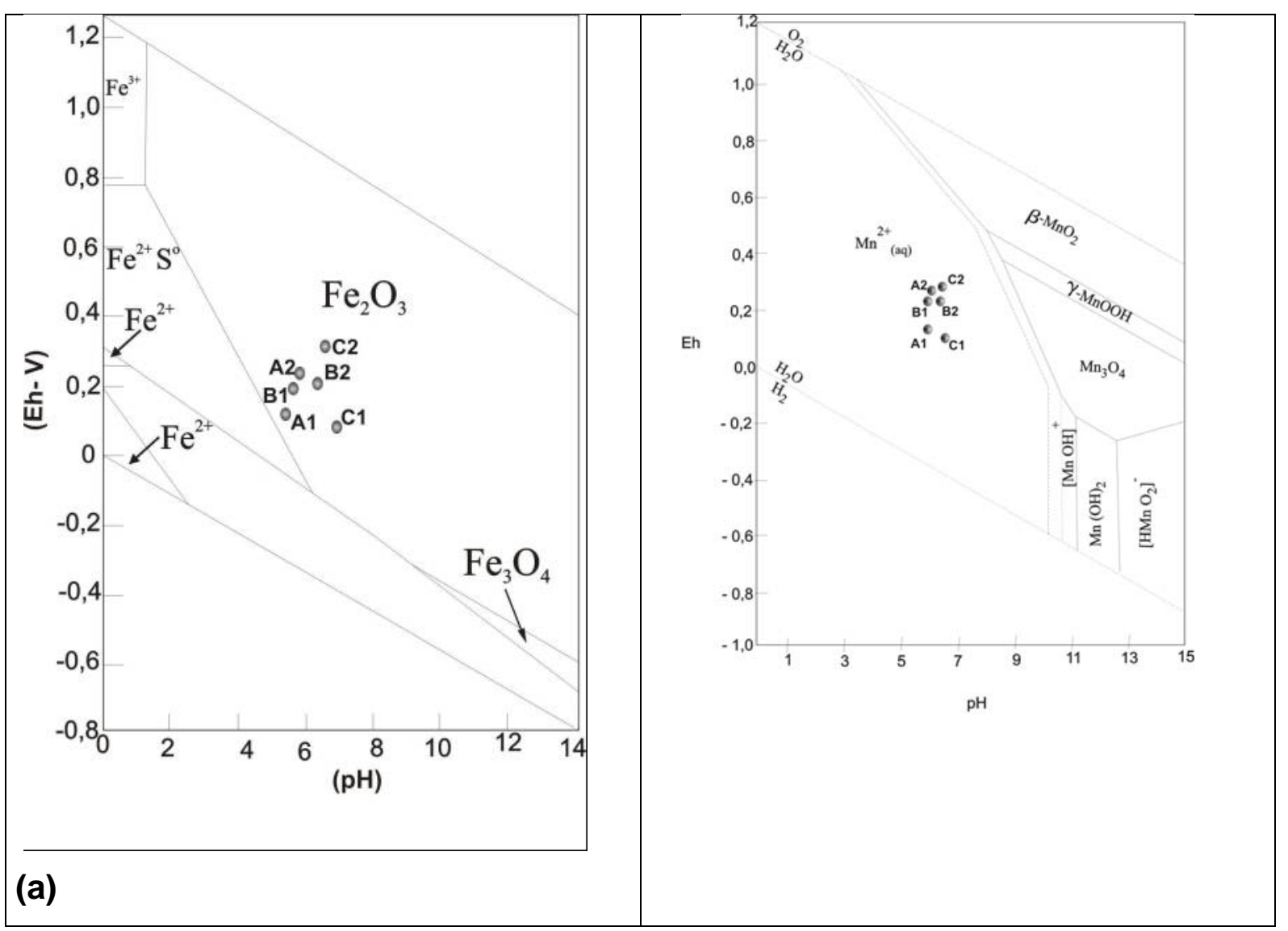


MOURA, C.L. (2008). ÍONS METÁLICOS (Al, Fe, Mn e Pb) ASSOCIADOS A ATERROS (SANITÁRIO E INDUSTRIAL) NO MUNICíPIO DE TREMEMBÉ/SP.

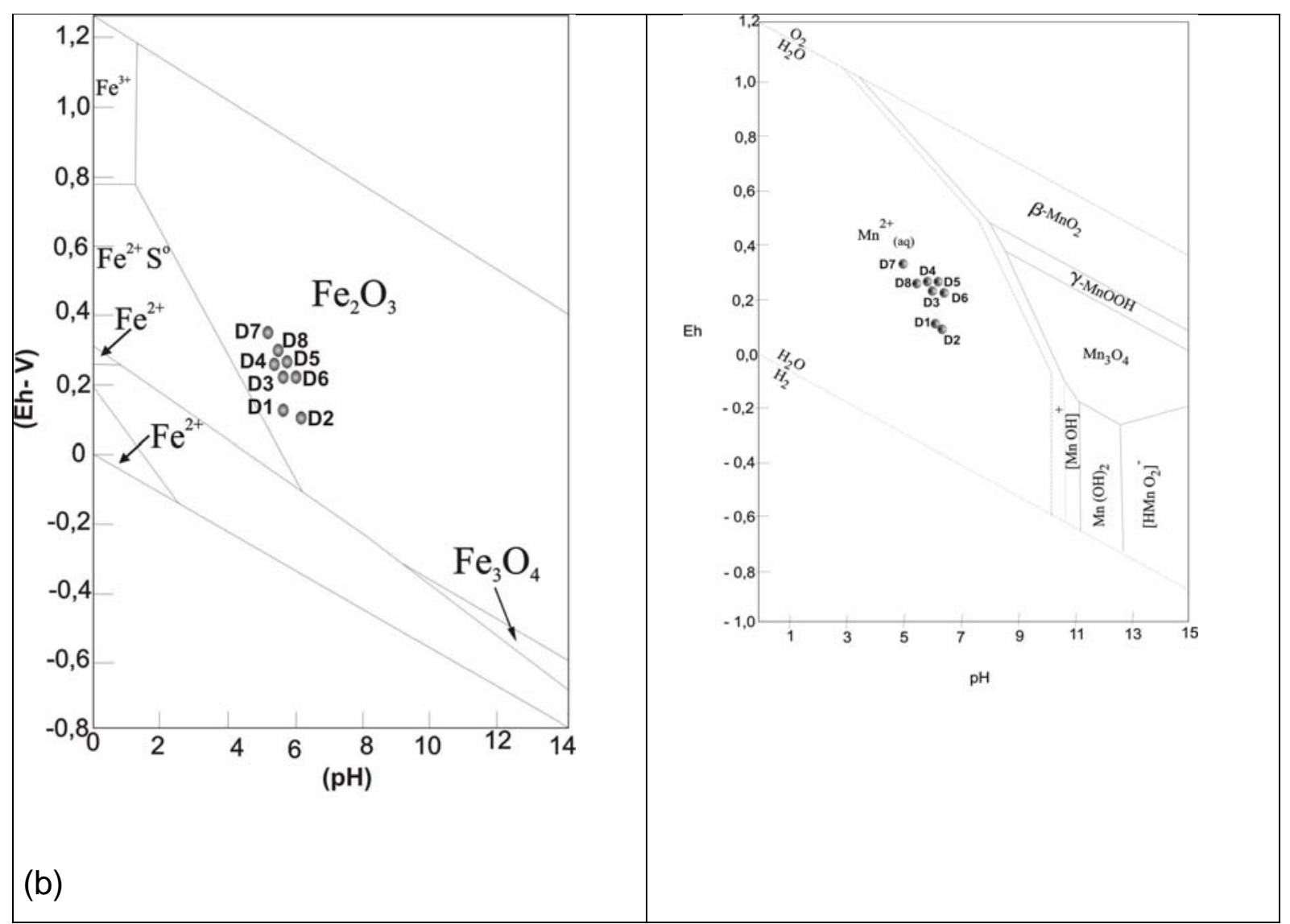




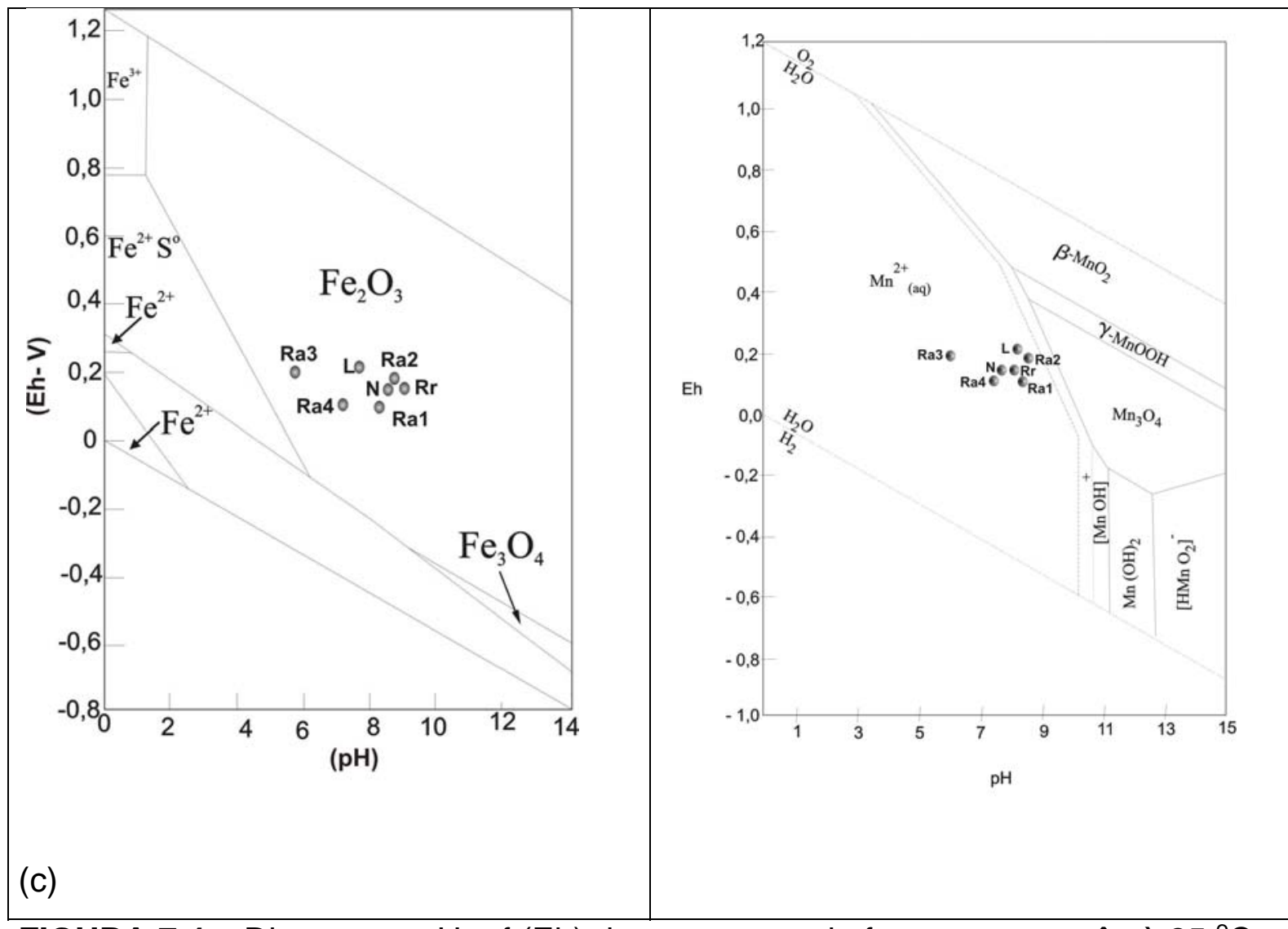

FIGURA 7.4 - Diagramas $\mathrm{pH}=\mathrm{f}(\mathrm{Eh})$ de compostos de ferro e manganês à $25^{\circ} \mathrm{C} e$ 1 atm. Águas subterrâneas dos Aterros A, B e C (a), Aterro D (b) e águas Superficiais (c). Modificado de Brookins (1988) e Hypolito (1980). 
As elevadas concentrações dos íons chumbo, ferro, alumínio e manganês que superam os valores máximos permitidos, na maioria dos casos aparecem associados aos aterros sanitários.

Os resultados das análises químicas para os cátions das águas superficiais são apresentados na TABELA 7.8.

TABELA 7.8 - Resultados das análises químicas de cátions $\left(\mathrm{mg} \mathrm{dm}^{-3}\right)$ das águas superficiais presentes na área dos Aterros e entorno

\begin{tabular}{c|c|c|c|c|c|c|c|c|c}
\hline Amostras & $\mathbf{R}_{\mathbf{r}}$ & $\mathbf{N}$ & $\mathbf{L}$ & $\mathbf{R}_{\mathbf{L}}$ & $\mathbf{R}_{\mathbf{a} \mathbf{}}$ & $\mathbf{R}_{\mathbf{a} 2}$ & $\mathbf{R}_{\mathbf{a} 3}$ & $\mathbf{R}_{\mathbf{a} 4}$ & $\mathbf{L D}$ \\
\hline $\mathrm{Al}^{3+}$ & & & & & & & & & \\
\hline $\mathrm{Fe}_{\text {total }}$ & 0,05 & 0,93 & 0,29 & 0,30 & 1,06 & 4,54 & 0,89 & 0,55 & 0,01 \\
\hline $\mathrm{Mn}^{2+}$ & 0,02 & 0,15 & 0,01 & 0,01 & 0,04 & 0,52 & 0,13 & 0,19 & 0,01 \\
\hline $\mathrm{Mg}^{2+}$ & 0,45 & 0,40 & 0,35 & 0,35 & 0,55 & 0,45 & 1,50 & 1,95 & 0,01 \\
\hline $\mathrm{Ca}^{2+}$ & 1,30 & 0,95 & 0,55 & 0,55 & 1,35 & 3,20 & 1,45 & 8,60 & 0,02 \\
\hline $\mathrm{Na}^{+}$ & 2,20 & 2,30 & 2,30 & 2,30 & 2,40 & 28,60 & 2,30 & 32,60 & 0,01 \\
\hline $\mathrm{K}^{+}$ & 2,00 & 1,60 & 1,10 & 1,10 & 1,80 & 3,80 & 1,30 & 3,60 & 0,01 \\
\hline $\mathrm{Pb}^{2+}$ & $\mathrm{nd}$ & $\mathrm{nd}$ & $\mathrm{nd}$ & $\mathrm{nd}$ & $\mathrm{nd}$ & $\mathrm{nd}$ & $\mathrm{nd}$ & $\mathrm{nd}$ & 0,01 \\
\hline $\mathrm{Cu}^{2+}$ & $\mathrm{nd}$ & $\mathrm{nd}$ & $\mathrm{nd}$ & $\mathrm{nd}$ & $\mathrm{nd}$ & $\mathrm{nd}$ & $\mathrm{nd}$ & $\mathrm{nd}$ & 0,01 \\
\hline $\mathrm{Cr}_{\text {total }}$ & $\mathrm{nd}$ & $\mathrm{nd}$ & $\mathrm{nd}$ & $\mathrm{nd}$ & $\mathrm{nd}$ & $\mathrm{nd}$ & $\mathrm{nd}$ & $\mathrm{nd}$ & 0,01 \\
\hline $\mathrm{Cd}^{2+}$ & $\mathrm{nd}$ & $\mathrm{nd}$ & $\mathrm{nd}$ & $\mathrm{nd}$ & $\mathrm{nd}$ & $\mathrm{nd}$ & $\mathrm{nd}$ & $\mathrm{nd}$ & 0,01 \\
\hline $\mathrm{Zn}^{2+}$ & $\mathrm{nd}$ & 0,01 & $\mathrm{nd}$ & $\mathrm{nd}$ & $\mathrm{nd}$ & $\mathrm{nd}$ & 0,01 & 0,03 & 0,01 \\
\hline $\mathrm{nd}=\mathrm{não}^{2+}$ detectado & & & & & & & &
\end{tabular}

\begin{tabular}{|c|c|c|c|c|c|c|c|c|}
\hline & $\mathrm{Fe}_{\text {total }}$ & $\mathrm{Mn}^{2+}$ & $\mathrm{Al}^{3+}$ & $\mathrm{Pb}^{2+}$ & $\mathrm{Cu}^{2+}$ & $\mathrm{Zn}^{2+}$ & $\mathrm{Cd}^{2+}$ & $\mathrm{Cr}_{\text {total }}$ \\
\hline RESOLUÇÃO 357 & 0,30 & 0,10 & 0,10 & 0,01 & 0,01 & 0,18 & 0,001 & 0,05 \\
\hline PORTARIA 518 & 0,30 & 0,10 & 0,20 & 0,01 & 2,00 & 5,00 & 0,005 & 0,05 \\
\hline
\end{tabular}

1: Valores orientadores da Resolução $357 / 05$ - água superficial, classe II ( $\mathrm{mg} \mathrm{dm}^{-3}$ )

2: Valores orientadores da Portaria 518/04 - Ministério da saúde - Padrão de potabilidade ( $\left.\mathrm{mg} \mathrm{dm}^{-3}\right)$

Da mesma forma que as águas subterrâneas, as superficiais, em alguns casos, em especial aquelas com influência dos Aterros, ultrapassam os limites máximos permitidos para ferro, manganês e alumínio.

Dados analíticos dos ânions das águas subterrâneas e superficiais enviadas para análises químicas no Espectrofotômetro de Absorção Atômica encontram-se nas TABELAS 7.9 e 7.10, respectivamente. 
TABELA 7.9 - Resultados dos ânions $\left(\mathrm{mg} \mathrm{dm}^{-3}\right)$ das análises químicas das águas subterrâneas presentes na área dos Aterros

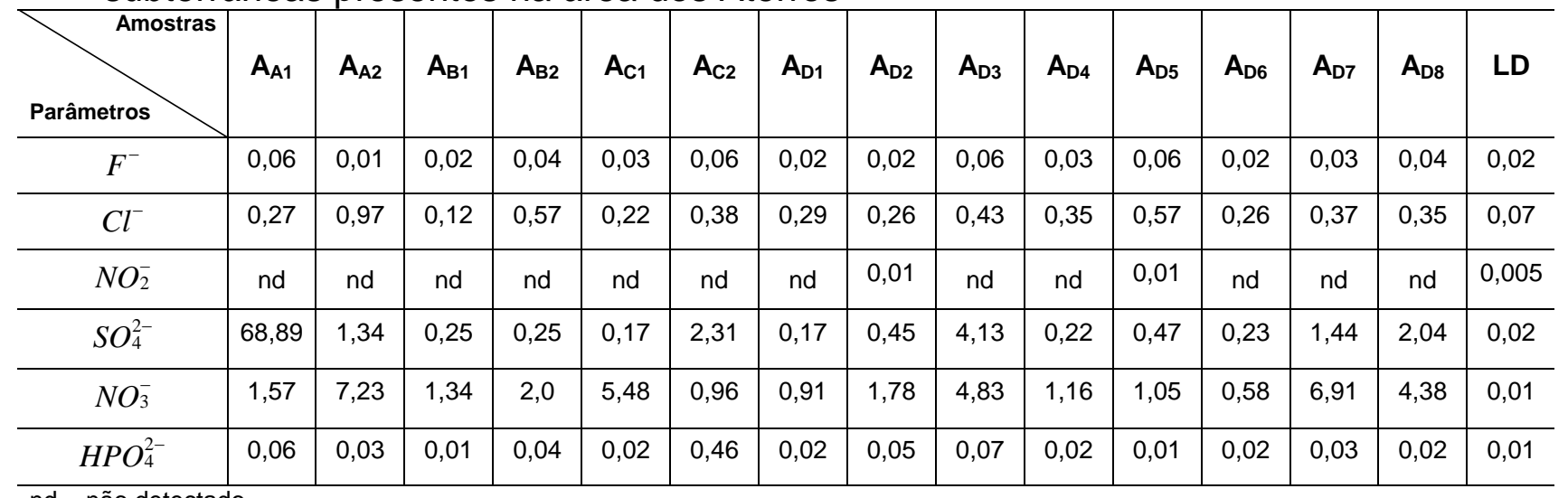

nd = não detectado

\begin{tabular}{|c|c|c|c|c|c|}
\hline & $\mathrm{F}^{-}$ & $\mathrm{Cl}^{-}$ & $\mathrm{NO}_{3}^{-}$ & $\mathrm{NO}_{2}^{-}$ & $\mathrm{SO}_{4}^{2-}$ \\
\hline PORTARIA 396 & 1,5 & 250 & 10 & 1 & 250 \\
\hline
\end{tabular}

1: Valores orientadores para águas subterrâneas da Resolução 396/08 do CONAMA (mg dm"3)

TABELA 7.10 - Resultados dos ânions $\left(\mathrm{mg} \mathrm{dm}^{-3}\right)$ das análises químicas das águas superficiais presentes na área dos Aterros e entorno

\begin{tabular}{c|c|c|c|c|c|c|c|c}
\hline $\begin{array}{c}\text { Estações de } \\
\text { amostragem }\end{array}$ & $\mathbf{R}_{\mathbf{r}}$ & $\mathbf{N}$ & $\mathbf{L}$ & $\mathbf{R}_{\mathbf{a} 1}$ & $\mathbf{R}_{\mathbf{a} 2}$ & $\mathbf{R}_{\mathbf{a} 3}$ & $\mathbf{R}_{\mathbf{a} 4}$ & $\mathbf{L D}$ \\
\hline$F^{-}$ & 0,04 & 0,03 & 0,04 & 0,14 & 0,11 & 0,03 & 0,39 & 0,02 \\
\hline $\mathrm{Cl}^{-}$ & 0,65 & 0,96 & 1,14 & 1,38 & 24,91 & 0,96 & 23,36 & 0,07 \\
\hline $\mathrm{NO}_{2}^{-}$ & $\mathrm{nd}$ & $\mathrm{nd}$ & $\mathrm{nd}$ & $\mathrm{nd}$ & $\mathrm{nd}$ & $\mathrm{nd}$ & $\mathrm{nd}$ \\
\hline $\mathrm{SO}_{4}^{2-}$ & 1,06 & 2,31 & 0,84 & 1,45 & 30,24 & 0,36 & 126,06 & 0,02 \\
\hline $\mathrm{NO}_{3}^{-}$ & 3,16 & 0,72 & 1,02 & 2,36 & 1,77 & 0,87 & 1,68 & 0,01 \\
\hline $\mathrm{HPO}_{4}^{2-}$ & $\mathrm{ND}$ & 0,06 & 0,02 & 0,02 & 0,01 & 0,05 & 0,02 & 0,01 \\
\hline $\mathrm{nado}$
\end{tabular}

nd = não detectado

A presença de concentrações elevadas de sódio, potássio, sulfatos e cloretos foram responsáveis pelos valores elevados de condutividade elétrica para as amostras $\mathbf{R}_{\mathbf{a} 2}$ e $\mathbf{R}_{\mathbf{a} 4}$, ambas com influência direta dos Aterros. Esses íons foram também detectados, em grande quantidade, posteriormente quando se realizaram análises dos chorumes. 
Na FIGURA 7.5 é apresentado um fluxograma das etapas realizadas no campo e laboratório.

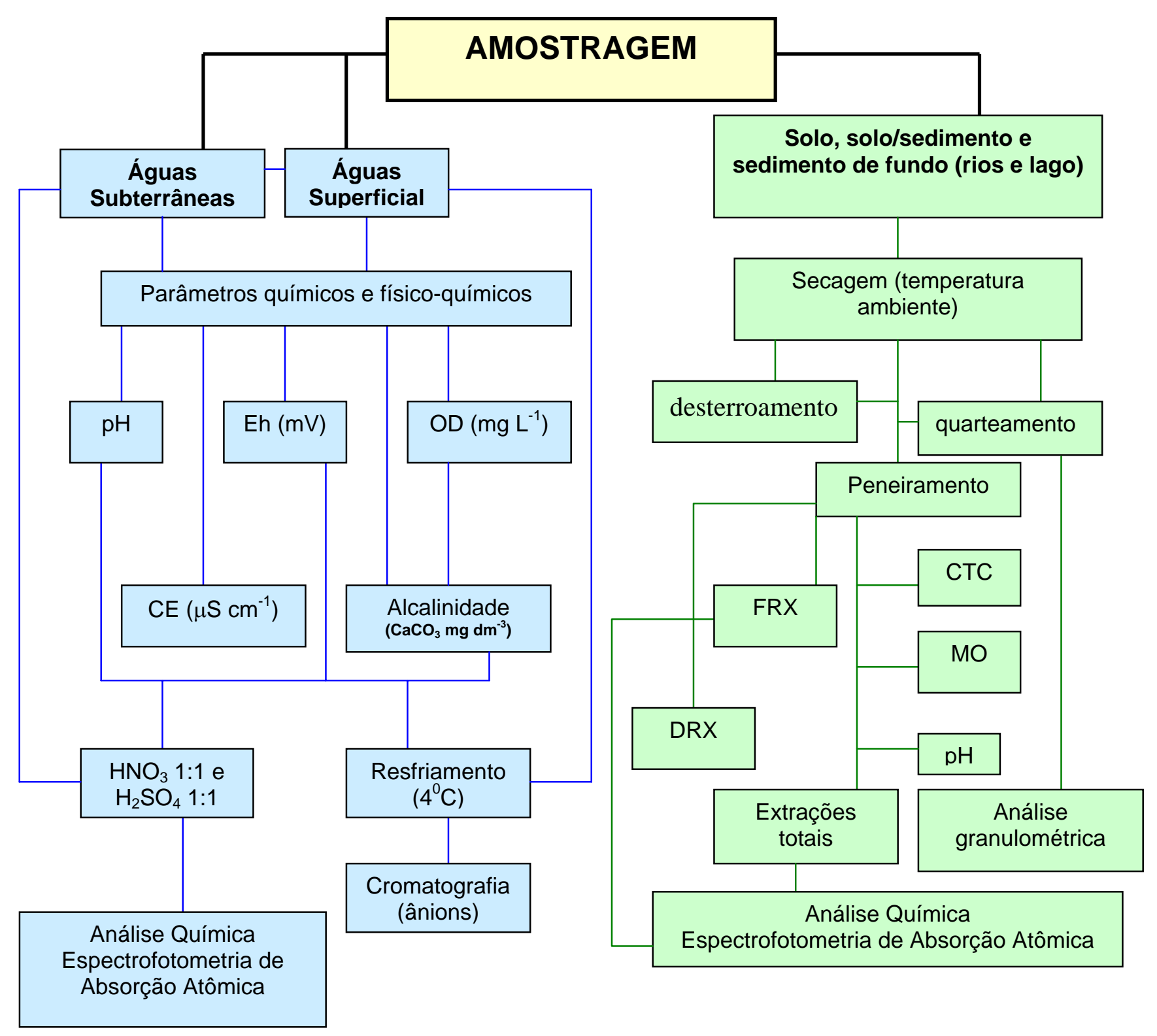

FIGURA 7.5 - Fluxograma das atividades de campo e laboratoriais. 


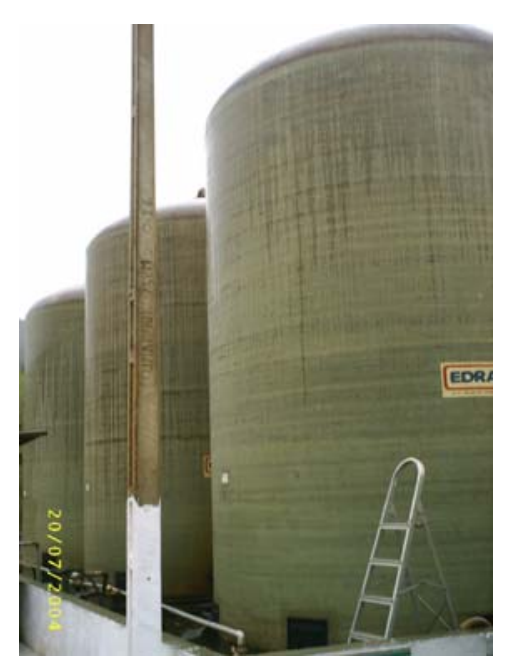

\section{CAPÍTULO III}
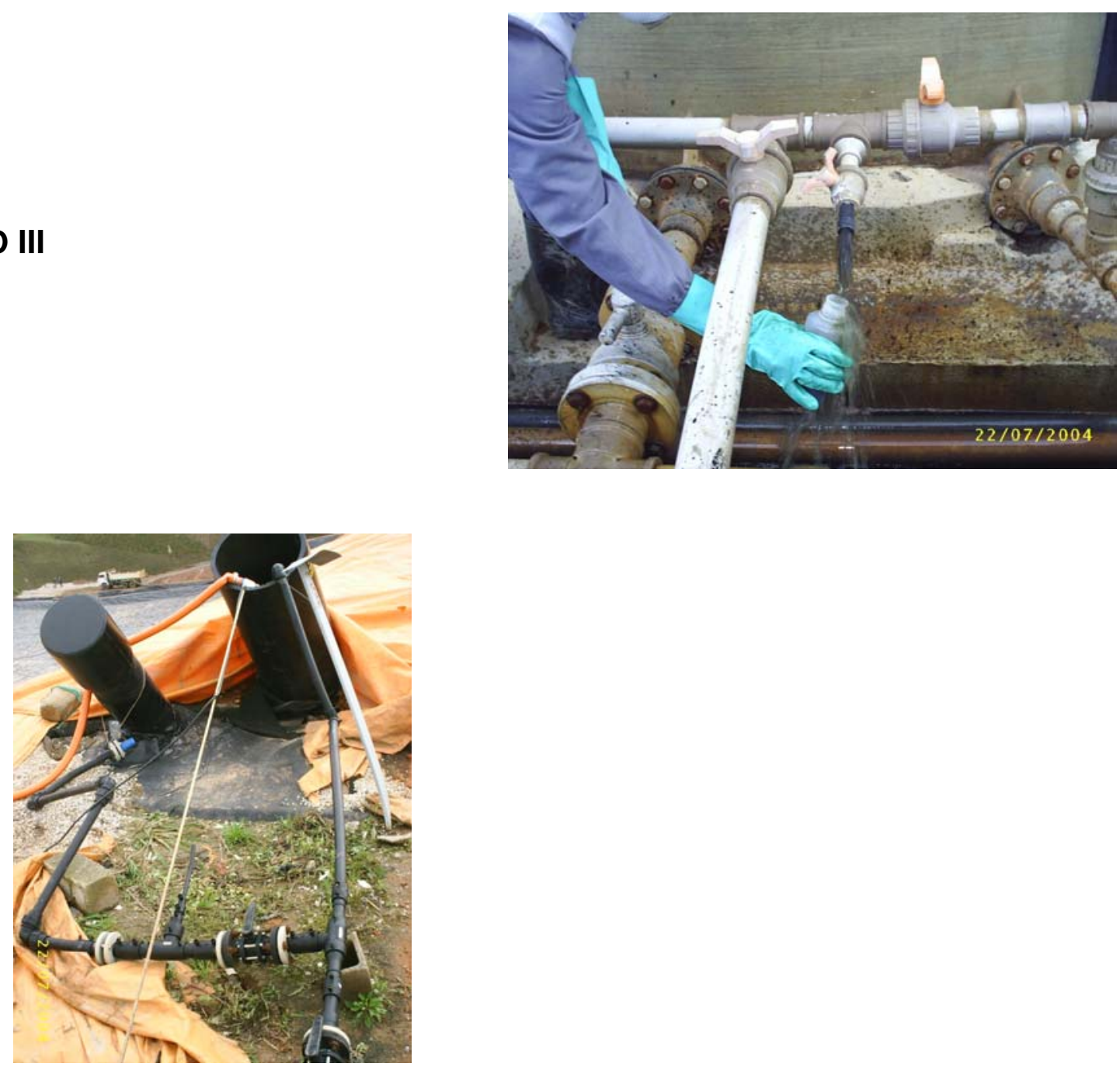

Fotos da coleta e armazenamento do chorume da área de estudo 


\section{8- EXPERIMENTOS COM CHORUMES}

O chorume é um líquido oriundo da decomposição de resíduo pela ação da umidade natural do lixo, águas pluviométricas e líquidos gerados pela ação de microorganismos que atacam a matéria orgânica. O volume de chorume pode aumentar em função de águas infiltradas no interior do aterro resultantes de fontes externas como, por exemplo, águas pluviais. Essas águas carregam consigo parte do chorume ao mesmo tempo em que solubilizam constituintes nocivos dos resíduos, desta forma, se os chorumes não forem coletados e destinados adequadamente, podem comprometer o lençol freático e/ou cursos d'água.

Assim como a qualidade do chorume está condicionada a fatores que resultam em uma composição química variável, dependendo, principalmente do tipo de resíduo presente no aterro, escoamento superficial, infiltração, evapotranspiração e temperatura, a quantidade também é muito variada principalmente em função dos fatores climáticos. Os aterros estudados apresentam, em média, vazão de $380 \mathrm{~m}^{3} /$ dia (Santo André), $430 \mathrm{~m}^{3} /$ dia (Mauá) até $920 \mathrm{~m}^{3} / \mathrm{dia}$ (Tremembé)de chorume.

Tão importante quanto descartar os resíduos sólidos de forma adequada, é o tratamento do chorume. Como a quantidade e qualidade dos chorumes são bastante variáveis torna-se difícil traçar planos para seu reaproveitamento, sendo este um dos principais objetivos deste trabalho.

Vários dos íons detectados nas amostras de chorume são requeridos pelos solos agrícolas, como é citado na síntese bibliográfica a seguir:

Cerca de dezessete elementos são considerados essenciais para o crescimento vegetal, além de fatores como luz, água, fixação mecânica, calor e 
nutrientes. Os macronutrientes utilizados em grande quantidade pelas plantas podem ser adquiridos através do ar e da água do solo, como, por exemplo, carbono, oxigênio e hidrogênio, enquanto os demais, nitrogênio, fósforo, potássio, cálcio, magnésio e enxofre são obtidos do solo. Outras frações importantes dos nutrientes requeridos pelas plantas, em pequenas quantidades, são os micronutrientes - ferro, manganês, boro, molibdênio, cobre, zinco, cloro e cobalto (MALAVOLTA, 1994).

Os macronutrientes nitrogênio, fósforo, potássio, cálcio, magnésio e enxofre são absorvidos, pelas plantas, em tamanha quantidade que a maioria dos solos não conseguem suprir essa demanda, sendo então necessário a adição de fertilizantes. No caso do cálcio e magnésio, por exemplo, o acréscimo de calcário é satisfatório para repor esses elementos.

A estrutura sólida do solo é, na realidade, um reservatório de nutrientes que, a longo prazo, por intermédio de processos intempéricos permite que os elementos essenciais migrem para a fração coloidal e/ou líquida do solo.

Outra parte de nutrientes em quantidades menores que os presentes nas estruturas sólidas estão associados aos colóides e ainda uma terceira porção encontra-se disponível na solução do solo, contudo em quantidades diminutas e ainda suscetíveis a lixiviação (BRADY, 1989).

No QUADRO 8.1 é possível ilustrar a quantidade de nutrientes disponíveis em relação ao total presente no solo, para alguns íons.

QUADRO 8.1 - Quantidade de nutrientes disponíveis, no solo, em relação ao total presente.

\begin{tabular}{|c|c|c|c|}
\hline \multirow{2}{*}{ Elemento } & \multicolumn{3}{|c|}{ Quilos por hectare com 15 cm de profundidade } \\
\cline { 2 - 4 } & Estrutura sólida & Fração permutável & Solução do solo \\
\hline $\mathrm{Ca}^{2+}$ & 6.000 & 2.000 & $50-100$ \\
\hline $\mathrm{Mg}^{2+}$ & 6.600 & 400 & $10-30$ \\
\hline $\mathrm{K}^{1+}$ & 33.800 & 200 & $10-30$ \\
\hline
\end{tabular}

Fonte: BRADY, 1989 
A disponibilidade de nutrientes para o solo pode ser constatada na FIGURA 8.1.

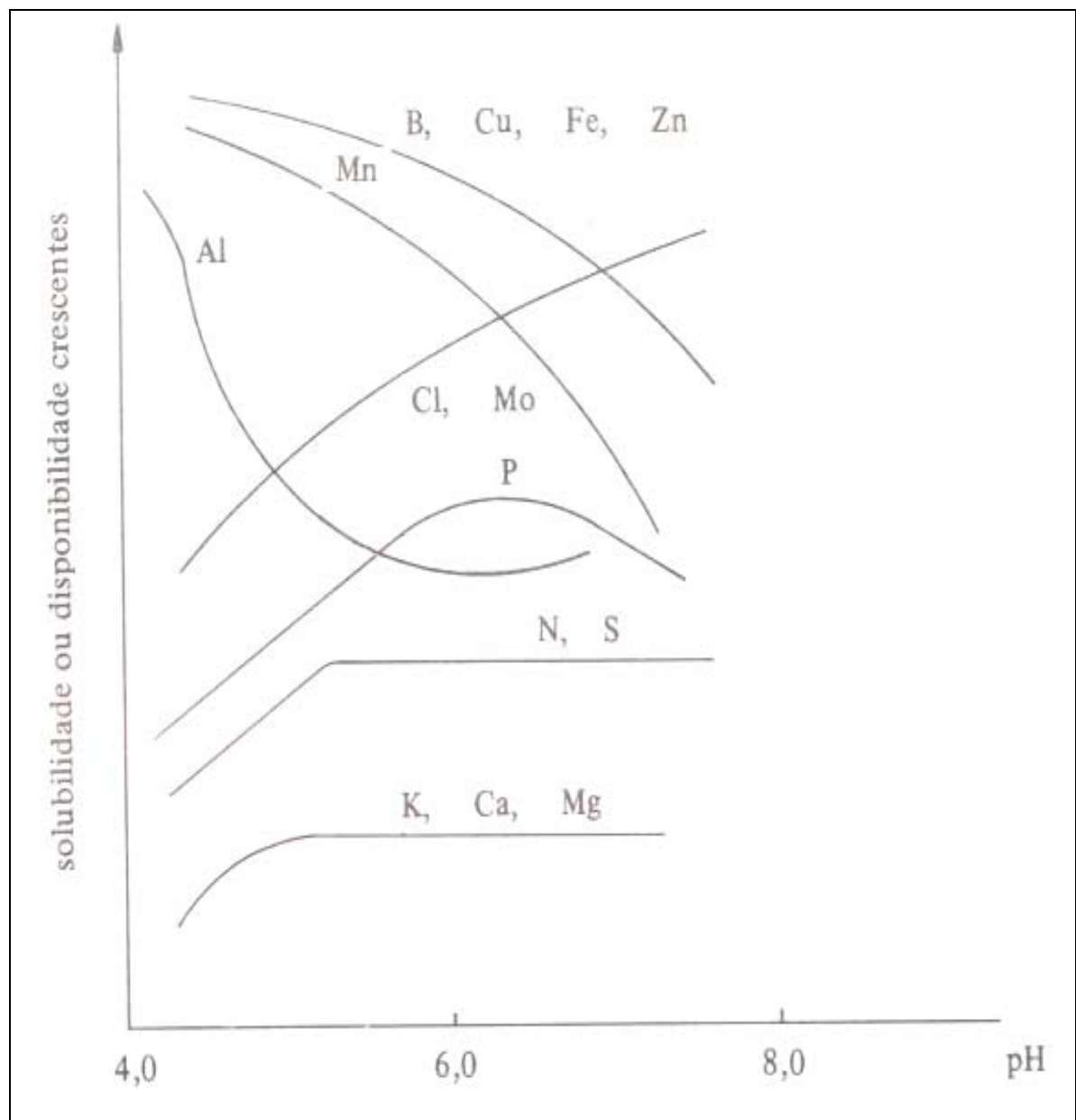

FIGURA 8.1 - Influência do pH na disponibilidade de nutrientes do solo (MELLO et al., 1983)

Elementos com maior solubilidade como ferro, manganês, boro, cobre, zinco e fósforo, acham-se associados a ambientes com condições ligeiramente ácidos.

Caso o meio atinja $\mathrm{pH}$ inferior a 5,5 sérios problemas de toxicidade poderão ocorrer para as plantas em função da solubilidade do alumínio, ferro e 
manganês. Por outro lado, a elevação de pH tornam esses elementos e outros micronutrientes indisponíveis para as plantas.

Os macronutrientes potássio, cálcio, magnésio, enxofre e nitrogênio não apresentam alterações significativas com o aumento de $\mathrm{pH}$.

A seguir apresenta-se uma síntese dos elementos, de interesse neste trabalho, e sua importância no solo.

Juntamente com nitrogênio e fósforo, o potássio forma um importante trio de elementos presentes nas fórmulas dos fertilizantes mais comumente utilizados.

O potássio oriundo de minerais, como feldspatos, micas etc., podem ser, durante o intemperismo, prontamente assimilável pelas plantas (BRADY, 1989).

Quando é acrescentado ao solo com fertilizantes, principalmente na forma de cloretos e sulfatos, grande quantidade permanece adicionada aos colóides, transformando alguns íons permutáveis na forma não permutável; desta forma eles não sofrem lixiviação.

Os tipos de argila presentes no solo influenciam também na disponibilidade do potássio. As argilas caulinitas, do tipo 1:1, apresentam baixa tendência de fixá-lo, contrário às argilas do tipo 2:1 que fixam rapidamente e em grandes quantidade, como as montmorilonita.

Calagem moderada também pode aumentar o poder de fixação do potássio, entretanto em solos ricos em carbonato de cálcio, têm-se verificado deficiência de absorção do potássio, por parte dos vegetais.

O magnésio é mais freqüentemente encontrado nos solos de texturas finas de regiões áridas e semi-áridas.

No solo, o magnésio pode aparecer como constituinte da rede cristalina de alguns argilominerais, fixado, de modo semelhante ao potássio, ou ainda na matéria orgânica. Entretanto, a forma mais assimilada pelas plantas ocorre na forma catiônica adsorvida ao solo (MELLO et al., 1983). 
Em solos ácidos o magnésio geralmente é o terceiro cátion mais trocável, excedido apenas pelo hidrogênio e pelo cálcio, enquanto, nas regiões áridas e semi-áridas, aparece como segundo mais trocável, logo após o cálcio (MELLO et al., 1983).

É difícil encontrar casos na literatura que descrevem excesso de magnésio em solo, bem como seus efeitos, em contra partida, a falta desse elemento afeta não somente plantas como age diretamente na dieta de animais, como, por exemplo, a tetania do pasto, doença que ataca animais cuja alimentação baseia-se em gramíneas pobres em magnésio (MELLO et al., 1983).

O manganês na solução do solo pode se apresentar na forma iônica ou combinado com compostos orgânicos solúveis. Pode formar íons simples e complexos na solução do solo e também diversos óxidos de composição variável. Estes óxidos, na sua maioria, são amorfos, podendo também ocorrer algumas formas cristalinas já identificadas em diversos solos. Os óxidos são os principais compostos a manter as reações de equilíbrio entre as fases sólida e líquida e, em função das condições do pH e do potencial redox, mantêm e controlam a atividade das formas iônicas na solução do solo.

As plantas absorvem o manganês na forma iônica e o suprimento ás raízes é efetuada por fluxo de massa e por difusão. Estes processos são muito efetuados pela concentração do elemento na solução do solo, a qual é influenciada pelo $\mathrm{pH}$, potencial redox, atividade microbiana e teor de matéria orgânica.

$\mathrm{O}$ aumento dos valores de $\mathrm{pH}$ do solo, por exemplo, pela calagem, assim como aumento nos teores de matéria orgânica, podem reduzir significativamente a disponibilidade do manganês (LINDSAY, 1972).

O manganês e o alumínio, em condições naturais, estão entre os dois elementos que mais apresentam toxicidade às plantas. As situações mais comuns que elevam a toxicidade do $\mathrm{Mn}$ são a prática de adubação não acompanhada da correção da acidez, como por exemplo, quando adubos nitrogenados não nítricos, no processo de nitrificação, geram $\mathrm{H}^{+}$aumentando o pH 
do solo e a disponibilidade deste elemento. A destruição da matéria orgânica que forma complexo com o manganês pode também aumenta sua disponibilidade (LINDSAY, 1972).

O sódio é encontrado freqüentemente no solo, em regiões áridas, onde normalmente a evaporação é maior que a precipitação pluviométrica (WALTER, 1986). Nessas condições sais solúveis e $\mathrm{Na}^{+}$trocável acabam se acumulando em quantidades inapropriadas para as plantas.

Segundo UNITED STATES SALINITY LABORATORY STAFF USSL (1954), os solos com quantidades elevadas de sódio podem ser classificados em três categorias:

- Solos salinos: apresentam condutividade do extrato de saturação maior que $4 \mathrm{mmhos} / \mathrm{cm}\left(25^{\circ} \mathrm{C}\right)$, porcentagem de $\mathrm{Na}^{+}$trocável menor que $15 \mathrm{e} \mathrm{pH}$ entre 7,0 e 8,5. A lavagem desse solo com quantidades abundantes de água ajudariam na eliminação do sódio;

- Solos salinos alcalinos: apresentam condutividade do extrato de saturação maior que $4 \mathrm{mmhos} / \mathrm{cm}\left(25^{\circ} \mathrm{C}\right)$, porcentagem de $\mathrm{Na}^{+}$trocável maior que $15 \mathrm{e} \mathrm{o} \mathrm{pH}$ dificilmente ultrapassa 8,5. O excesso de $\mathrm{Na}^{+}$pode ser removido pela substituição de $\mathrm{Ca}^{2+}$ ou $\mathrm{Mg}^{2+}$. Normalmente os corretivos sulfurados fornecem cálcio ou solubilizam o já existente no solo e em seguida recomenda-se a aplicação de muita água para arrastar o $\mathrm{Na}^{+}$deslocado;

- Solos alcalinos não salinos: apresentam condutividade do extrato de saturação menor que $4 \mathrm{mmhos} / \mathrm{cm}\left(25^{\circ} \mathrm{C}\right)$, porcentagem de $\mathrm{Na}^{+}$trocável maior que 15 e pH acima de 8,5.

Altos teores de sódio podem contribuir para a salinidade do solo, dentre eles, rega com água salina, em especial em solos com drenagem inadequada (MARTINS et al., 2005).

O Departamento de Agricultura Norte Americano utiliza uma expressão para determinar o grau de adsorção de sódio pelo solo, denominada SAR: 


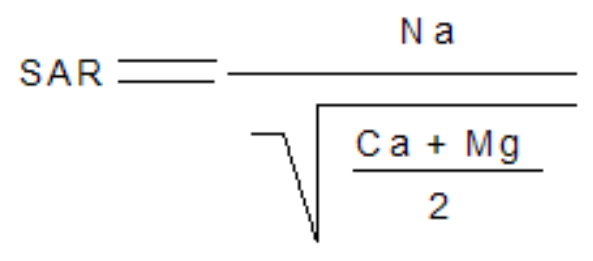

Valores obtidos no SAR < de 10 são considerados de baixo risco para o solo; valores entre 10 e 18 são considerados de risco médio; de 18 a 26 ricos forte e acima de 26 risco muito forte.

A USSL desenvolveu um modelo para a classificação da qualidade de água, utilizadas na agricultura, que estabelece relação entre a condutividade elétrica e o SAR (FIGURA 8.2).

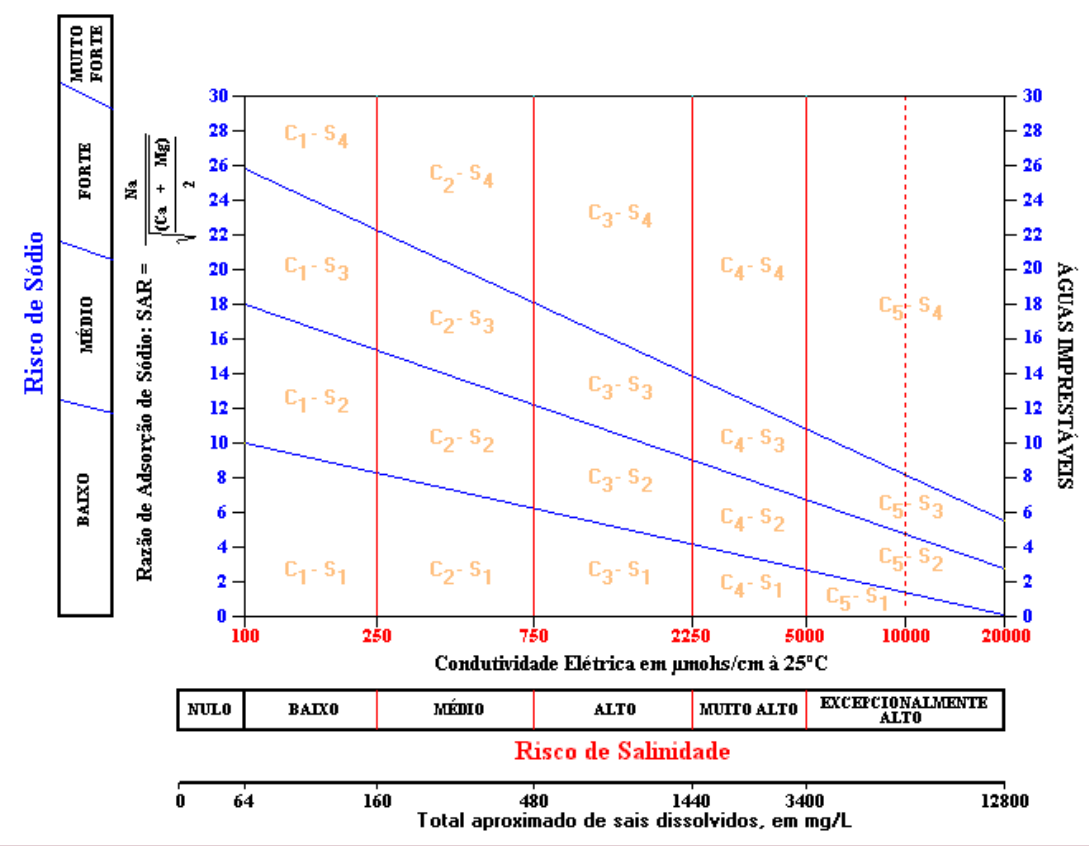

FIGURA 8.2 - Classificação da qualidade das águas utilizadas na agricultura Fonte: UNITED STATES SALINITY LABORATORY STAFF - USSL (1954)

O cálcio na forma de carbonato de cálcio, seguido pelo sulfato de cálcio são amplamente encontrados em regiões áridas. A forma trocável encontra- 
MOURA, C.L. (2008). ÍONS METÁLICOS (AI, Fe, Mn e Pb) ASSOCIADOS A ATERROS (SANITÁRIO E INDUSTRIAL) NO MUNICÍPIO DE TREMEMBÉ/SP.

se adsorvida aos colóides e representa para os solos do Estado de São Paulo, quase na sua totalidade, na forma trocável (MELLO et al., 1983).

Através da calagem é possível, além de neutralizar o solo, também fornecer cálcio à planta. Os principais materiais utilizados para a calagem são o óxido de cálcio e hidróxido de cálcio (JORGE, 1983).

Devem-se ter cuidados especiais com o excesso de calagem, uma vez que elevação do $\mathrm{pH}$ a níveis acima da faixa de neutralidade cria condições propícias à insolubilização do fósforo e de outros micronutrientes, bem como a lixiviação de sulfatos que se acham adsorvidos aos colóides dos solos (JORGE op. cit., 1983).

\section{1 - CHORUME: COLETA E DADOS ANALÍTICOS}

Para a parte experimental não foi levado em consideração o efluente gerado no Aterro Industrial (D) em função da baixa produção de material gerado.

Os experimentos laboratoriais foram realizados com misturas dos chorumes dos Aterros A, B e C (CHORUME I) e de outros dois de diferentes procedências (CHORUME II e III) dos Municípios de Mauá e Santo André, SP.

Nos aterros A, B e C os chorumes são coletados através de tubulações e armazenados em tanques com aproximadamente $500 \mathrm{~m}^{3}$ (FIGURA 8.3 a). Destes tanques foram, coletados cerca de $20 \mathrm{~L}$ do chorume sem tratamento (chorume bruto), em dois períodos distintos, seco e chuvoso. As amostras foram armazenadas em frascos de polietileno e conservadas em caixas termoisolantes a $4^{\circ} \mathrm{C}$. 
A Empresa normalmente envia parte do chorume em caminhõestanque, para a Companhia de Saneamento Básico do Estado de São Paulo (SABESP) para serem tratados juntamente com esgoto. Parte do chorume (cerca de $20 \mathrm{~m}^{3} / \mathrm{dia}$, valor correspondente a um caminhão-tanque) é seco, utilizando como fonte de energia o próprio gás gerado nos aterros e o material resultante desta queima (torta) retorna ao aterro.

Para este trabalho a coleta foi efetuada em uma das tubulações (FIGURA 8.3 b) utilizada para transferir os chorumes para caminhões-tanque e destinados para Estações de Tratamento de Efluentes da SABESP. Ressalta-se que a coleta desse chorume ocorreu depois que o mesmo já estava armazenado algum tempo nos tanques possibilitando a decantação do material em suspensão, situação distinta para os outros dois chorumes que foram coletados diretamente nos aterros.

As amostras de chorume I eram de aspecto denso, de cor verde escura, com material em suspensão em grande quantidade e forte odor desagradável.

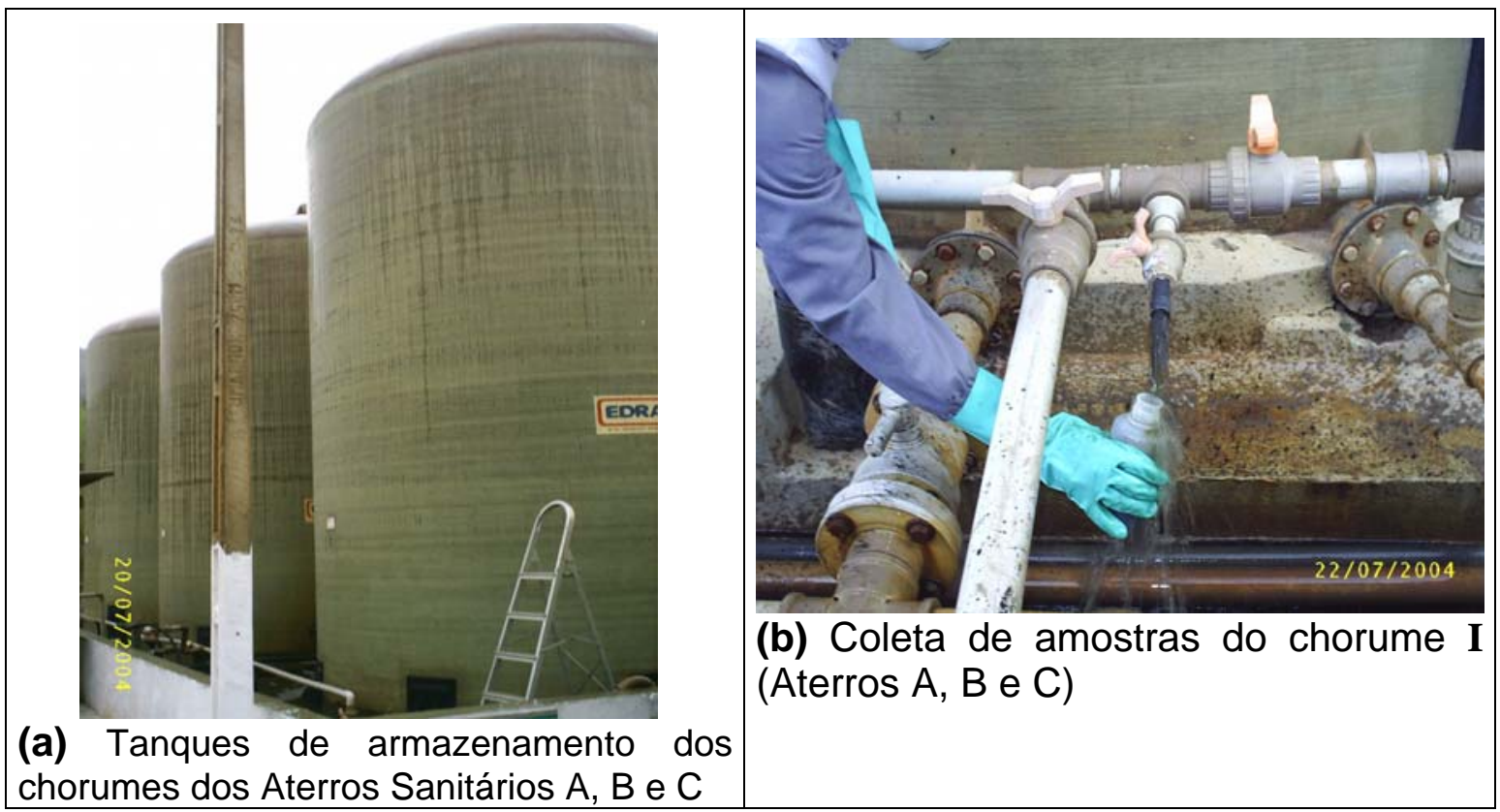

FIGURA 8.3 - Estocagem (a) e coleta (b) de amostras de chorume dos Aterros A, B e C 
Nas coletas dos chorumes II e III, também realizadas em dois períodos, foram obtidas amostras antes e depois do tratamento. Elas foram armazenadas em frascos de polietileno de $1 \mathrm{~L}$ foram acondicionadas em caixas termoisolantes a temperatura de $4^{\circ} \mathrm{C}$.

O chorume II é enviado para lagoas de equalização para homogeneização e controle da vazão. Em seguida são encaminhados para uma lagoa na qual adicionam-se carvão ativado, fosfatos, hidróxido de sódio e constante corrente de ar; em seguida, o lodo passa por uma fase de digestão. $\mathrm{O}$ lodo, aerado e decantado, produz um sobrenadante que é uma mistura composta essencialmente por $\mathrm{H}_{2} \mathrm{O}$. O lodo decantado é enviado para filtro prensa e a torta destinada ao aterro, enquanto o efluente tratado é descartado para um corpo hídrico receptor.

O chorume III passa por um processo de tratamento convencional composto por lagoas de equalização e, neste caso, sem utilização de carvão ativado. O lodo depois de digerido é encaminhado para os aterros, enquanto que o efluente tratado é descartado.

Os chorumes II e III, após tratamentos, são descartados no corpo hídrico receptor, obedecendo a Legislação Estadual e Federal, art. 18 do Decreto Estadual 8468/76 e art. 21 da Resolução 357/05.

Estas amostras possuíam odores desagradáveis, coloração amarelada e maior transparência em relação ao chorume I.

Durante a coleta foram medidos $\mathrm{pH}$ e Eh cujos resultados encontram-se na TABELA 8.1. 
MOURA, C.L. (2008). ÍONS METÁLICOS (AI, Fe, Mn e Pb) ASSOCIADOS A ATERROS (SANITÁRIO E INDUSTRIAL) NO MUNICÍPIO DE TREMEMBÉ/SP.

TABELA 8.1 - Valores de pH e Eh (V) das amostras de chorumes I (Tremembé), II (Mauá) e III (Santo André)

\begin{tabular}{c|c|c|c|c|c|c|c|c|c|c}
\hline \multicolumn{2}{c}{ Chorume I } & \multicolumn{4}{c|}{ Chorume II } & \multicolumn{4}{c}{ Chorume III } \\
\hline & \multicolumn{2}{c|}{ Bruto } & \multicolumn{2}{c}{ Bruto } & \multicolumn{2}{c}{ Tratado } & \multicolumn{2}{c}{ Bruto } & \multicolumn{2}{c}{ Tratado } \\
\hline Período & seco & chuvoso & seco & chuvoso & seco & chuvoso & seco & chuvoso & seco & chuvoso \\
\hline pH & 8,05 & 8,36 & 8,36 & 8,00 & 7,65 & 7,45 & 8,82 & 8,03 & 8,23 & 7,99 \\
\hline Eh & $-0,33$ & $-0,44$ & $-0,28$ & $-0,36$ & $-0,14$ & $-0,12$ & $-0,32$ & $-0,38$ & $-0,29$ & $-0,40$ \\
\hline
\end{tabular}

Amostras dos chorumes coletados foram filtradas e destinadas às análises químicas. Para as determinações analíticas dos ânions, as amostras foram previamente tratadas com $\mathrm{H}_{2} \mathrm{O}_{2}(30 \%)$ à quente para eliminação da matéria orgânica. Os resultados das análises químicas dos cátions e ânions dos chorumes encontram-se na TABELA 8.2 (a) e (b). 
TABELA 8.2 - Dados analíticos $\left(\mathrm{mg}^{\mathrm{d}} \mathrm{dm}^{-3}\right.$ ) dos chorumes brutos (I, II e III) e das lagoas de tratamento (II e III) coletados nos períodos seco e chuvoso

(a) cátions

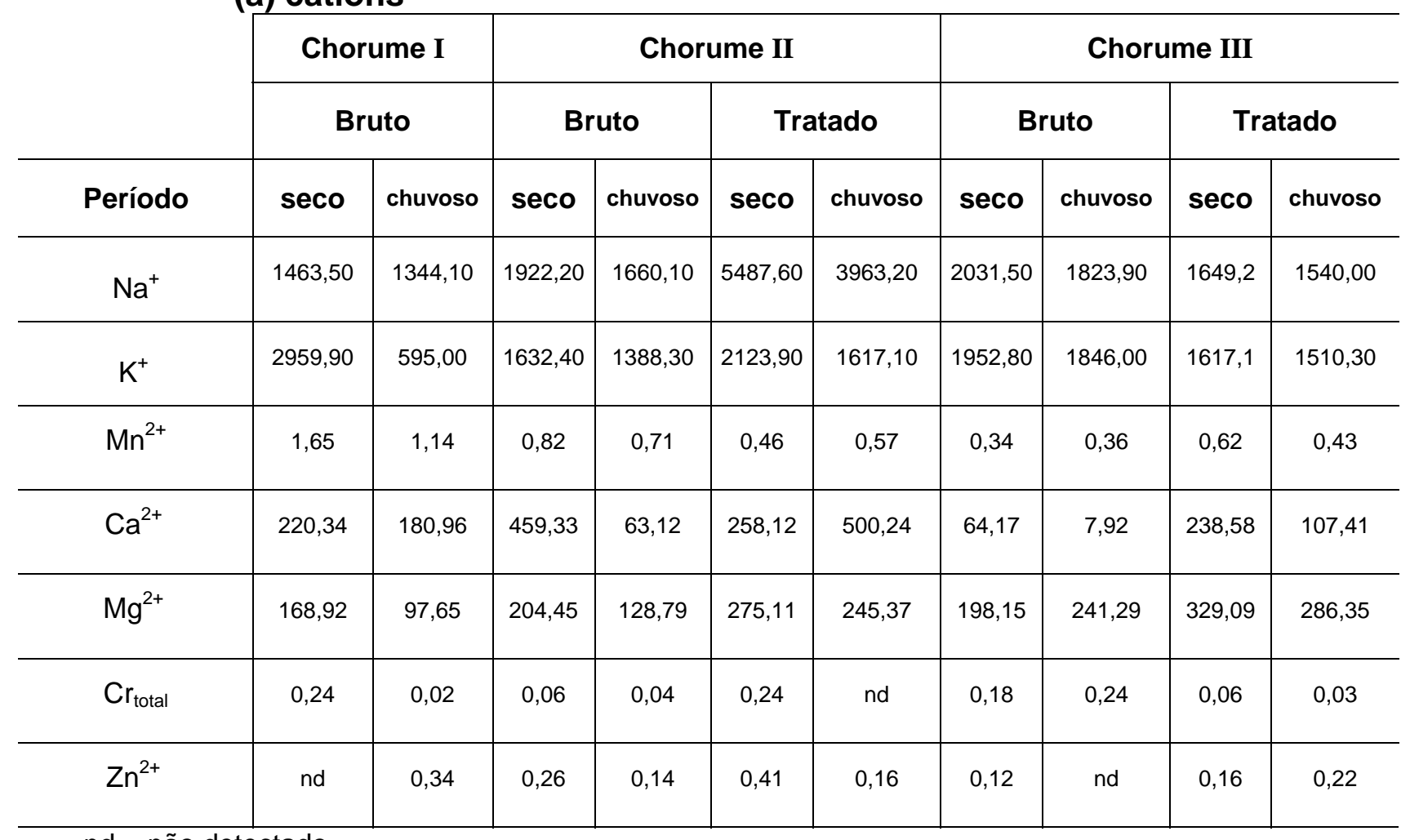

nd = não detectado

Íons de alumínio, ferro, chumbo, cádmio, cobre e nitrito não foram detectados nas amostras de chorume.

(b) ânions

\begin{tabular}{|c|c|c|c|c|c|c|c|c|c|c|}
\hline \multirow[b]{4}{*}{ Período } & 然 & & & & & & & & & \\
\hline & \multirow{2}{*}{\multicolumn{2}{|c|}{$\begin{array}{c}\text { Chorume I } \\
\text { Bruto }\end{array}$}} & \multicolumn{4}{|c|}{ Chorume II } & \multicolumn{4}{|c|}{ Chorume III } \\
\hline & & & \multicolumn{2}{|c|}{ Bruto } & \multicolumn{2}{|c|}{ Tratado } & \multicolumn{2}{|c|}{ Bruto } & \multicolumn{2}{|c|}{ Tratado } \\
\hline & seco & chuvoso & seco & chuvoso & seco & chuvoso & seco & chuvoso & seco & chuvoso \\
\hline $\mathrm{Cl}^{-}$ & 1860,0 & 1509,0 & 2084,7 & 1765,1 & 4645,0 & 2761,0 & 2766,0 & 2528,0 & 2022,0 & 1285,0 \\
\hline $\mathrm{NO}_{3}^{-}$ & 10,60 & 1,700 & 178,00 & 307,00 & 12500,0 & 7815,00 & 348,00 & 201,30 & 113,20 & 185,10 \\
\hline $\mathrm{HPO}_{4}^{2-}$ & 40,20 & 2,60 & 14,40 & 138,00 & 191,00 & 187,90 & 80,20 & 29,29 & 15,30 & 4,73 \\
\hline
\end{tabular}




\section{2 - EXPERIMENTOS}

Os chorumes brutos coletados dos três Aterros Sanitários de Tremembé, bem como de Mauá e Santo André, também brutos e tratados, foram divididos em duas alíquotas, uma delas foi mantida no estado original e outra filtrada (filtros de filtragem rápida) represando o material em suspensão.

Amostras de $3 \mathrm{~L}$ de cada chorume, foram, inicialmente, aquecidas em béqueres de vidro em banho-maria até redução do volume a 1/4. Em seguida elas foram transferidas para cápsulas de porcelana taradas e secas a $100-110^{\circ} \mathrm{C}$ até peso constante (FIGURA 8.4 a e b). As massas resultantes do aquecimento encontram-se na TABELA 8.3. Esses dados permitiram que se calculasse a massa correspondente de $20 \mathrm{~m}^{3}$, ou seja, volume de 1 dia de aquecimento de chorume (TABELA 8.4).

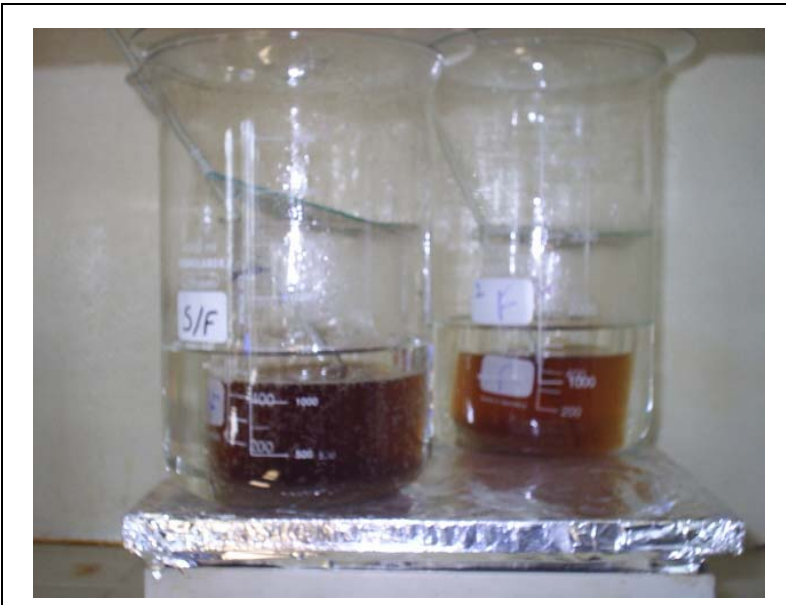

(a) Aquecimento do chorume em banhomaria

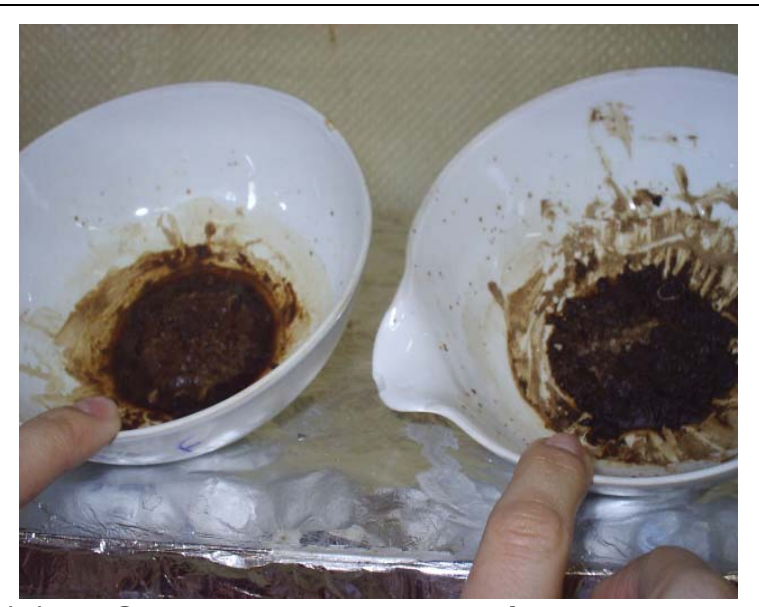

(b) Secagem, em cápsulas de porcelana, do resíduo gerado no aquecimento do chorume

FIGURA 8.4 - Tratamento do chorume para eliminação da fração líquida 
TABELA 8.3 - Massa (g) dos resíduos do aquecimento de 3 L de chorume

\begin{tabular}{|c|c|c|c|c|c|c|c|c|c|c|}
\hline \multicolumn{2}{|c|}{ Chorume I } & \multicolumn{4}{c|}{ Chorume II } & \multicolumn{5}{c}{ Chorume III } \\
\hline & \multicolumn{2}{|c|}{ Chorume Bruto } & \multicolumn{2}{c|}{ Chorume Bruto } & \multicolumn{2}{c|}{ Chorume Tratado } & Chorume Bruto & \multicolumn{2}{c}{ Chorume Tratado } \\
\cline { 2 - 10 } & $\begin{array}{c}\text { sem } \\
\text { filtrar }\end{array}$ & filtrado & $\begin{array}{c}\text { sem } \\
\text { filtrar }\end{array}$ & filtrado & $\begin{array}{c}\text { sem } \\
\text { filtrar }\end{array}$ & filtrado & $\begin{array}{c}\text { sem } \\
\text { filtrar }\end{array}$ & filtrado & $\begin{array}{c}\text { sem } \\
\text { filtrar }\end{array}$ & filtrado \\
\hline $\begin{array}{c}\text { Período seco } \\
\text { Massa (g) }\end{array}$ & 145,20 & 101,91 & 39,00 & 28,06 & 80,24 & 54,18 & 43,09 & 34,13 & 49,67 & 26,49 \\
\hline $\begin{array}{c}\text { Período } \\
\text { chuvoso } \\
\text { Massa (g) }\end{array}$ & 113,18 & 85,11 & 36,02 & 32,02 & 58,58 & 54,18 & 29,71 & 28,27 & 29,43 & 27,20 \\
\hline
\end{tabular}

TABELA 8.4 - Massa $(\mathrm{kg})$ calculada do resíduo do produto do aquecimento de $20 \mathrm{~m}^{3}$ de chorume

\begin{tabular}{|c|c|c|c|c|c|c|c|c|c|c}
\cline { 2 - 10 } \multicolumn{1}{c|}{} & \multicolumn{2}{c|}{ Chorume I } & \multicolumn{3}{c|}{ Chorume II } & \multicolumn{4}{c}{ Chorume III } \\
\cline { 2 - 11 } & \multicolumn{2}{c|}{ Chorume Bruto } & \multicolumn{2}{c|}{ Chorume Bruto } & Chorume Tratado & \multicolumn{2}{c|}{ Chorume Bruto } & \multicolumn{2}{c}{ Chorume Tratado } \\
\hline & $\begin{array}{c}\text { sem } \\
\text { filtrar }\end{array}$ & filtrado & $\begin{array}{c}\text { sem } \\
\text { filtrar }\end{array}$ & filtrado & $\begin{array}{c}\text { sem } \\
\text { filtrar }\end{array}$ & filtrado & $\begin{array}{c}\text { sem } \\
\text { filtrar }\end{array}$ & filtrado & $\begin{array}{c}\text { sem } \\
\text { filtrar }\end{array}$ & filtrado \\
\hline Período seco & 968,11 & 679,48 & 260,03 & 187,09 & 534,99 & 361,24 & 287,30 & 227,56 & 331,17 & 176,62 \\
\hline Período chuvoso & 754,62 & 567,46 & 240,16 & 213,55 & 390,58 & 361,24 & 198,09 & 188,49 & 196,22 & 181,35 \\
\hline
\end{tabular}

O aquecimento do chorume reduziu drasticamente seu volume, conforme demonstrado na TABELA 8.5.

TABELA 8.5 - Porcentagens de eliminação da fração líquida do aquecimento dos chorumes

\begin{tabular}{|c|c|c|c|c|c|c|c|c|c|c}
\hline \multicolumn{2}{|c|}{ Chorume I } & \multicolumn{5}{c|}{ Chorume II } & \multicolumn{5}{c}{ Chorume III } \\
\hline & \multicolumn{2}{|c|}{ Chorume Bruto } & \multicolumn{2}{c|}{ Chorume Bruto } & \multicolumn{2}{c|}{ Chorume Tratado } & \multicolumn{2}{c|}{ Chorume Bruto } & \multicolumn{2}{c}{ Chorume Tratado } \\
\cline { 2 - 12 } & $\begin{array}{c}\text { sem } \\
\text { filtrar }\end{array}$ & filtrado & $\begin{array}{c}\text { sem } \\
\text { filtrar }\end{array}$ & filtrado & $\begin{array}{c}\text { sem } \\
\text { filtrar }\end{array}$ & filtrado & $\begin{array}{c}\text { sem } \\
\text { filtrar }\end{array}$ & filtrado & $\begin{array}{c}\text { sem } \\
\text { filtrar }\end{array}$ & filtrado \\
\hline Período seco & 95,08 & 96,54 & 98,33 & 98,80 & 96,57 & 97,68 & 97,97 & 98,39 & 97,66 & 98,75 \\
\hline Período chuvoso & 96,16 & 97,12 & 98,46 & 98,63 & 97,50 & 97,68 & 98,60 & 98,67 & 98,62 & 98,72 \\
\hline
\end{tabular}


MOURA, C.L. (2008). ÍONS METÁLICOS (AI, Fe, Mn e Pb) ASSOCIADOS A ATERROS (SANITÁRIO E INDUSTRIAL) NO MUNICÍPIO DE TREMEMBÉ/SP.

Com a eliminação da fração líquida, o volume do chorume a ser transportado passa a ser cerca reduzido em $96 \%$ sua massa.

O material sólido foi analisado quimicamente através da Espectrofotometria por Fluorescência de Raios $X$ cujos resultados são apresentados na TABELA 8.6 (a) e (b) para os constituintes maiores e dos elementos traço das amostras filtradas e não filtradas, respectivamente.

Os teores de ferro, alumínio, cobre, chumbo e manganês não aparecem na tabela por apresentarem valores negligenciáveis. 
TABELA 8.6 - Análises químicas (FRX) dos constituintes maiores e elementostraço $\left(\mathrm{mg} \mathrm{kg}^{-1}\right)$ do resíduo gerado no aquecimento dos chorumes.

\section{(a) amostras filtradas}

\begin{tabular}{|c|c|c|c|c|c|c|c|c|c|c|}
\hline \multirow[b]{3}{*}{ Período } & \multirow{2}{*}{\multicolumn{2}{|c|}{$\begin{array}{c}\text { Chorume I } \\
\text { Bruto }\end{array}$}} & \multicolumn{4}{|c|}{ Chorume II } & \multicolumn{4}{|c|}{ Chorume III } \\
\hline & & & \multicolumn{2}{|c|}{ Bruto } & \multicolumn{2}{|c|}{ Tratado } & \multicolumn{2}{|c|}{ Bruto } & \multicolumn{2}{|c|}{ Tratado } \\
\hline & seco & chuvoso & seco & chuvoso & seco & chuvoso & seco & chuvoso & seco & chuvoso \\
\hline $\mathrm{Na}^{+}$ & 11,90 & 19,93 & 13,23 & 13,63 & 18,01 & 16,47 & 12,90 & 11,32 & 12,75 & 12,49 \\
\hline $\mathrm{K}^{+}$ & 12,98 & 4,55 & 11,91 & 11,74 & 7,69 & 6,91 & 12,18 & 11,76 & 13,22 & 12,36 \\
\hline $\mathrm{Ca}^{2+}$ & 0,85 & 0,04 & 0,80 & 1,00 & 0,28 & 0,41 & 0,34 & 0,95 & 0,74 & 0,83 \\
\hline $\mathrm{Mg}^{2+}$ & 2,21 & 0,28 & 1,28 & 1,60 & 0,70 & 0,79 & 1,32 & 1,67 & 1,90 & 2,18 \\
\hline $\mathrm{Cr}_{\text {total }}$ & 29 & nd & 34 & 23 & nd & nd & 28 & 26 & 28 & 26 \\
\hline $\mathrm{Ni}^{2+}$ & 18 & nd & 21 & 12 & 5 & nd & 13 & 12 & 17 & 13 \\
\hline $\mathrm{Zn}^{2+}$ & 19 & nd & 32 & 4 & nd & nd & nd & 11 & 8 & nd \\
\hline $\mathrm{Rb}^{2+}$ & 49 & 29 & 219 & 229 & 154 & 149 & 224 & 206 & 234 & 242 \\
\hline $\mathrm{Sr}^{2+}$ & 31 & 12 & 51 & 66 & 18 & 31 & 40 & 63 & 59 & 79 \\
\hline $\mathrm{P}_{2} \mathrm{O}_{5}(\%)$ & 0,08 & 0,05 & 0,28 & 0,36 & 0,20 & 0,14 & 0,12 & 0,22 & 0,25 & 0,25 \\
\hline $\mathrm{Cl}^{-}$ & 106.601 & 218.847 & 85.610 & 92.996 & 29.661 & 51.815 & 82.960 & 50.403 & 102.105 & 101.952 \\
\hline$S^{2-}$ & 34.842 & 16.220 & 10.395 & 3.118 & 1.616 & 1.940 & 5.258 & 5.504 & 6.275 & 4.706 \\
\hline
\end{tabular}

nd = não detectado 
(b) amostras não filtradas

\begin{tabular}{|c|c|c|c|c|c|c|c|c|c|c|}
\hline \multirow[b]{3}{*}{ Período } & \multirow{2}{*}{\multicolumn{2}{|c|}{$\begin{array}{c}\text { Chorume I } \\
\text { Bruto }\end{array}$}} & \multicolumn{4}{|c|}{ Chorume II } & \multicolumn{4}{|c|}{ Chorume III } \\
\hline & & & \multicolumn{2}{|c|}{ Bruto } & \multicolumn{2}{|c|}{ Tratado } & \multicolumn{2}{|c|}{ Bruto } & \multicolumn{2}{|c|}{ Tratado } \\
\hline & seco & chuvoso & seco & chuvoso & seco & chuvoso & seco & chuvoso & seco & chuvoso \\
\hline $\mathrm{Na}^{+}$ & 22,26 & 20,38 & 13,30 & 13,69 & 18,11 & 15,76 & 12,69 & 9,89 & 12,99 & 20,77 \\
\hline $\mathrm{K}^{+}$ & 2,10 & 3,77 & 11,32 & 11,65 & 7,70 & 6,93 & 12,07 & 11,55 & 12,44 & 2,85 \\
\hline $\mathrm{Ca}^{2+}$ & 0,11 & 0,01 & 0,82 & 1,14 & 0,29 & 0,43 & 0,44 & 1,45 & 0,68 & 0,28 \\
\hline $\mathrm{Mg}^{2+}$ & 0,53 & 0,05 & 1,35 & 1,74 & 0,71 & 0,76 & 1,38 & 1,53 & 1,93 & 0,70 \\
\hline $\mathrm{Cr}_{\text {total }}$ & 18 & 23 & 23 & 30 & 15 & nd & 27 & 26 & 22 & 18 \\
\hline $\mathrm{Ni}^{2+}$ & 9 & 10 & 14 & 14 & nd & 5 & 13 & 15 & 10 & 6 \\
\hline $\mathrm{Zn}^{2+}$ & nd & nd & 15 & 16 & 4 & nd & 4 & 98 & nd & nd \\
\hline $\mathrm{Rb}^{2+}$ & 33 & 37 & 211 & 207 & 146 & 138 & 208 & 190 & 282 & 234 \\
\hline $\mathrm{Sr}^{2+}$ & 17 & 2 & 60 & 73 & 19 & 28 & 45 & 80 & 42 & 78 \\
\hline $\mathrm{P}_{2} \mathrm{O}_{5}(\%)$ & 0,08 & 0,16 & 0,40 & 0,42 & 0,22 & 0,15 & 0,33 & 0,34 & 0,25 & 0,14 \\
\hline $\mathrm{Cl}^{-}$ & 62.134 & 54.838 & 91.780 & 107.457 & 23.157 & 67.059 & 89.626 & 59.688 & 47.248 & 122.537 \\
\hline$S^{2-}$ & 66.453 & 24.239 & 7.077 & 3.634 & 2.201 & 1.781 & 6.045 & 8.458 & 6.544 & 5.369 \\
\hline
\end{tabular}

nd = não detectado

Em seguida, as amostras secas foram submetidas à testes de solubilidade em água e ácido clorídrico (6M) e analisados quimicamente TABELA 8.7 (a e b) para solubilidade em $\mathrm{H}_{2} \mathrm{O}$ e (c e d) para solubilidade em $\mathrm{HCl}$. 
TABELA 8.7 - Resultados analíticos $\left(\mathrm{mg} \mathrm{dm}^{-3}\right)$ dos testes de solubilização com $\mathrm{H}_{2} \mathrm{O}$ e $\mathrm{HCl}$ dos resíduos obtidos pelo aquecimento dos chorumes

\begin{tabular}{|c|c|c|c|c|c|c|c|c|c|c|}
\hline \multirow[b]{3}{*}{ Período } & \multirow{2}{*}{\multicolumn{2}{|c|}{$\begin{array}{c}\text { Chorume I } \\
\text { Bruto } \\
\end{array}$}} & \multicolumn{4}{|c|}{ Chorume II } & \multicolumn{4}{|c|}{ Chorume III } \\
\hline & & & \multicolumn{2}{|c|}{ Bruto } & \multicolumn{2}{|c|}{ Tratado } & \multicolumn{2}{|c|}{ Bruto } & \multicolumn{2}{|c|}{ Tratado } \\
\hline & seco & chuvoso & seco & chuvoso & seco & chuvoso & seco & chuvoso & seco & chuvoso \\
\hline $\mathrm{Na}^{+}$ & 1762,40 & 3279,30 & 1204,70 & 1405,40 & 2142,40 & 2386,20 & 1472,40 & 1517,00 & 1439,30 & 1539,30 \\
\hline $\mathrm{K}^{+}$ & 216,40 & 629,10 & 905,80 & 1132,30 & 729,70 & 805,20 & 1258,10 & 1283,30 & 1484,60 & 1560,10 \\
\hline $\mathrm{Mn}^{2+}$ & 0,49 & 0,24 & 0,56 & 0,15 & 0,57 & 0,35 & 0,47 & 0,46 & 0,56 & 0,56 \\
\hline $\mathrm{Ca}^{2+}$ & 9,81 & 14,44 & 10,11 & 10,24 & 78,30 & 150,34 & 53,74 & 119,51 & 11,53 & 13,18 \\
\hline $\mathrm{Mg}^{2+}$ & 30,17 & 31,45 & 56,60 & 75,39 & 66,13 & 141,31 & 103,52 & 157,06 & 97,63 & 105,58 \\
\hline $\mathrm{Fe}_{\text {total }}$ & 1,26 & 1,23 & 2,54 & 2,69 & 3,88 & 2,20 & 3,19 & 2,71 & 2,51 & 1,64 \\
\hline $\mathrm{Cl}^{-}$ & 1553,10 & 3171,00 & 2153,00 & 2297,00 & 1071,00 & 1233,00 & 2961,00 & 1867,00 & 4421,00 & 1918,00 \\
\hline $\mathrm{Br}^{-}$ & 4,76 & 6,50 & 3,88 & 3,79 & $\mathrm{nr}$ & $\mathrm{nr}$ & 6,52 & 3,52 & 8,90 & 3,94 \\
\hline $\mathrm{NO}_{3}^{-}$ & 46,60 & 65,10 & 64,60 & 85,50 & 328,00 & 365,00 & 57,5 & 44,63 & 114,50 & 39,60 \\
\hline $\mathrm{SO}_{4}^{2-}$ & 1161,00 & 329,5 & 136,30 & 46,60 & 15,50 & 26,30 & 131,10 & 58,30 & 126,10 & 26,80 \\
\hline $\mathrm{HPO}_{4}^{2-}$ & 36,40 & 33,60 & 27,50 & 15,78 & 35,40 & 76,20 & 4,95 & 44,50 & 8,23 & 9,00 \\
\hline
\end{tabular}

$\mathrm{nr}=$ não realizado

Ressalta-se que na solubilidade em água foram detectadas quantidades desprezíveis de alumínio, cobre, chumbo, zinco, cádmio, cromo e nitrito tanto nas amostras filtradas, quanto naquelas não filtradas. 
(b) solubilidade em $\mathrm{H}_{2} \mathrm{O}$ - Amostras não filtradas

\begin{tabular}{|c|c|c|c|c|c|c|c|c|c|c|}
\hline \multirow[b]{4}{*}{ Período } & \\
\hline & \multirow{2}{*}{\multicolumn{2}{|c|}{$\begin{array}{c}\text { Chorume I } \\
\text { Bruto }\end{array}$}} & \multicolumn{4}{|c|}{ Chorume II } & \multicolumn{4}{|c|}{ Chorume III } \\
\hline & & & \multicolumn{2}{|c|}{ Bruto } & \multicolumn{2}{|c|}{ Tratado } & \multicolumn{2}{|c|}{ Bruto } & \multicolumn{2}{|c|}{ Tratado } \\
\hline & seco & chuvoso & seco & chuvoso & seco & chuvoso & seco & chuvoso & seco & chuvoso \\
\hline $\mathrm{Na}^{+}$ & 1851,60 & 3034,00 & 1115,40 & 1360,80 & 2007,80 & 2052,40 & 1204,70 & 1338,50 & 1272,40 & 1404,70 \\
\hline $\mathrm{K}^{+}$ & 171,10 & 603,90 & 805,20 & 1082,00 & 679,40 & 729,70 & 1157,50 & 1107,10 & 1158,80 & 1307,10 \\
\hline $\mathrm{Mn}^{2+}$ & 0,46 & 0,18 & 0,33 & 0,32 & 0,71 & 0,43 & 0,34 & 0,24 & 0,47 & 0,48 \\
\hline $\mathrm{Ca}^{2+}$ & 7,80 & 10,53 & 10,91 & 51,38 & 59,41 & 124,72 & 10,66 & 121,20 & 9,83 & 14,2 \\
\hline $\mathrm{Mg}^{2+}$ & 11,89 & 20,78 & 63,76 & 78,71 & 74,45 & 91,32 & 94,65 & 156,55 & 119,73 & 134,65 \\
\hline $\mathrm{Fe}_{\text {total }}$ & 1,33 & 1,51 & 2,49 & 2,86 & 2,44 & 1,37 & 4,77 & 3,69 & 2,64 & 1,50 \\
\hline $\mathrm{Cl}^{-}$ & 1433,00 & 6385,00 & 1728,00 & NR & 2041,00 & 2042,00 & 1770,00 & 1862,00 & 2153,00 & 1308,90 \\
\hline $\mathrm{Br}^{-}$ & 3,97 & 10,20 & 2,49 & $\mathrm{nr}$ & $\mathrm{nr}$ & nd & 3,87 & 3,77 & 4,99 & 24,20 \\
\hline $\mathrm{NO}_{3}^{-}$ & 25,10 & 50,60 & 46,60 & $\mathrm{nr}$ & 610,00 & 571,00 & 52,20 & 47,60 & 47,80 & 284,80 \\
\hline $\mathrm{SO}_{4}^{2-}$ & 1256,70 & 708,00 & 106,50 & $\mathrm{nr}$ & 60,00 & 31,00 & 98,36 & 124,70 & 88,60 & 282,50 \\
\hline $\mathrm{HPO}_{4}^{2-}$ & 20,30 & 57,50 & 19,80 & $\mathrm{nr}$ & 109,42 & 69,60 & 16,00 & 51,90 & 8,70 & nd \\
\hline
\end{tabular}

Os teores de sódio, magnésio, potássio e cálcio nos testes de solubilidade com água foram superiores, para todas as amostras, no período úmido, o que já era de se espertar, uma vez que esses íons são extremamente solúveis. 


\section{(c) solubilidade em $\mathrm{HCl}$ - Amostras filtradas}

\begin{tabular}{cc|c|c|c|c|c|c|c|c|c} 
& \multicolumn{2}{c}{ Chorume I } & \multicolumn{4}{c|}{ Chorume II } & \multicolumn{4}{c}{ Chorume III } \\
\cline { 2 - 12 } & \multicolumn{2}{c}{ Bruto } & \multicolumn{2}{c|}{ Bruto } & \multicolumn{2}{c|}{ Tratado } & \multicolumn{2}{c}{ Bruto } & \multicolumn{2}{c}{ Tratado } \\
\hline Período & seco & chuvoso & seco & chuvoso & seco & chuvoso & seco & chuvoso & seco & chuvoso \\
\hline $\mathrm{Na}^{+}$ & 2921,60 & 5263,40 & 1639,60 & 1795,00 & 2131,00 & 2463,30 & 1472,00 & 2230,30 & 1334,3 & 1717,30 \\
\hline $\mathrm{K}^{+}$ & 283,20 & 1014,80 & 1321,60 & 1345,20 & 749,60 & 849,60 & 1382,30 & 1968,80 & 1534,0 & 1581,20 \\
\hline $\mathrm{Fe}_{\text {total }}$ & 4,57 & 7,17 & 7,52 & 6,52 & 6,29 & 4,64 & 7,80 & 5,29 & 7,29 & 7,67 \\
\hline $\mathrm{Al}^{3+}$ & 0,40 & 0,65 & 0,98 & 1,00 & 0,43 & 0,40 & 1,31 & 0,79 & 0,66 & 0,77 \\
\hline $\mathrm{Mn}^{2+}$ & 1,30 & 0,41 & 0,53 & 0,32 & 0,34 & 0,21 & 0,07 & 0,92 & 0,31 & 1,05 \\
\hline $\mathrm{Ca}^{2+}$ & 95,49 & 99,16 & 276,55 & 313,93 & 102,87 & 150,45 & 158,81 & 291,74 & 249,36 & 298,12 \\
\hline $\mathrm{Mg}^{2+}$ & 79,58 & 127,35 & 131,36 & 207,84 & 87,89 & 97,48 & 225,48 & 233,54 & 243,98 & 333,19 \\
\hline $\mathrm{Cr}_{\text {total }}$ & 0,94 & 0,33 & 0,21 & 0,19 & 0,22 & 0,12 & 0,31 & 0,09 & 0,27 & 0,04 \\
\hline
\end{tabular}

\section{(d) solubilidade em $\mathrm{HCl}$ - Amostras não filtradas}

\begin{tabular}{c|c|c|c|c|c|c|c|c|c|c} 
& \multicolumn{2}{c}{ Chorume I } & \multicolumn{4}{c|}{ Chorume II } & \multicolumn{4}{c}{ Chorume III } \\
\cline { 2 - 12 } & \multicolumn{2}{c}{ Bruto } & \multicolumn{2}{c|}{ Bruto } & \multicolumn{2}{c|}{ Tratado } & \multicolumn{2}{c}{ Bruto } & \multicolumn{2}{c}{ Tratado } \\
\hline Período & seco & chuvoso & seco & chuvoso & seco & chuvoso & seco & chuvoso & seco & chuvoso \\
\hline $\mathrm{Na}^{+}$ & 3189,30 & 3129,50 & 1672,70 & 3568,40 & 2096,40 & 2453,30 & 1338,20 & 1739,60 & 1561,9 & 1738,90 \\
\hline $\mathrm{K}^{+}$ & 684,40 & 212,40 & 3115,10 & 1274,40 & 853,80 & 778,80 & 1463,20 & 1274,40 & 1604,8 & 1463,20 \\
\hline $\mathrm{Fe}_{\text {total }}$ & 4,96 & 6,72 & 4,50 & 4,75 & 6,54 & 5,42 & 7,43 & 16,88 & 6,93 & 4,59 \\
\hline $\mathrm{Al}^{3+}$ & 0,54 & 0,63 & 0,97 & 1,37 & 0,54 & 0,45 & 1,21 & 3,14 & 0,72 & 1,01 \\
\hline $\mathrm{Mn}^{2+}$ & 0,53 & 0,38 & 0,47 & 0,71 & 0,43 & 0,47 & 0,31 & 1,21 & 0,43 & 0,91 \\
\hline $\mathrm{Ca}^{2+}$ & 2,11 & 10,33 & 295,49 & 346,53 & 31,16 & 148,72 & 159,60 & 433,18 & 249,04 & 277,09 \\
\hline $\mathrm{Mg}^{2+}$ & 17,19 & 78,42 & 153,15 & 238,63 & 99,98 & 125,90 & 156,65 & 219,86 & 221,68 & 335,16 \\
\hline $\mathrm{Cr}_{\text {total }}$ & 0,16 & 0,26 & 0,18 & 0,22 & 0,19 & 0,11 & 0,22 & 0,13 & 0,16 & 0,18 \\
\hline
\end{tabular}


Os produtos resultantes da secagem dos chorumes dos Aterros nos testes de solubilidade com $\mathrm{H}_{2} \mathrm{O}$ e $\mathrm{HCl}$ mostraram comportamento semelhantes com resultados analíticos muito próximos. A solubilidade em meio ácido permitiu a solubilidade maior dos íons ferro, alumínio e manganês, desta forma, sendo recomendável a utilização da água como solvente.

Como se observa, ao se examinarem as análises químicas dos chorumes, os produtos de sua solubilidade contém vários micronutrientes e macronutrientes o que pode permitir seu aproveitamento.

Como os teores de sódio são significativamente elevados calcularam-se os valores da Razão de Absorção de Sódio (SAR), visando sua utilização na lavoura (TABELA 8.8).

TABELA 8.8 - Valores da Razão de Adsorção de Sódio (SAR) dos produtos da secagem dos chorumes brutos e tratados solubilizados em $\mathrm{H}_{2} \mathrm{O}$, dos Aterros I, II e III

\begin{tabular}{c|c|c|c|c|c|c|c|c|c|c}
\cline { 2 - 10 } & \multicolumn{2}{c|}{ Chorume I } & \multicolumn{3}{c|}{ Chorume II } & \multicolumn{4}{c}{ Chorume III } \\
\cline { 2 - 10 } & \multicolumn{2}{c|}{ Bruto } & \multicolumn{2}{c|}{ Bruto } & \multicolumn{2}{c|}{ Tratado } & \multicolumn{2}{c}{ Bruto } & \multicolumn{2}{c}{ Tratado } \\
\hline Período & seco & chuvoso & seco & chuvoso & seco & chuvoso & seco & chuvoso & seco & chuvoso \\
\hline $\begin{array}{c}\text { SAR } \\
\text { (sol. } \mathrm{H}_{2} \mathrm{O}, \\
\text { filtrada) }\end{array}$ & 62,29 & 110,52 & 32,33 & 33,20 & 42,92 & 33,36 & 26,90 & 21,41 & 30,08 & 30,84 \\
\hline $\begin{array}{c}\text { SAR } \\
\text { (sol. } \mathrm{H}_{2} \mathrm{O}, \text { não } \\
\text { filtrada) }\end{array}$ & 96,98 & 124,44 & 28,35 & 27,64 & 40,79 & 33,93 & 25,55 & 18,83 & 24,15 & 25,03 \\
\hline
\end{tabular}

Pelos valores indicados pelo cálculo da Razão de Adsorção de Sódio (SAR) e segundo UNITED STATES SALINITY LABORATORY STAFF - USSL (1954), as amostras resultantes do aquecimento do chorume e dissolução em água são classificadas como C5-S4 o que dificulta que essa solução seja utilizada em solos com deficiência de drenagem, contudo seu uso é permitido para solos com concentrações elevadas de cálcio e/ou para cultivo de plantas com tolerância aos sais. 
No Aterro II parte do material da digestão do lodo de tratamento do chorume é encaminhado para o filtro prensa gerando uma torta que também foi analisada quimicamente por Espectrofotometria por Fluorescência de Raios X. Os resultados encontram-se na TABELA 8.9.

TABELA 8.9 - Análises químicas (DRX) dos constituintes maiores e elementostraço $\left(\mathrm{mg} \mathrm{kg}^{-1}\right)$ do lodo gerado no tratamento do chorume (torta) do ATERRO II

\begin{tabular}{c|c|c|c|c|c|c|c|c|c|c|c|c|c}
\hline $\begin{array}{c}\text { período } \\
\text { Íns }\end{array}$ & $\mathrm{Na}^{+}$ & $\mathrm{K}^{+}$ & $\mathbf{M g}^{2+}$ & $\mathrm{Ca}^{2+}$ & $\mathrm{Cr}_{\text {total }}$ & $\mathbf{C u}^{2+}$ & $\mathbf{N i}^{2+}$ & $\mathbf{Z n}^{2+}$ & $\mathbf{R b}^{2+}$ & $\mathbf{S r}^{2+}$ & $\begin{array}{c}\mathrm{P}_{2} \mathrm{O}_{\mathbf{5}} \\
(\%)\end{array}$ & $\mathbf{C l}$ & $\mathbf{s}^{2+}$ \\
\hline seco & 2,49 & 0,70 & 4,41 & 17,78 & 101 & 13 & 13 & 148 & 10 & 564 & 1,27 & 6291 & 5917 \\
\hline chuvoso & 1,29 & 0,69 & 5,38 & 11,07 & 81 & 9 & 12 & 116 & 12 & 325 & 1,29 & 10164 & 8226 \\
\hline
\end{tabular}

nd = não detectado

Na TABELA 8.10 encontram-se os dados analíticos dos testes de solubilidade com $\mathrm{H}_{2} \mathrm{O}$ das tortas geradas no Aterro II.

TABELA 8.10 - Resultados analíticos $\left(\mathrm{mg} \mathrm{dm}^{-3}\right)$ dos testes de solubilização em $\mathrm{H}_{2} \mathrm{O}$ das tortas obtidas no Aterro II

\begin{tabular}{|c|c|c|c|c|c|c|c|c|c|c|c|}
\hline cátions & $\mathrm{Na}^{+}$ & $\mathrm{K}^{+}$ & $\mathrm{Mg}^{2+}$ & $\mathrm{Ca}^{2+}$ & $\mathrm{Mn}^{2+}$ & $\mathrm{Al}^{3+}$ & $\mathrm{Fe}_{\text {total }}$ & $\mathrm{Cu}^{2+}$ & $\mathrm{Zn}^{2+}$ & $\mathrm{Cd}^{2+}$ & $\mathrm{Cr}_{\text {total }}$ \\
\hline seco & 162,9 & 65,4 & 1,86 & 164,33 & 0,15 & nd & 1,14 & nd & nd & nd & nd \\
\hline úmido & 189,6 & 75,5 & 4,15 & 123,40 & 0,22 & nd & 0,54 & 0,13 & nd & nd & 0,03 \\
\hline ânions & $\mathrm{Cl}^{-}$ & $\mathrm{Br}^{-}$ & $\mathrm{NO}_{2}^{-}$ & $\mathrm{NO}_{3}^{-}$ & $\mathrm{SO}_{4}^{2-}$ & $\mathrm{HPO}_{4}^{2-}$ & & & & & \\
\hline seco & 66,50 & 0,127 & 2,60 & 206,00 & 23,80 & 13,80 & & & & & \\
\hline úmido & 91,72 & 0,139 & ND & 182,00 & 19,30 & 4,63 & & & & & \\
\hline
\end{tabular}

Quando realizados os testes de solubilidade do material resultante do tratamento do chorume do aterro II, verificou-se que a concentração iônica de metais é semelhante ao do material obtido pelo aquecimento dos chorumes, exceto para os íons sódio, com valores extremamente menores. Como esse íon apresenta elevada solubilidade, ele manteve-se dissolvido na solução tratada do chorume. 
Os teores elevados de cálcio e magnésio, em relação ao chorume bruto, são devido ao acréscimo de calcário antes do material ser levado ao filtro prensa.

$\mathrm{O}$ valor calculado de SAR para a solubilidade deste material em $\mathrm{H}_{2} \mathrm{O}$, para os períodos seco e úmido, foi respectivamente 0,56 e 0,57.

Segundo USLL a solubilização das tortas em $\mathrm{H}_{2} \mathrm{O}$ são classificadas como C3-S1 que permitiria a utilização deste material na agricultura.

O resíduo do chorume após secagem apresentou determinados macronutrientes (magnésio, potássio, cálcio e fosfatos) além de micronutrientes (ferro, manganês e cloretos) úteis á agricultura.

Os valores elevados de cloretos acredita-se que não seria motivo de preocupação. MELLO (1993) em seus experimentos com o objetivo de verificar os efeitos da alta concentração de cloretos para as plantas constatou que não existe influência entre teores elevados de cloretos e toxicidade de plantas.

Outra alternativa é o uso das soluções aplicadas em culturas tolerantes a salinização, como bananas dos tipos pacovan e nanicão e a beterraba, como sugerido nos estudos realizados por SANTANA (2000).

A Atriplex nummularia, conhecida como erva-sal, é uma espécie de forrageira halófita muito bem adaptada às condições de regiões áridas e semiáridas. Seu plantio permite seu uso para extração de sais do solo. Os sais absorvidos pela erva-sal, principalmente o $\mathrm{NaCl}$, são acumulados basicamente nas folhas. Experimentos com essa espécie de forrageira têm sido realizados com o objetivo de encontrar soluções para a utilização de rejeitos líquidos ricos em sais, como no caso de efluentes de tratamento de esgoto doméstico ou ainda no caso dos rejeitos de dessalinizadores (HESPANHOL, 2002; MANCUCO \& SANTOS, 2003).

A erva-sal se adapta bem a altas temperaturas, sobrevive bem em solo pobres e com texturas arenosas e com alto valor protéico (FUNCAP, 2001). 
MOURA, C.L. (2008). ÍONS METÁLICOS (AI, Fe, Mn e Pb) ASSOCIADOS A ATERROS (SANITÁRIO E INDUSTRIAL) NO MUNICÍPIO DE TREMEMBÉ/SP.

Em função das suas propriedades de se adaptar em ambientes com alto índice de salinidade e ainda possuir valor nutritivo considerável para alimentação de caprinos, ovinos e bovinos (FUNCAP, 2001), acredita-se que o emprego do resíduo obtido nos experimentos deste trabalho, possa ser utilizado em plantações de erva-sal, e futuramente na alimentação de animais. 


\section{9 - CONCLUSÕES}

Foram estudadas as propriedades do solo, solo/sedimento, sedimento de fundo e chorumes associados a quatro Aterros da Região de Tremembé - três Sanitários e um Industrial. Constatou-se a presença de íons poluentes de metais pesados, alguns muito acima dos padrões de potabilidade da água.

Valores de $\mathrm{pH}$ com características ácidas propiciam maior mobilidade a esses íons, constituindo-se num parâmetro que supera a influência do potencial de óxi-redução com valores sempre positivos imprimindo condições de fixação, principalmente para o ferro e manganês.

Estudos dos atributos do solo indicam também condições inapropriadas para retenção de íons metálicos sendo, portanto, mais um fator de risco que contribui para o comprometimento da área. Na grande maioria o solo possui características franco arenosas e franco argilo-arenosas com capacidade limitada quanto à retenção de íons metálicos. Sua composição mineralógica é basicamente constituída de caulinita com traços de illita e gibbsita. Essa composição associada aos baixos valores de capacidade de troca catiônica confirma a baixa fixação dos íons de metais pesados.

As amostras de solo/sedimento das margens do Rio Serragem, de seu Afluente e do Rio Pimenta são constituídos por sedimentos arenosos, com composição mineralógica também composta essencialmente por caulinita e gibbsita, conseqüentemente com valores baixos de capacidade de troca catiônica, não se mostrando aptas na retenção de íons metálicos.

O sedimento de fundo argilo-arenoso, com teores elevados de matéria orgânica forma o único sistema sólido que concede condições ideais para amenizar a disponibilidade de metais pesados. 
Diante destes resultados e levando em conta que uma porção considerável da população se serve de água para consumo humano extraídas de poços do tipo cacimba, além de regas a hortas, dessedentação de animais e abastecimento de ranários por rios e lago, confirma-se necessidade urgente de controle rigoroso dos agentes poluentes. Este controle poderia se iniciar pela triagem prévia dos resíduos que são encaminhados aos aterros sanitários, principalmente através de eficiente coleta seletiva.

A formação do chorume se deve a percolação de águas pluviométricas que se juntam aos produtos resultantes da decomposição do lixo. $O$ volume líquido gerado é, em média, $10500 \mathrm{~m}^{3} / \mathrm{mês,} \mathrm{o} \mathrm{que} \mathrm{causa} \mathrm{encarecimento}$ no seu descarte devido o transporte em caminhões-pipa para as Estações de Tratamento de Esgoto. Para minimizar esse problema, alguns aterros tratam o chorume no próprio local encaminhando a fase sólida para aterros e o líquido normalmente descartado em rios.

Experimentalmente, neste trabalho, conseguiu-se pela redução média de $96 \%$ do volume do chorume eliminar o problema do transporte e ainda desenvolver um método que propiciará o uso racional do chorume.

Os resíduos sólidos, gerados pela secagem total do chorume, mostraram-se totalmente solúveis em água e os resultados analíticos forneceram teores de macronutrtientes ( $\mathrm{K}, \mathrm{Ca}, \mathrm{Mg}$ e $\mathrm{P}$ ) e micronutrientes (Fe, $\mathrm{Mn} \mathrm{e} \mathrm{Cl}$ ) que podem ser utilizados para fins agrícolas.

Desta forma, esses processos permitem não somente 0 barateamento para o destino final do chorume como, também e principalmente, 0 aproveitamento da solução do produto da secagem do chorume nas regas em solos para plantio.

No processo de irrigação o sódio, pela sua elevada concentração, seria o constituinte limitante para a utilização do resíduo, contudo ele pode ser destinado, por exemplo, em plantios de forrageiras como a erva-sal; trata-se de uma planta bastante utilizada para alimentação de caprinos, ovinos e bovinos, especialmente em regiões áridas. 
MOURA, C.L. (2008). ÍONS METÁLICOS (AI, Fe, Mn e Pb) ASSOCIADOS A ATERROS (SANITÁRIO E INDUSTRIAL) NO MUNICÍPIO DE TREMEMBÉ/SP.

Os Aterros estudados necessitam de constante monitoramento, uma vez que se comprovou o comprometimento da área por metais pesados. Seria ainda de grande interesse que fossem aproveitados os produtos (micro e macro nutrientes) resultantes do tratamento do chorume, como aqui se propõe. 


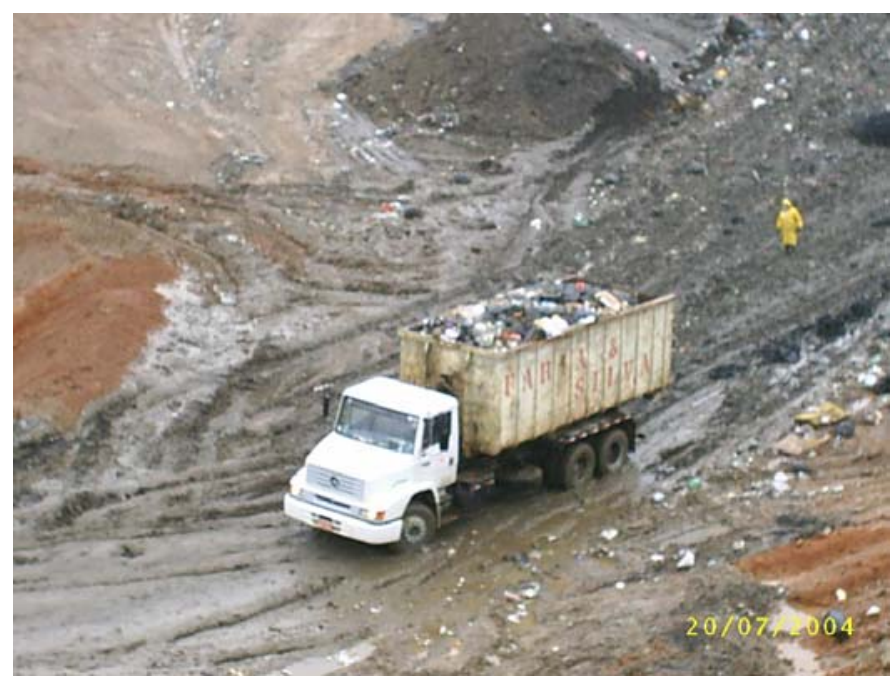

\section{CAPÍTULO IV}
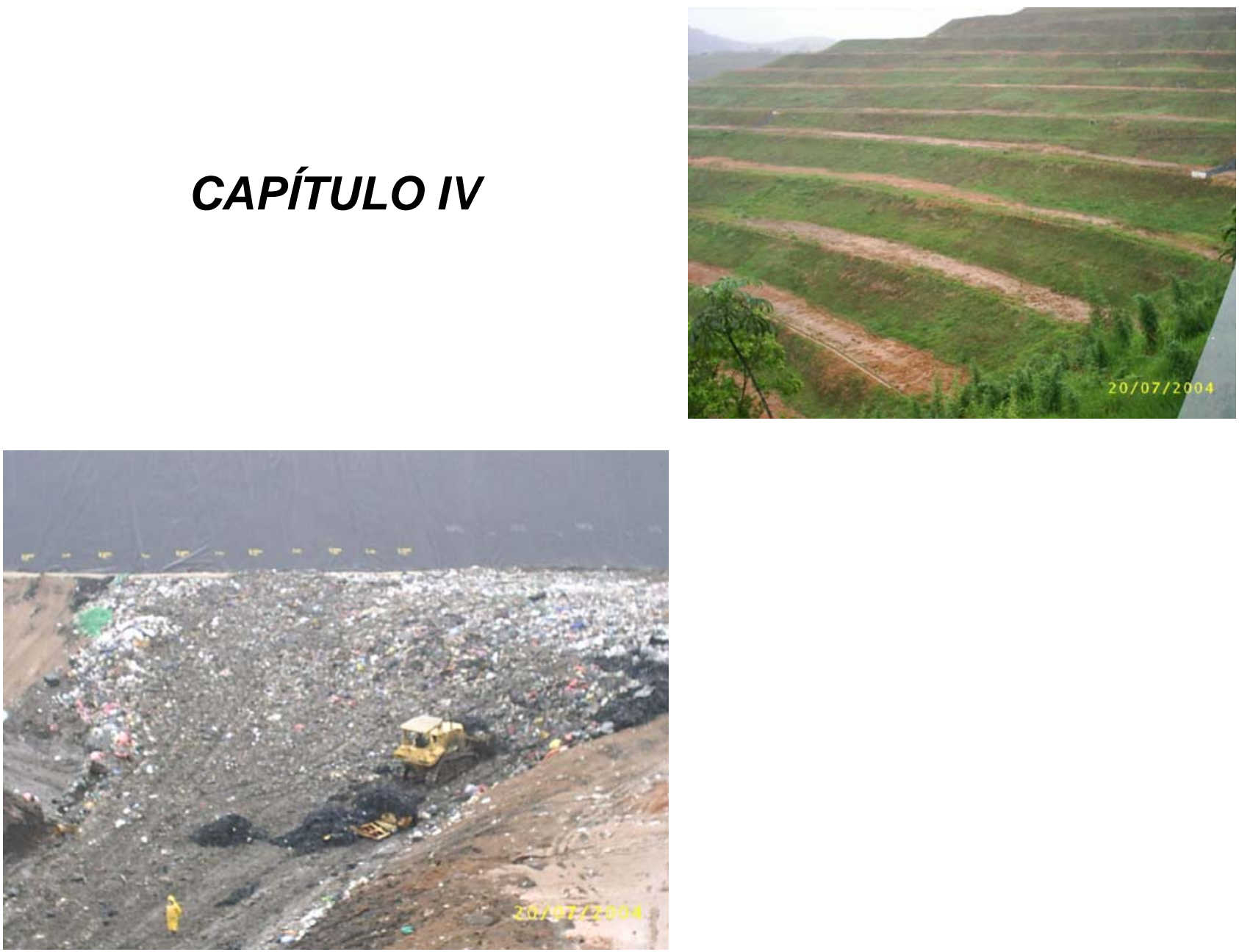

Fotos do Aterro Sanitário da área de estudo 


\section{0 - REFERÊNCIAS BIBLIOGRÁFICAS}

ABETRE- Associação Brasileira de Empresas de Tratamento de Resíduos. (2004). http:// www. abetre.org.br. (29/10/2004).

ABRELPE: Associação Brasileira de Empresas de Limpeza Pública e Resíduos Especiais: Panorama dos resíduos Sólidos no Brasil (2004). Disponível em http://www.abrelpe.com.br. 83 p.

AGENCY FOR TOXIC SUBSTANCES AND DISEASE REGISTRY. (1992). ATSDR

- Toxicological profile for aluminium and compounds. Atlanta, Georgia. 136 p.

AGENCY FOR TOXIC SUBSTANCES AND DISEASE REGISTRY (ATSDR), 1999. Toxicological profile for lead. Atlanta: $587 \mathrm{p}$.

AGENCY FOR TOXIC SUBSTANCES AND DISEASE REGISTRY (ATSDR), 2000. Toxicological profile for Manganese. Atlanta, 504 p.

AGUIAR, M. R. M. P.; VIGNOLI, C. N. (2007). Monitoramento de Parâmetros Ambientais do Processo de Evaporação de Chorume. $24^{\circ}$ Congresso Brasileiro de Engenharia Sanitária e Ambiental. Minas Gerais. 4 p.

ALFREY, A.C. (1984). Aluminium Intoxication. N. Engl. J. Méd. vol. 310, p. 11131115.

ALLOWAY, B.J. (1995). Heavy Metals in soils. Blackie Academic \& Professional. $368 \mathrm{p}$.

ALMEIDA, M.M.F. (1976). The System of Continental Rift Bordering the Santos Basin, Brazil. Anais da Academia Brasileira de Ciências, Rio de Janeiro, n. 48. p. 15-26.

ALVES, J.W.S. (2000). Diagnóstico Técnico Institucional da Recuperação e uso Energético do Biogás Gerado pela Digestão Anaeróbia de Resíduos. Dissertação de Mestrado - PIPGE - Universidade de São Paulo São Paulo. 
AMERICAN PUBLIC HEALTH ASSOCIATION (1995). APHA - American Water Works Association. Water Environmental Federation. 19 ed.

AMOKRANE, A.; COMEL, C.; VERON, J. (2004). Landfill Leachates Pretreatment by Coagulation-flocculation. Tech. rep. Institut national des Sciences Appliquées de Lyon-France.

ANDERSSON, K. et al. (1991). Safe hazardous waste management systems: a state-of-the-art guide for decisions makers. ISWA Working Group on Hazardous Wastes - Series 1991, number 1).

ANDRADE, J. (2001). Tratamento de Percolado de Aterros de Resíduos Sólidos Urbanos Enfatizando o uso de Processos Oxidativos Avançados. Disciplina Processos Oxidativos Avançados no Tratamento de Efluentes PEQ/COPRE/UFRJ.

ANJOS, J.AB.A. (2003). Avaliação da Eficiência de uma zona alagadiça (Wetland) no controle da Poluição por Metais Pesados: o caso de Plumbum em Santo Amaro da Purificação/Ba. Tese apresentada à Escola Politécnica da USP. 301 p.

ARCURI, A.S.A. \& FERNICOLA, N. A.G.G. (2003). Riscos ao Meio Ambiente e Acidentes Relatados. In: METAIS: Gerenciamento da Toxicidade. AZEVEDO, F.A. \& CHASIN, A.A.M. Atheneu Inter Tox 554 p.

ASSOCIAÇÃO BRASILEIRA DE NORMAS TÉCNICAS (1987) - NBR 10157. Aterros de resíduos perigosos - Critérios para projeto, construção e operação. ASSOCIAÇÃO BRASILEIRA DE NORMAS TÉCNICAS (1992) - NBR 8419. Aterros Sanitários - Critérios para projeto, construção e operação.

ASSOCIAÇÃO BRASILEIRA DE NORMAS TÉCNICAS (1997) - NBR 13896. Aterros de resíduos não perigosos - Critérios para projeto, implantação e operação - Procedimento.

ASSOCIAÇÃO BRASILEIRA DE NORMAS TÉCNICAS (2004) - NBR 10004. Resíduos Sólidos: Classificação. 71 p. 
AZEVEDO, F.A. \& CHASIN, A.M. (2003). Metais: Gerenciamento da Toxicidade. São Paulo. Editora Atheneu. 554 p.

BACHE, B.W. (1986). Aluminium Mobilization in Soils and waters. J. Geol. Soc., vol 143, p. 699-706.

BALKAU, F. (1991). Management and control systems for hazardous waste. Paris: UNEP. 28 p.

BATSTONE, R.; SMITH, J. E.; WILSON, D. (1989). The safe disposal of hazardous wastes: the special needs and problems of developing countries. Washington: World Bank, 3 v (World Banck Technical Paper Number 93).

BILA, D.M. (2000). "Aplicação de Processos Combinados no Tratamento de Chorume". Dissertação de Mestrado, PEQ/COPPE/UFRJ. Rio de Janeiro

BILITEWSKI, B; HÄRDTLE, J.; MAREK, K. (1994). Waste management. SpringerVerlag Berlin Heidelberg. 699 p.

BOULDING, J.R. (1995). Practical handbook of soil, vadose zone and gorundwater contamination: assessment, prevention and remediation. New York, CRC Press. Cap. 3, p. 118-156.

BRADY, N. C. (1989). Natureza e Propriedades dos Solos. Trad. Antônio B. Neiva Figueiredo. $7^{a}$ Edição. Rio de Janeiro, Livraria Freitas Bastos. 898 p.

BROOKINS, D.G. (1988). Eh - pH Diagrams for Geochemistry. Springer-Verlag, New York. 176 p.

CALDERONI, S. (1998). Os Bilhões Perdidos no Lixo. $2^{a}$ Edição. São Paulo: Humanitas Editora / FFLCH / USP.

CAMPANHA, V. A. (1994). A arquitetura Deposicional da Bacia de Taubaté, SP: como Subsídio à Delimitação da Zona de Produção Mineral. Tese de Doutorado. UNESP. Vol. I e II.

CAMPOS, J.C.; FERREIRA, J.A.; MANNARINO, C.F.; SILVA, H.R.; BORBA, S.M.P.; (2002). Tratamento do Chorume do Aterro Sanitário de Piraí (RJ) 
utilizando Wetlands. VI Simpósio Ítalo Brasileiro de Engenharia Sanitária e Ambiental. Vitória, ES.

CARDOSO, L.M.N. \& CHASIN, A.A.M. (2001). Ecotoxicologia do cádmio e seus compostos. Salvador. NEAMA: Caderno de Referência Ambiental. 121 p.

CERCASOV, V.; PANTELICA, A.; SALAGEAN, M.; SCHREIBER, H. (1998). Comparative evaluation of some pollutants in the airborne particulate matter in Eastern and Western Europe: two-city study, Bucharest-Stuttgart, Environment Poll., vol. 101, p. 331-337.

CETESB - Companhia de Tecnologia de Saneamento Ambiental (1993). Avaliação hidrogeológica de locais de disposição de resíduos industriais. Cood. GUNTER, M.A.26 p.

CETESB - Companhia de Tecnologia de Saneamento Ambiental (1996). Dimensionamento, Financiamento e Operação de uma Instalação Central de Eliminação de Resíduos Industriais Perigosos. Anais de Workshop. São Paulo.

CETESB - Companhia de Tecnologia de Saneamento Ambiental (1997). Uso das águas Subterrâneas para abastecimento público no Estado de São Paulo. São Paulo. Relatório Técnico. 35 p.

CETESB - Companhia de Tecnologia de Saneamento Ambiental (2005). Amostragem de água superficial e subterrânea.

CETESB - Companhia de Tecnologia de Saneamento Ambiental (2005). Parâmetros para Qualidade de Solo e Água Subterrânea.

CETESB - Companhia de Tecnologia de Saneamento Ambiental (2006). BIOGÁS: Pesquisas e Projetos no Brasil. Org.: FERRER, J.T.V.; Técnico responsável: ALVES, J.W.S. São Paulo, 184 p.

CHANG., Y. Y.; Hwang, K. Y..;(2000). Chemosphere , 41, 1307.

CHRISTENSEN, T.H.; KJELDSEN, P.; STEGMAN, R. (1992). Effects of Landfill Management Procedures on Landfill Stabilization and Gas Quality. In: Christensen, T.H. (Eds.) Landfilling of Waste: Leachate. London, Chapman \& Hall, p. 119-137. 
CHRISTENSEN, T.H.; KJELDSEN, P.; Bjerg, P.L.; Jensen, D.L. CHRISTENSEN, J.B.; Baun, A.; ALBRECHTSEN, h.; HERON, g. (2001). Biogeochemistry of Landfill leachate plume. Applied Geochemistry, 16, p. 659-718.

CINTRA, I.S.; COSTA, B.M.P.; LIBÂNIO, P.A.; CHERNICHARO, C.A.L. (2002). Estudo da Aclimatação de Biomassa Aeróbia na Degradação de Chorume de Aterro Sanitário. In.: Anais do $21^{\circ}$ Congresso Brasileiro de Engenharia Sanitária e Ambiental. João Pessoa, PB.

CONSELHO NACIONAL DO MEIO AMBIENTE (CONAMA) - 2005. Resolução $n^{\circ}$ 357, Decreto estadual 8468/76.

CONSELHO NACIONAL DO MEIO AMBIENTE (CONAMA) - 2008. Resolução $n^{0}$ 396, $13 \mathrm{p}$.

COX, P.A. (1997). The elements on Earth: Oxford University. Press. P. 105-208.

D'AlMEIDA, M. L. O. \& VILHENA, A. (2000). Lixo Municipal: Manual de Gerenciamento Integrado. $2^{\mathrm{a}}$ ed. São Paulo: IPT/CEMPRE. 370 p.

DANIEL, D.E. (1993). Case Histories of compacted clay liners and covers for waste disposal facilities. In: Proc. Of the $3^{\circ}$ International Conference on Case Histories in Geotechnical Engineering. St, Mo., S. Prakash (Ed.). p. 1407-1425.

DEMPSEY, C.R. \& OPPELT, E.T. (1999). Incineração de Resíduos Perigosos: Uma Revisão Crítica. Trad.: SAGABE, M.N. São Paulo. 78 p.

DEZOTTI, M.W. (1997). Processos Oxidativos Avançados. - Parte I. In.: Técnicas de Controle Ambiental em Efluentes Líquidos.

DEZOTTI, M.W.; RUSSO, C. (1997). Técnicas para Caracterização de despejos e Qualidade das águas de Despejo. In: Técnicas de Controle Ambiental em Efluentes Líquidos.

EMBRAPA - EMPRESA BRASILEIRA DE PESQUISA AGROPECUÁRIA (1981). Mapa de solos do Brasil. Serviço Nacional de Levantamento e Conservação de solos. Rio de janeiro, Ministério da Agricultura. 
ENCINAS, A. V. (2003). Estudo da Geração de Biogás no Aterro Sanitário em Campinas-SP. Dissertação de Mestrado da Universidade Estadual de Campinas. $104 \mathrm{p}$.

EZAKI, S. (2004). Íons de Metais Pesados (Pb, Cu, Cr e Ni) associados a Solos de Cobertura de resíduos Sólidos em dois Aterros Sanitários da Região Metropolitana de São Paulo/SP. Dissertação de Mestrado. IGc/USP. 123 p.

FERGUSSON, J.E. (1991). The Heavy Elements in Soils: Chemistry Environmental Impact and Healty Effects. Pergamon Press, UK.

FERNANDES, F. L. (1993). Arcabouço Estrutural e Evolução da Bacia de Taubaté - SP. Dissertação de Mestrado em Geociências de Rio Claro.

FERREIRA, J.A. (2002). Revisão sobre Técnicas de Tratamento de Chorume de Aterros Sanitários e Relatos de casos no Estado do rio de Janeiro.

FERREIRA, J.A.; CAMPOS, J.C.; RITTER, E.; MANNARINO, C. F.; PAULA, A.P.J. (2005). Reestruturação do Sistema de Tratamento de Lixiviado no Aterro Sanitário de Piraí. Anais do $23^{\circ}$ Congresso Brasileiro de Engenharia Sanitária e Ambiental. Campo Grande.

FILIPEK, L.H.; NORDSTROM D.K.; FICKLIN, W.H. (1987). Interaction of acid mine drinage with waters and sediments of West Squaw Creek in the West Shasta mining district, Califórnia. Environ Sci. Technol 21, p. 338-396.

FRESENIUS, W.; QUENTIN, K.E.; SCHNERIDER, W. (Eds.), 1988. Water analysis - a practical guide to physico-chemical, chemical and microbiological water examination and quality assurance. Berlin: Springer-Verlag, 804 p.

FULLER, W.H. (1986). Site Selection Fundamentals for Land Treatment. In: Land Treatment. A Hazardous Waste Management Alternative. US EPA. The University of Texas, Austin. pp. 86-99.

FUNDAÇÃO CEARENSE DE APOIO AO DESENVOLVIMENTO CIENTÍFICO E TECNOLÓGICO (2001). FUNCAP - Rejeitos de Dessalinizadores: Projetos apontam alternativas. Ano $3, \mathrm{n}^{0} 03$. 
GARCIA, I.; DORRONSORO, C.; (2002). Contaminación Del Suelo. Curso: Tecnología de Suelos.

GOYER, R.A., 1987. Toxic and Essential Metal Interactions. Annual Review of Nutrition. Palo Alto, vol. 17, p. 37-50.

GRANT, L.D. ELIAS, R. GOYER, R. NICHOLSON, W. OLEN, H. (1990). Indirect healt effects associated with acidic deposition. Washington, DC, National Acid Precipitation Assessment Progran, 173 p. APUD: WHO, 1997, Environmental Health Criteria, 184 - Aluminium, International Programme on Chemical Safety Geneva, World Health Organization.

HAMADA, J. (1997). Estimativas de Geração e caracterização do Chorume em Aterros Sanitários. In: $19^{\circ}$ CONGRESSO BRASILEIRO DE ENGENHARIA SANITÁRIA E AMBIENTAL. Trabalhos técnicos digitais: CD-ROM. Foz do Iguaçu. HAN, F.X.; BANIN, A.; KINGERY, W.L.; TRIPLETT, G.B.; ZHOU,L.X.; ZHENG, S.J.; DING, W.X. (2003). New approach to studies of heavy metal redistribution in soil Adv. Env. Resarch. 8, 113-120.

HASUI, Y.; PONÇANO, W. L. (1978). Organização Estrutural e Evolução da Bacia de Taubaté. Com. Brás. Geol., n. 30. Recife. Anais, SBG. P. 368-381.

HESPANHOL, I. (2002). Potencial de reuso de água no Brasil: agricultura, industria, municípios, recarga de aqüíferos. RBRH, vol. 07, $\mathrm{n}^{0}$ 04m p. 75-95 out./dez.

HYPOLITO, R. (1980). Criptomelana - Síntese e Estabilidade. Tese de Livre Docência. Instituto de Geociências da Universidade de São Paulo. 160 p.

HYPOLITO, R.; ANDRADE, S.; SILVA, L. H.; NASCIMENTO, S. C. (2008). Alcalinidade - Metodologia para Determinação em Campo. Analytica. Ano 6, $\mathrm{n}^{0}$ 35. p. 52-61.

INSTITUTO BRASILEIRO DE GEOGRAFIA E ESTATÍSTICA (2002). IBGE Diagnóstico Analítico da Situação da Gestão Municipal de Resíduos Sólidos no Brasil. 
INTERNATIONAL PANEL ON CLIMATE CHANGE (IPCC), 1996. Guidelines for National Greenhouse inventories: Reference manual, vol. 3. Disponível em: http://www.ipcc-nggip.iges.or.jp/public/gl/invs6. Acesso em 20/fev./2003.

IWAI, C. K. (2005). Tratamento de Chorume através de Percolação em Solos empregados como Material de Cobertura de Aterros para Resíduos Sólidos Urbanos. Dissertação de Mestrado. UNESP. 222 p.

JIMENEZ, R.S.; Dal BOSCO, S.M.; CARVALHO, W.A. (2004). Remoção de Metais Pesados de Efluentes Aquosos pela Zeólita Natural Escolecita - Influência da Temperatura e do pH na Adsorção em Sistemas Monoelementares. Química Nova, vol. 27, $\mathrm{n}^{0} 5$, p. 734-738.

JORGE, J.A. (1983). Solo: manejo e adubação. $2^{a}$ Edição. Editora Nobel. São Paulo.315 p.

KABATA-PENDIAS, A. (1995). Agricultural problems related to excessive trace metal contents of soil. In: SOLOMONS, W. et al. Heavy Metal: problems and solutions. Berlim, Springer, p. 3-18.

KADLEC, R.H. (1998). Constructed Wetlands for Treating Landfill Leachate. In.: Constructed Wetlands for the Treatment of Landfill Leachates. MULAMOOTTIL, G.; BEAN, E.A.; ROVERS, E. (Org.). Boca Raton, Florida: Lewis Publishers, p. 1732.

KIANG, Y.H. (1977). Total Hazardous Waste Disposal Through Combustion. Industrial Heating. In: Incineração de Resíduos Perigosos: Uma Revisão Crítica. Trad.: SAGABE, M.N. São Paulo.

KJELDSEN, P.; BARLAZ, M.A.; ROOKER, AP.; BAUN, A.; CHRISTENSEN, T.H. (2002). Present and Long-Term Composition of MSW Landfill Leachate: a Review Critical Reviews in Environmemtal Science and Technology, 32(4) p. 279-336.

LEÃO, M.L.G. (1998). Gerenciamento de Resíduos Sólidos Industriais Perigosos: A Problemática da Região Metropolitana de São Paulo. Dissertação de Mestrado do Programa de Pós-Graduação em Ciência Ambiental da Universidade de São Paulo. 160 p. 
LINDSAY, W. L. (1972). Micronutrients in Agriculture. Soil Science Society of America, Inc., Madson, Wisconsin. P. 7-57.

MALAVOLTA, E. (1994). Fertilizantes e seu Impacto Ambiental: Metais Pesados, Mitos, Mistificação e Fatos. Produquímica: Indústria e Comércio Ltda. Centro de Energia Nuclear na Agricultura. Universidade de São Paulo. SP. 153 p.

MALTEZOU, S. P.; BISWAS, A.K.; SUTTER, H. (1989). Hazardous Waste Management. Tycooly: London and New York. 344 p.

MANCINI, F. (1995). Estratigrafia e Aspectos da Tectônica Deformadora da Formação Pindamonhagaba, Bacia de Taubaté, SP. Dissertação de Mestrado. Instituto de Geociências, USP. 107 p.

MANCUSO, P.C.S.; SANTOS, H.F. (Eds.). (2003). Reuso de água. Editora Manole. São Paulo. 579 p.

MANNARINO, C.F.; FERREIRA, J.A; CAMPOS, J.C.; RITTER, E. (2006). Wetlands para Tratamento de Lixiviados de Aterros Sanitários - Experiências no Aterro Sanitário de Piraí e no Aterro Metropolitano de Gramacho (RJ). Revista Engenharia Sanitária e Ambiental, vol. 11, nº 02, abril/junho. P. 108-112.

MARQUES, J. F. (2003). Comportamento de íons Pb, Zn e Cu em área impactada por escória, produto da reciclagem de baterias chumbo-ácido. Dissertação de Mestrado. Instituto de Geociências, USP. 120 p.

MARTINS, J.C.; OLIVEIRA, M.M.; NEVES, M.J.; CARMONA, M.A.; PIRES, F.P.; BICA, J.; RAMOS, T.B. (2005). Salinidade do Solo e Produtividade de Espécies Forrageiras vivazes regadas com águas salinas. II Congresso Ibérico de la Ciência Del Suelo.

MAURICE, C. \& LAGER, A. (1999). Establishing Vegetation in a Pilot Scale Wetland in a Cold Climate Region. Proceedings Sardinia 99. Seventh International Waste management and Landfill Symposium. Italy. P. 231-237

McBEAN, E.; ROVERS, F.; FARQUHAR, G. (1995). Solid Waste Landfill Engineering and Design. USA: Prentice Hall PTR. 
McBride, Murray B. (1994). Environmental chemistry of soils. New York : Oxford Univ. 406 p.

MELLO. F. A.F.; SOBRINHO, M. O.C.B.; ARZOLLA, S.; SILVEIRA, R.I.; NETTO, A.C.; LIEHL, J. C. (1983). Fertilidade do Solo. Escola Superior de Agricultura "Luiz de Queiroz". Universidade de São Paulo, Piracicaba, SP> Editora Novel. 399 p.

MEURER, E. J.; BASSANI, C.A.; SELBACH, P. A. (2000). Poluentes do Solo e do Ambiente. In: MEURER, E.J. Fundamentos de Química do Solo. Porto Alegre. Gênesis, p. 151-174.

MINISTÉRIO DO MEIO AMBIENTE (MMA), 2004 - Secretaria de Qualidade Ambiental nos Assentamentos Humanos: Programa de Proteção e Melhoria da Qualidade Ambiental. Estudo do Potencial de Geração de Energia Renovável Proveniente dos Aterros Sanitários nas Regiões Metropolitanas e Grandes Cidades do Brasil. 270 p.

MORAES, P.B.; BERTAZZOLI, R. (2005). Electro-degradation of Landfill Leachate in a Flow Electro Reactor. Chemosphere, vol. 58, p. 41-46.

MORGAN, J. J.; STUMM, W. (1996). Aquatic chemistry : chemical equilibria and rates in natural waters. $3^{a}$ Edição. Environmental science and technology. 1022 p.

MUNDELL, W. (1989). In: Paoliello, M. M. B.;CHASIN, M. A. A.. Ecotoxicologia do Chumbo e seus compostos. $144 \mathrm{p}$.

NASCIMENTO S. C. (2007). Comportamento de Íons e Sua associação a Resíduos de Indústria Siderúrgica em Manguezal do sistema Estuário de Santos Cubatão/SP. Tese de Doutorado apresentada no Instituto de Geociências da Universidade de São Paulo. 112 p.

NEDELKOSKA, T.V.; DORAN, P.M. (2000). Characteristic of Heavy Metal Uptake by plant species with Potencial for Phytoremediation and Phytomining. Minerals Eng., vol. 13.

NIRS/WISE - World Information Service on Energy \& Nuclear Information and Resource Service. WISE Uranium Project. 2001. The Aitik Tailing dam failure. 
Disponível em: http://www. Antenna.nl/wise/uranium/mdafai.html. Acesso em 29/jan./2002.

NRC: National Response Center. Truck dumping. Disponível em http://www.nrc.useg.mil/truckdumping.htm. Acesso em 30/04/2002.

OLIVEIRA, D. M.; CASTILHOS, A. B. Jr.; NICOLETTI, A. (2003). Classificação de Resíduos Industriais (NBR 10.004): Uma Ferramenta para o Gerenciamento de Resíduos da Indústria Petrolífera. Anais do $22^{\circ}$ Congresso Brasileiro de Engenharia Sanitária e Ambiental. (ABES) p. 175.

OLIVEIRA, M.B. (2001). A Problemática do Descarte de Baterias Usadas no Lixo Urbano. Ministério do Trabalho e Emprego - FUNDACENTRO: Fundação Jorge Duprat Figueiredo de Segurança e Medicina do Trabalho. 128 p.

OLIVEIRA, O. \& MOTA, S. (1998). Caracterização do percolato do lixão de Jangurussu, Fortaleza, Ceará. Revista Limpeza Pública, vol. 48, p. 21-24.

PETERS, T. (1998). Purification of Landfill Leachate with Reverse Osmosis and nanofiltration. Desalination, vol. 119. p. 289-293.

PUGAS, M.S.; MOURA, C. L., NASCIMENTO, S. C., HYPOLITO, R. (2008). Contaminação de solos por íons de metais pesados ( $\mathrm{Cu}, \mathrm{Ni}$ e $\mathrm{Cr}$ ) associados a industrias de galvanoplastia. Trabalho apresentado no XV Congresso Brasileiro de Águas Subterrâneas, Natal.

REINHART, D.R.; AL-YOUSFI, A.B. (1996). The impact of recirculation on municipal solid waste landfill operating characteristics. Waste Manag. And Res., vol. 14, p. 337-346.

RHYNER, C.; SCHWARTZ, L.J.; WENGER, R.B.; KOHRELL, M.G. (1995). Waste Management and Resource Recovery. Lewis Publishers. 524 p.

RICCOMINI, C. (1989). O Rifte Continental do sudeste do Brasil. Tese de Doutorado. Instituto de geociências - USP. São Paulo. 256 p. 
ROBINSON, H. (1993). The Tratament of Landfill Leachate to Standards Suitables for Surface Water Discharge. Proceedings Sardinia 91, Third International Waste Management and Landfill Symposium - Cagliari, Italy, p; 905-917.

ROCCA, A.C.C. et al. (1993). Resíduos Sólidos Industriais. CETESB: São Paulo. $233 \mathrm{p}$.

SALOMONS, W.; FÖRSTNER, U.; MADER, P. (Eds.). (1995). Heavy Metals Problems and Solutions. Springer - Verlag. Berlin Heidelberg. 413p.

SANTANA, C. (2002). A salvação do Sertão: camarão e peixes marinhos são cultivados no semi-árido numa inédita experiência para tirar a população da miséria. Revista Sergipe S/A. Ano 02, $n^{0}$ 18, p. 30-32.

SCHIANETZ, B. (1999). Passivos Ambientais: Levantamento Histórico, Avaliação da Periculosidade e Ações de Recuperação. Curitiba: SENAI, 200 p.

SHEPARD, F.P. (1954) Revised Nomenclature for Depositional Coastal Features. Ameri. Ass. Pet. Geol. Bull., Tulsa. v.36, nº 10, p.1902-1912.

SIENKO, M. J. (1977). Elementos de Transição II. In: SIENKO, M.J.; PLANE, R.A. (Eds.) Química. $5^{\mathrm{a}}$ Ed. São Paulo: Nacional, cap. 21, p. 436-454.

SILVA, A.C. (2002). Tratamento do Percolado de Aterro Sanitário e Avaliação da Toxicidade do Efluente Bruto e Tratado. Dissertação de Mestrado da Universidade Federal do Rio de Janeiro. p. 111.

SILVA, M.R.C. (2002). Estudo de Sedimentos da Bacia Hidrográfica do MogiGuaçu, co ênfase na Determinação de Metais. Dissertação de Mestrado do Instituto de Química de São Carlos da Universidade de São Paulo. 85 p.

SISINO, C.L.S. (1995). Estudo Preliminar da Contaminação Ambiental em àrea de Influência do Aterro Controlado do Morro do Céu (Niterói - RJ). Dissertação de Mestrado - FIOCRUZ.

SISINNO, C.L.S. \& OLIVEIRA, R.M. (2000). Resíduos Sólidos, Ambiente e Saúde. Editora Fiocruz: Rio de Janeiro. 142 p. 
SMITH, S.L., D.D. MacDonald, K.A. Keenleyside, C.G. Ingersoll, and L.J. Field. (1996). A Preliminary Evaluation of sediment Quality Assessment Values for Freshwater Ecosystems. Journal of great Lakes Research 22(3):624-638.

SOARES, P.S.M.; YOKOYAMA, L.; FREIRE, D.D.C. (2005). Transporte de Metais Pesados no Solo no Contexto da disposição de Resíduos Sólidos. Série Tecnológica Ambiental. CETEM: CENTRO DE TECNOLOGIA MINERAL. 44 P.

STENSEN, M. (2000). Chemical oxidation for the treatment of leachate-process comparison and results from full-scale plants. Water Science Technology, vol. 35. p. 249-256.

STRAUS, E.L. \& MENEZES, L.V.T. (1994). Minimização de Resíduos. In: $17^{0}$ Congresso Brasileiro de Engenharia Sanitária e Ambiental. Natal.

STUMM, W; MORGAN, J. J. (1996). Aquatic chemistry : chemical equilibria and rates in natural waters. $3^{\mathrm{a}}$ Edição. Environmental science and technology. 1022 p.

TABASARAN, O. (1982). Abfallbeseitigung und abfallwirtschaft. VDI Verlag, Dusseldorf, p. 280, apud: BIRGEMER, H.G. \& CRUTZEN, P.J. The production of Methane from solid wastes. Journal of geophysical research, vol. 92, $n^{0} \mathrm{D} 2, \mathrm{p}$. 2181-2187. 1987.

TAN, K.H, 1993. Principles of Soil Chemistry. $2^{\mathrm{a}}$ edição. 362 p.

TCHOBANOGLOUS, G.; THEISEN, H.; VINIL, S.A. (1993). Integrated Solid Waste Management. Engineering principles and Management Issues. Irwin Mc Graw-Hill. $978 \mathrm{p.}$

TCHOBANOGLOUS, G.; THEISEN, H.; VINIL, S.A. (1994). Gestión Integral de Residuos Sólidos. 1 ed, vol. 1-2. Madri: Mc Graw-Hill, Inc.

TENÓRIO, J.A.S.; ESPINOSA, D.C.R. (2004). Controle Ambiental de Resíduos In: Curso de Gestão Ambiental PHILIPPI, A.Jr.; ROMÉRO, M.A.; BRUNA, G.C.; Universidade de São Paulo - Faculdade de Saúde Pública, Faculdade de Arquitetura e Urbanismo, Núcleo de Informações em Saúde Ambiental. 
TRIGUEIRO, A. (coord.), 2003. Meio Ambiente no Século 21. Editora Sextavante. Rio de Janeiro. 367 p.

TSAI, C.T. (1997). Electrolysis of soluble organic matter in leachate from landfills. Water Research, vol. 31, p. 3073-3081.

UNITED STATES ENVIRONMENT PROTECTION AGENCY (USEPA), 1991. Air Emissions from Municipal Solid Waste landfills - Background Information for Proposed Standards and Guidelines. Emission Standards Division. EPA-450/3-90$011 \mathrm{a}$.

UNITED STATES ENVIRONMENT PROTECTION AGENCY (USEPA), 1996. A Guide for Methane mitigation Projects: gas to energy at landfills and open dumps. Drafty jan/96 USEPA - Office of air and radiation.

UNITED STATES SALINITY LABORATORY STAFF - USSL Staff (1954). Saline and Alkali Soils. Agriculture Handbook, $\mathrm{n}^{0}$ 60. US Department of Agriculture, Washington D.C.

URASE, T.; SALEQUIZZAMAN, M; KOBAYASHI, S.; MATSUO, Y.T.; SUZUKI, N. (1997). Effect of Concentration of Organic and Inorganic Matters in Landfill Leachat on the Treatment of Heavy Metals in Very Low Concentration Level. Water Science Technology, vol. 78, p. 1-48.

VIEIRA, S.M.M. \& ALVES, J.W.S. 2002. Primeiro Inventário Brasileiro de Emissões Antrópicas de Gases do Efeito Estufa. Relatório de Referência. Emissão de Metano no Tratamento e na Disposição de Resíduos. São Paulo: CETESB, 86 p.

WAMBEKE, V.A. (1981). Calculated soil moisture and temperature regimes of South.

WARMAN, P.R. \& COOPER, J.M. (2000). Fertilization of a mixed forage crop with fresh and composted chicken manure and NPK fertilizer: effects on soil and tissue Ca, Mg, S, B, Cu, Fe, Mn and Zn. Can. J. Soil Sci., vol. 80, p. 345-352.

WORLD HEALTH ORGANIZATION (1981). WHO - Environmental Health Criteria, n.17 Manganese. Geneva. 110p. 
WORLD HEALTH ORGANIZATION (1999). WHO - Concise International Chemical Assessment Document, n.12 - Manganese and its Compounds. Geneva. $42 p$.

WILSON, D. C. \& FORESTER, W.S. (1987). Summary and analysis of hazardous waste management in ISWA countries. In FORESTER, W.S. \& SKINNER, J. H. International Perspectives on Hazardous waste management. London, Academic Press, p. 11-96.

WOO, J.H.; CHOL, M.W.; HAN, K.B.; KIM, C.W. (2000). Simultaneous Organic and Nitrogen Removal from municipal Landfill leachate using an anaerobic-aerobic system.

WOODSIDE, G. (1993). Hazardous materials and hazardous waste management : a technical guide. New York : John Wiley. 383 p.

WORLD HEALTH ORGANIZATION (WHO), 1995. Environmental Health Criteria 165 - Inorganic Lead. Geneva. 300 p.

www.daee.sp.gov.br - acessado em 18 de fevereiro de 2008

www.ibge.gov.br - acessado em 18 de fevereiro de 2008

www.maps.google.com.br - acessado em 07 de abril de 2008

www.tremembe.sp.gpv.br - acessado em 23 de março de 2006

YAKOWITZ, H. Hazardous waste management: an international overview (1985).

Paris. OECD (Conference on National Strategies for Managing Hazardous waste, Melbourne). $80 \mathrm{p}$.

ZULAUF, W.E., 1983. Aperfeiçoamento em sistema de tratamento de resíduos sólidos, conjugado com adaptação de gás bioquímico e recirculação de líquidos percolados - INPI Patente nº PI8302365, São Paulo. 